\title{
Records of the
}

Old Charlton Hunt 


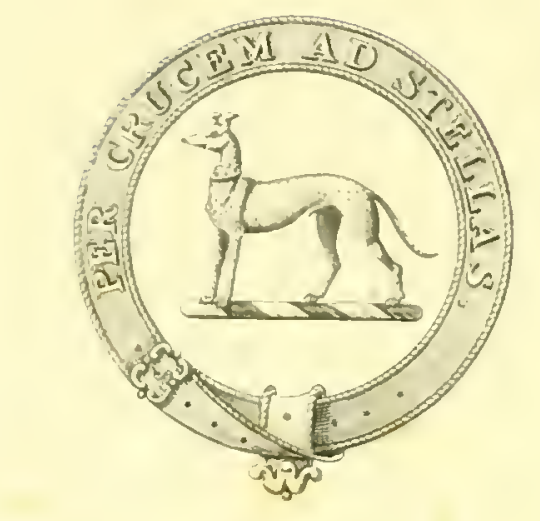

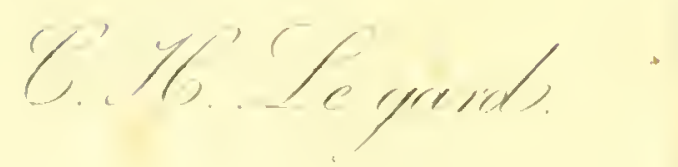




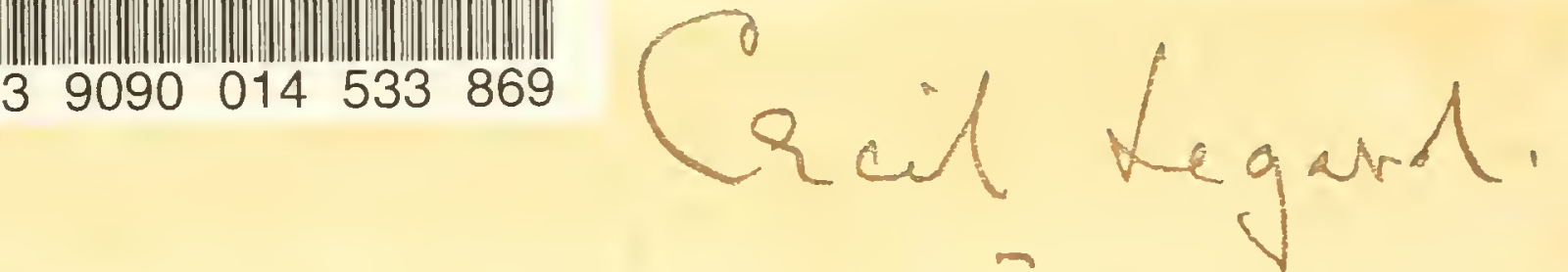

with bestinstes for Jonas x hew Jo ar.

tom

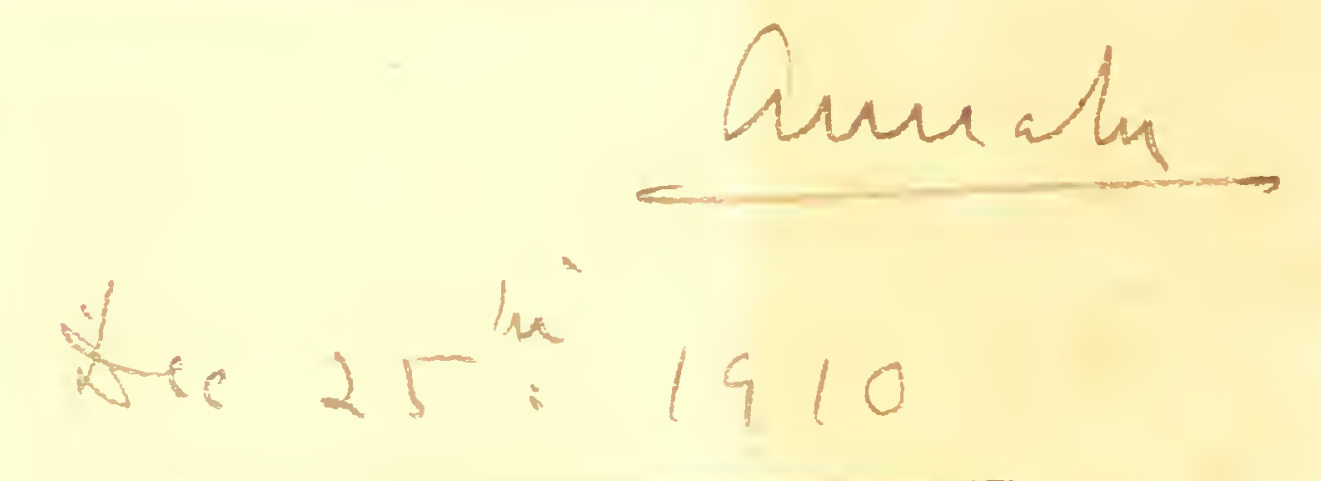

JOHN A.SEAVERNS 



\section{RECORDS OF}

THE OLD CHARLTON HUNT 




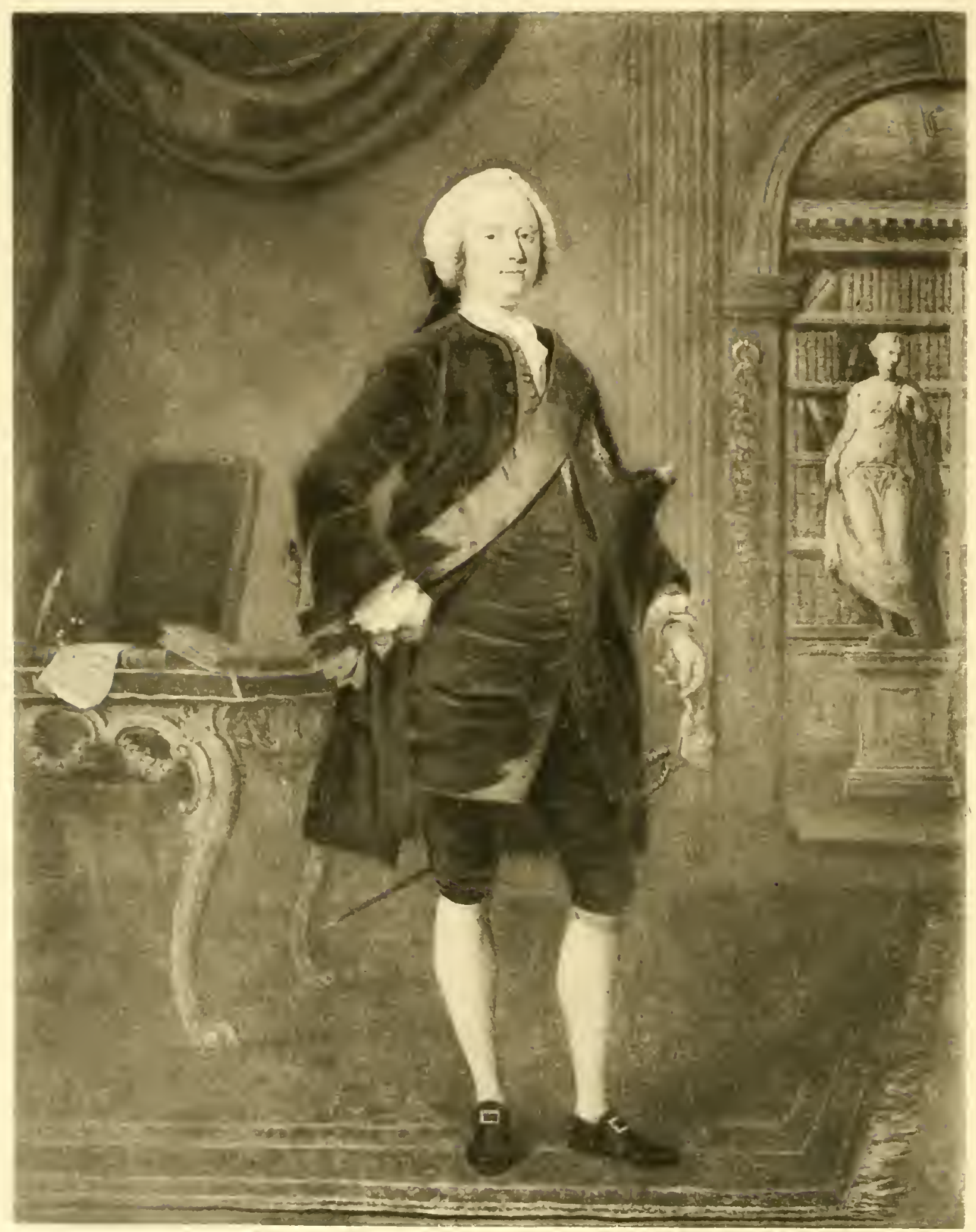

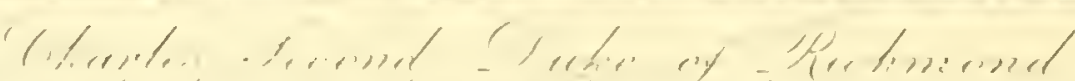

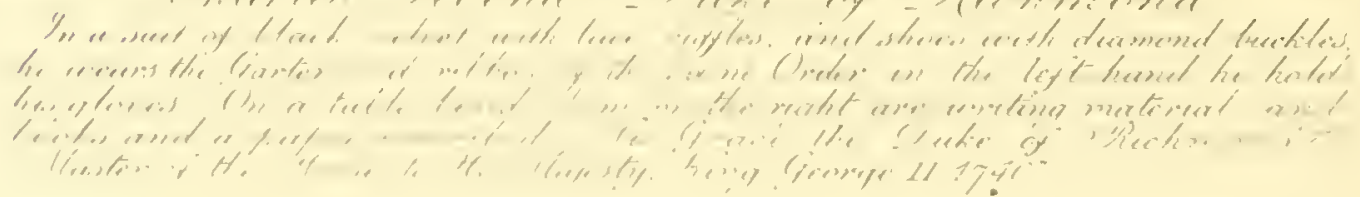




\title{
RECORDS OF THE OLD CHARLTON HUNT
}

\author{
BY \\ THE EARL OF MARCH \\ M.V.O., D.S.O.
}

WITH ILLUSTRATIONS

IN PHOTOGRAVURE, COLLOTYPE, AND HALF-TONE

FROM PICTURES AT GOODWOOD

LONDON

ELKIN MATHEWS, VIGO STREET

M CN X 



\section{AUTHOR'S NOTE}

The text which describes the illustrations (as far as the reproductions of oil-paintings are concerned) is taken direct from the catalogue of Goodwood pictures which was compiled by my mother during the last few years of her life.

And my sincere thanks are due to my friend, Mr. W. J. Roberts, for having so willingly placed at my disposal his skill and knowledge of both indoor and outdoor photography, the results of which appear in these pages. To him, and also to Mr. Elkin Mathews, I beg to tender my complete and grateful appreciation of the interest they have evinced in my venture from the outset, and of the friendly advice (the outcome of their professional knowledge) which has done so much towards lightening my task. 



\section{CONTENTS}

CHAP.

PAGE

\begin{tabular}{llllllll} 
INTRODUCTION & $\ldots$ & $\ldots$ & $\ldots$ & $\ldots$ & $\ldots$ & $\ldots$ & \\
\hline
\end{tabular}

T. Extracts fron Pampilete entitled "Charlton and tue Charlton Hunt"

II. The Agreement between the Duike of Richimond and the Earl of Tankerville touching the hunting of tile $\begin{array}{lllllllllll}\text { COUNTRY } & \ldots & \ldots & \ldots & \ldots & \ldots & \ldots & \ldots & \ldots & 9\end{array}$

III. "The Historicall Account of the Rise and Progress of the Chiarlton Concriess"

IV. Minutes of General Meetings of the Cimariton Hunt .. 39

V. A List of the Duke of Richinond's Hounds _. . 46

VI. Extracts from the Second Duke of Richuond's Hunting Diary, also Toam Johnson's Epitapil in Singleton Cilurcil 52

VII. Hunt Expenses in 1745-1746, etc. .

VIII. Various Hunting Bills of First and Second Dukes of

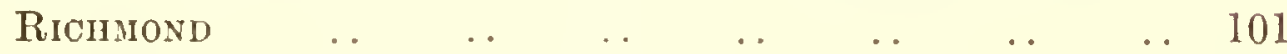

IX. Earl of Tankerville's Instructions .. $\quad \ldots \quad \ldots \quad \ldots \quad \ldots 107$

X. Letters from Sportsmen to Second Duke of Ricmuond .. 109

XI. The 'Sussex Garland'-Hunting Songs $\quad \ldots \quad$.

XII. Anusing Receipts for the bite of a Mad Dog, by Prince

$\begin{array}{lllllllllllllll}\text { RUPERT, ETC. } & \ldots & \ldots & \ldots & \ldots & \ldots & \ldots & \ldots & 172\end{array}$

XIII. ICHABOD 



\section{LIST OF ILLUSTRATIONS}

PAGE

Charles, Second Duke of Rrchuond (Plotogravure) Frontispiece. $\begin{array}{llllllllll}\text { View of Charlton } & \ldots & \ldots & \ldots & \ldots & \ldots & \ldots & \text { to face } & \text {. }\end{array}$

Hunting Agreement between the Dure of Richuond

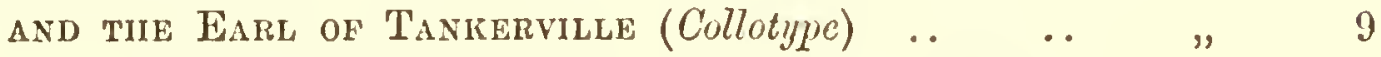

Cifarles, Second Duke of Richiond when Earl of March $\quad, \quad 27$

The Duke's Hunting Box at Charlton . $\quad \ldots \quad \ldots \quad \ldots \quad, \quad, \quad 37$

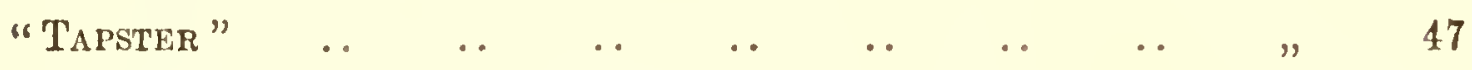

$\begin{array}{llllllllll} & \text { "Gret Carey" } & \ldots & \ldots & \ldots & \ldots & \ldots & \ldots & \# & \end{array}$

"Red RoBIN" .

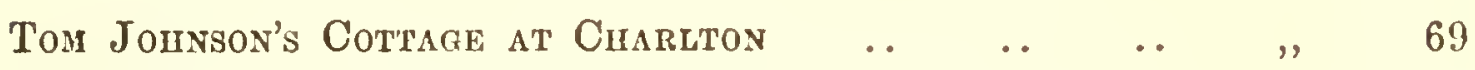

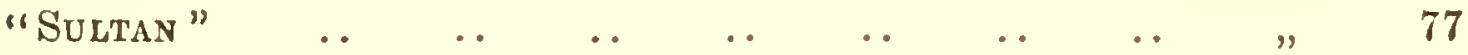

$\begin{array}{llllllllllll}\text { "SHELDON" } & \ldots & \ldots & \ldots & \ldots & \ldots & \ldots & \ldots & \# & 87\end{array}$

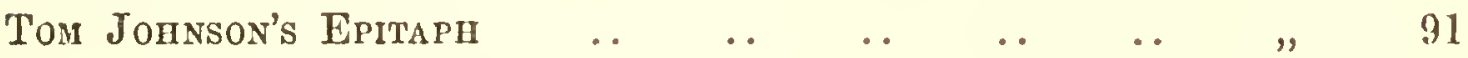

The Fox Inn at Charlton $\ldots$.

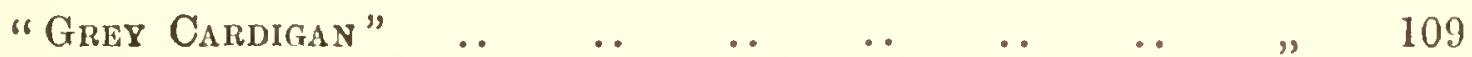

Charles, Second Duke of Ricmond, and Sarafi mis

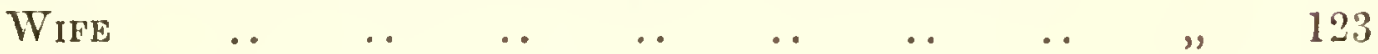

$\begin{array}{lllllllllll} & \text { BAY BoltoN" } & \ldots & \ldots & \ldots & \ldots & \ldots & \ldots & & & \end{array}$ 



\section{INTRODUCTION}

In a deed box at Goodwood there has lain, undisturbed for many years, a bundle of old papers and letters, tattered and discoloured with age, and in some cases almost illegible, but possessing for myself a most absorbing interest, for they represent all that remains to chronicle the forgotten glories of the old Charlton Hunt. And though I feel that the matter contained in them must be of greater interest to local sportsmen than to the hunting world in general, yet I have been tempted to reproduce them as nearly as possible word for word with the originals; for it seemed to me, as I struggled with the queer crabbed writing of the old yellow manuscripts, that the quaint spelling and phraseology would surely have some degree of fascination for hunting men of the present day, many of whom would find constant mention of their forbears throughout these pages.

But had it not been for the assistance given me in my researches by a most excellent and concise little pamphlet entitled 'Charlton and the Charlton Hunt,' published some years ago by Mr. T. I. Bennett, my task would have been much harder; and so, bearing this in mind, I place the said pamphlet before the reader first of all, forming as it does a key to much that follows.

The Agreement betwcen the Second Duke of Richmond $\mathrm{xi}$ 


\section{Introduction}

and the Earl of 'Tankerville, as to the hunting of the country, explains itself. But as an instance of the punctilious care with which matters connected with the "Sport of Kings" were usually conducted in the good old days, I may add that this Agreement is recorded upon a roll of parchment of no less than seven feet in length, signed, sealed, and delivered by both parties in the presence of four witnesses

And so we pass to the 'Charlton Congress,' a curious old manuscript book, on the fly-leaf of which the Duke has made a note to the effect that " this was brought to me by a Porter in the beginning of February 1737."

The writer appears to have remained anonymous ; but it was undoubtedly the work of some local sportsman with a pretty turn for poetry; and notwithstanding the pomposity of the little book, there are passages which must commend themselves to many an M.F.H. and "hound-man" of the present time, for they go to prove that with all his 18thcentury grandiloquence the writer possessed an intimate knowledge of hound breeding and kennel management; so much so, in fact, that we incline to suspect the Duke of having had a fairly shrewd notion as to the identity of the poet, even though he would not give his friend away! And then, in choosing extracts from the Duke's 'Hunting Journal,' arose my chief difficulty. For to me the account of each day's doings proved so engrossing that I was sorely tempted to hand it over in toto to the printer; but the result would have been so excessively bulky that wiser counsels prevailed, and I have confined myself to selecting only a few days out of each of the eight hunting seasons which are recorded so fully in the Duke's handwriting. 


\section{Introduction}

In these days of enormous fields and extensive "capping," the account of the Meeting at which the "Gentlemen of Charlton " formed themselves into a regular Hunt Club, strikes us with a quaint note. For we are told that no stranger might appear in the field unless he had been previously admitted by ballot, at which one black ball was sufficient to exclude; even then his visit was limited to eight days and, should he wish to prolong his stay, a further ballot was necessary! And we learn that a Meeting took place annually, at various London taverns, at which Prosperity to the Hunt and the Memory of Mr. Roper (the founder of the Hunt) were the chief toasts.

The letters written to the Duke by his brethren of the Chace contain, besides the hunting allusions, a sprinkling of topics military, social, and political, many of which, alas, I am quite unable to unravel ; they must remain obscured by the mist of ages as far as I am concerned; but through them all there runs the typical bonhomie and cordiality of the genuine lover of the chace, and it is interesting to note that many of them are written from hunting quarters in the New Forest, whither the gentlemen of Chartton were wont to betake themselves in the spring and autumn, there to follow their favourite pastime, until it was time to foregather once again in that "Great Hall," towards the building of which they had so enthusiastically subscribed.

'The 'Sussex Garland' of hunting songs, composed by a native of Chartton, is copied out of the Hound Pedigree Book, and is verbatim, with the exception of one stanza, which I found it was absolutely necessary to bowdlerize xiii 


\section{Introduction}

before permitting it to appear in public! There is an unfinished appearance about the last one, which leads us to suppose that there was probably a good deal more to follow, but of this there is no trace.

And I think "Lord 'Tankerville's Instructions" deserve a more than passing notice, for the advice contained therein is so sound, notably the one referring to "confabulations down wind," that many a callow sportsman (aye, and full-fledged ones as well) might do very much worse than commit them to memory for future guidance.

And so I offer this scrap-book unreservedly, and without apology for its incompleteness, to all who may care to turn over its pages. For it is indeed a scrap-book, with no pretensions at all to being a complete history of the Charlton Hunt. But it has possibly the saving merit of being original; and if these scanty Records of the good old days afford the reader one tiny fraction of the fascinated interest which I have experienced in compiling and arranging them in some sort of sequence, then shall I be amply repaid for what, after all, has been but a labour of love.

For to me Charlton and "The Forest" possess an oldfashioned and indeed pathetic charm which a stranger can never realise. The landscape and surroundings can have undergone little change since the "Gentlemen of Charlton" made the place the Melton of the age; and as on hunting mornings we wend our way now and again through the little old village, it requires but a small effort of imagination to picture old 'Tom Johnson on that "lowering wintry morn " in January 1738, jogging along the narrow lanes on his way to that historic meet at East Dean Wood, with the 


\section{Introduction}

"glorious twenty-three hounds" clustering sedately round his horse's heels; we can see them return, late at night, those fortunate few, mudstained and weary, but one and all in that state of ecstatic delight which $I$ think fox-hunters alone can feel when they have ridden from start to finish of the greatest hunt of their life-time-of " The greatest Chace that ever was," for thus the Master describes it in his Journal. And then, as the night wears on, we seem to watch them still, those old-time sportsmen, as they gather in the "Great Hall at Charlton." Hark! my friends, to their who-hoops and holloas as they drink again and again to huntsmen, horses, and hounds, but most of all, we like to think, to the memory of that gallant fox that has stood up before them from dawn till dusk!

And then the solemn deliberation, and possibly no little argument (for they are tired, and the port wine is old and potent), as they settle down to the careful selection of the quaint phrases which shall hand down to posterity the "Full and Impartial Account" of this red letter day.

Ah well ! Charlton is very silent now. Honest Tom sleeps sound enough in the neighbouring churchyard of Singleton; dust long, long since are all the gay and gallant company for whom the twang of his horn and his rousing cheer were wont to set every nerve a-tingling with that electric thrill of delight which we, their successors, know and appreciate so keenly; but as we ride slowly home along the broad rides, in the dusk of a winter's evening, we who know the old "Forest" and love it, not only for its own sake, but for the sake of Auld Lang Syne, feel that we have assuredly much to be thankful for in that the "changes and chances of this mortal life" have not as yet succeeded in 


\section{Introduction}

robbing us of the privilege enjoyed by our ancestors two hundred years ago - the privilege of hunting a fox amidst this glorious old world scenery, which, with its varied charms of woodland and open down, can surely have but little rivalry to fear throughout the length and breadth of England. 



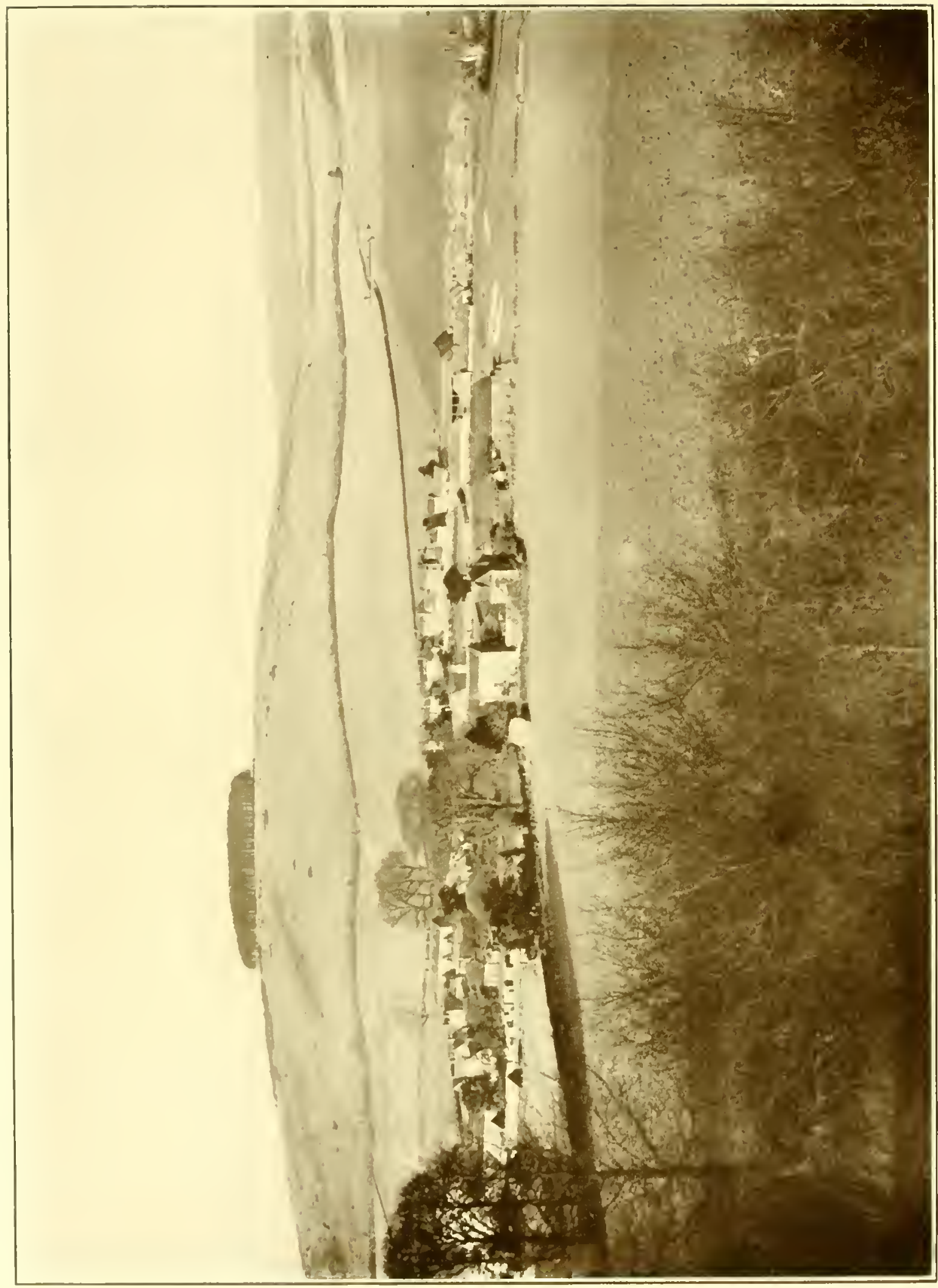

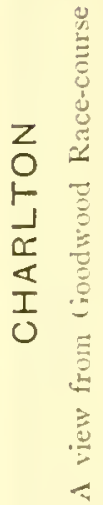




\section{RECORDS OF THE OLD CHARLTON HUNT}

\section{CHAPTER I \\ CHARLTON AND THE CHARLTON HUNT}

\section{A Panphlet written in 1888 by $T$. I. Bennett}

WE have all heard of Goodwood; but where is Charlton? and what of it? A little more than a hundred years ago these questions would have been exactly reversed; then, all the world had heard of Charlton, while the glories of Goodwood, now become a household word among us, slumbered in the womb of time. In an account of the Judges' progress to Chichester in 1749 they are described as being "entertained by the Duke of Richmond, at his seat, near Charlton." The writer evidently either did not know the name of Goodwood, or considered it would give no information to his readers; "near Charlton" was quite sufficient guide as to its locality.

Charlton was the Melton Mowbray of its day, and the Charlton Hunt the most famous in England; the resort of the great and wealthy, eager to participate in our national sport of fox-hunting. King William III. and the Grand 


\section{Records of the Old Charlton Hunt}

Duke of 'Tuscany, then a guest in England, are recorded as having been down to Charlton to witness a fox-chase: and even the softer sex joined in the hunt, held their assemblies in the village, and probably participated in the pleasure of eating a Charlton pie,-a dainty then well known, though now entirely forgotten,--forgotten, as Charlton itself now is: the very traditions have nearly died out; scarcely a villager can now tell of its former renown, or talk of the good old times. But to keep these in remembrance, to commemorate something of the glories of Charlton, the writer of these few pages has collected such information as may interest those acquainted with the neighbourhood, or loving the sport Charlton was so famous for; for much of which he is indebted to the courtesy of Charles Dorrien, Esq., of Adsdean House, who possesses a curious MS. account of the Hamlet and the Hunt.

Charlton, a tything of the parish of Singleton, lies in the valley north of the Goodwood hills, and about a mile east of the high road from Chichester to Midhurst. It is now principally remarkable for its "Forest"-a large wood, extending over 800 acres, belonging to the Groodwood estate, but formerly the property of the Fitzalans, Earls of Arundel, where this great family enjoyed the pleasures of the chase, having a hunting-seat at Downley, on the verge of the forest, of sufficient importance to be used as an occasional residence; indeed, two of the Earls are stated to have died at Downley,-Thomas, in 1525, and William, in 1544 .

From time immemorial, therefore, it appears that the woods and pleasant downs of Charlton have been 


\section{Records of the Old Charlton Hunt}

appropriated to the enjoyment of hunting and the chase; of later years more exclusively to fox-hunting; and from this circumstance only, Charlton derives its celebrity.

As long as the pursuit of the fox has existed as a national sport, it is probable there was a Meet at Charlton; but it was first brought into notice from its being the favourite resort of the unfortunate Duke of Monmouth, who probably owed his acquaintance with Sussex to his friendship with Ford, Lord Grey (afterwards his second in command at Sedgemoor), who was seated at Uppark, in this neighbourhood. Monmouth appears to hare had a peculiar love of Charlton, saying jestingly, "When he was King, he would come and keep his Court at Charlton." So early, too, were his hopes of a future crown alluded to. On one occasion he was so entertained and made much of by the citizens of Chichester, being received by crowds, welcomed by bonfires and ringing of bells, and subsequently taken in state to the Cathedral, that Bishop Carleton thought it necessary to write apologetically to the Metropolitan to excuse the apparent want of loyalty to the reigning sovereign. 'This letter, still extant, is dated February 1\%th, 1679. Amongst those who paid their respects to Monmouth at this time were Mr. Butler, of Amberley, M.P. for Arundel, and his brother-in-law, Mr. Roper, whose connexion with Charlton, as subsequently alluded to, is probably accounted for by this relationship.

Two packs of fox-hounds appear to have been kept at Charlton at this time, belonging to the Duke of Monmouth and Lord Grey, the master and manager being the Mr. Roper before mentioned, a Kentish gentleman, a great lover of the chase, and possessing great knowledge of hounds and 


\section{Records of the Old Charlton Hunt}

hunting. He was sufficiently intimate with Monmouth to be obliged to leave the country on the unfortunate termination of Monmouth's attempt to seize the throne, taking refuge in France, where he made acquaintance with the celebrated St. Victor, and enjoyed in the forests of Chantilly the sport he was debarred from pursuing at home. On the accession of William III., Mr. Roper returned, and resumed the management of the hounds, which appear to have become the property of the Duke of Bolton and himself, and had soon the satisfaction of seeing a noble party of lovers of the chase around him. Among the earliest names mentioned were the Marquis of Hartington (afterwards Duke of Devonshire), whose daring exploit of riding down Leven Down, one of the steepest hills near, and leaping a five-barred gate at the foot, was long remembered; Earl of Halifax, General Compton, Dukes of Bolton and Grafton, Duke of Montrose, Lord Nassau Powlett, Lord William and Harry Beauclerc, Lords Forester, Hervey, Harcourt, and others. How these noblemen were accommodated with lodgings is a wonder to the present generation. Some of them had (probably) built houses of their own,-the Dukes of Devonshire and St. Alban's and Lord Harcourt amongst them; and every cottager, both in Charlton and the adjacent villages, had a lodger in the hunting season: a golden harvest for them. 'To add to the importance of the Hunt, the Earl of Burlington, the Vitruvius of his day, designed them a banqueting-room, where these votaries of Diana feasted after the fatigues of the chase, and talked over the feats of the day. This building was popularly known by the name of Foxhall, from the gilt figure of a fox 


\section{Records of the Old Charlton Hunt}

surmounting a tall flagstaff, erected in front of it, to show the "southerly wind," so dear to fox-hunters, a gift from Henrietta, Duchess of Bolton, the daughter of the Duke of Monmouth, who seems to have inherited her father's love of Charlton. Both she and her youthful son, Lord Nassau Powlett, were constant visitors there.

The fame of Charlton had now reached other countries. St. Victor came from France to return his friend's visit, and both that country and Germany sent admirers of the sport to Charlton, with probably half the aristocracy of England, amongst them the Duke of Richmond, who had purchased Goodwood of the family of Compton in 1720 as a hunting seat, and from thence brought both his Duchess and the youthful Lord March to the meet at Charlton, while her Grace, with her daughter, Lady Ann Lennox (afterwards Countess of Albemarle), held assemblies in the evening at Foxhall, countenanced by the presence of the Duchess of Bolton, Lady Forester, and other ladies whom the attraction of the chase had brought to Charlton,- a love of hunting being by no means confined to the nobler sex.

The success and importance of the Hunt appears now to have provoked the envy of the then owner of Petworth, the proud Duke of Somerset, who, accustomed to be paramount in West Sussex, could not brook the sight of horses and hounds riding over his estate. His Grace's ire is amusingly described as enquiring first of his neighbour, Sir William Goring, of Burton, "Whose hounds they were, so frequently coming near his house?" and on being told they were the "Charlton Pack, Mr. Roper's," cried out, stammering with anger, "Who is he? Where's his estate? What right has he to hunt this country? I'll have hounds 


\section{Records of the Old Charlton Hunt}

and horses of my own," and, in spite of Sir William's remonstrances, had kennels and stables built on the Downs, near Waltham, called Twines (afterwards used by Lord Egremont as racing stables), and even condescended to send down first-rate cooks to tempt the Sussex gentlemen with a sumptuous breakfast; but they were faithful in their allegiance to Charlton, and after a few years' vain endeavour to carry his point, his Grace gave away his hounds, and left the field in disgust.

We have now to record the death of the old Squire, Mr. Roper, who so long had had the management of the Charlton Pack, and had brought it to such perfection: sportsman to the last, he had ridden with the hounds to Findon, but, just at the find, dropped down lifeless on the field, at the advanced age of 84 . By his death, the hounds became the sole property of the Duke of Bolton, who for a short time devoted himself to Charlton; but the attractions of his second Duchess, Lavinia Fenton (the original Polly of the Beggar's Opera), eventually drew him away from Charlton altogether, and on his retirement, he gave the Hounds to the second Duke of Richmond, who assumed the entire management, assisted by Lord Delawarr, and having for huntsman the redoubted Tom Johnson, so well known with the Pack. The Hunt, in their hands, assumed an importance and regularity scarce before known: erery morning a hundred horses were led out, each with his attendant groom in the Charlton livery of blue, with gold cord and tassels to their caps. Lords and Ladies continued to flock to Charlton in the hunting season; and the new Master, the Duke of Richmond, in 1732, built the house, still remaining, where he and the Duchess slept, to be ready 


\section{Records of the Old Charlton Hunt}

for the early meet (eight o'clock in the morning). The walls of the principal room are ornamented with paintings relative to the chase, and stand almost the sole relic of the "Charlton Hunt." About this time occurred that famous Fox-chase, even now remembered in the county of Sussex, lasting ten hours: an event of sufficient importance to cause an account of it to be written and hung up in many of the houses about, where the names of both huntsmen and hounds are carefully preserved.

The Hunt continued to flourish during the life of the second Duke of Richmond; but at his death in 1750, his successor, the third Duke, though a sportsman, was probably not so devoted to the chase as his forefathers. He indeed caused splendid kennels to be built for the hounds at Goodwood; but it is probable that the removal of the Pack from Charlton detracted somewhat from its general popularity, and accordingly we are not surprised to find, in a list of the "Goodwood Hunt," as it was then called, years after, that the members of it were pretty much confined to the county of Sussex. On the fourth Duke of Richmond going to Ireland, as Lord Lieutenant, the hounds were presented to King George IV., and soon after, symptoms of madness showing themselves amongst the pack, they were all destroyed.

So end the glories of Charlton and the Goodwood Pack. Foxhall was pulled down; the residences of the various noblemen in the village have disappeared, (the Duke of Richmond's lodging only remaining), with all vestiges of the Charlton Hunt, once so famous; and the villager, as he hears the distant cry of Lord Leconfield's Hounds occasionally in the neighbourhood, may wonder at those 


\section{Records of the Old Charlton Hunt}

changes in the world which have given to that nobleman, what all the rank and power of his great ancestor could never command,- - the privilege of hunting West Sussex.

Old Harry Budd, of Charlton, gamekeeper to the Duke of Richmond, who died in 1807 , at the age of 94 , was one of the last who remembered, personally, and could talk of the frequenters of Charlton. He had heard his grandfather speak of Monmouth, whom he had conversed with; and Harry had either seen himself, or heard from his grandfather, the names of the following noted personages, as visitors at Charlton:-Duke of Monmouth, Duke of Bolton, Duke of Devonshire, Duke of Kingston, Duke of Montagu, Duke of Montrose, Duke of Grafton, Duke of St. Alban's, Dukes of Richmond, Earl of Pembroke, Earl of Lincoln, Earl of Sunderland, Earl of Kildare, Earl of Dalkeith, Earl of Halifax, Earl Delawarr, Viscount Downe, Viscount Harcourt, Lord Ossulstone, Lord Hervey, Lord Walpole, Lord Ravensworth, Lord Nassau Powlett, Lords William and Harry Beauclerc, Lord Robert Manners, Viscount Dursley, Lord Lifford, Lord Cowper, Lord Bury, Lord John Cavendish, Count La Lippe, Baron Hardenberg, Mr. Watson Wentworth (afterwards Marquis of Rockingham), Hon. I. Dormer, Hon. C. Bentinck, Hon. G. Bennett, Hon. Colonel Waldegrave, Hon. General Brudenel, Hon. John Boscawen, Hon. Captain Legge, Sir Wm. Corbett, Sir Matthew Fetherstone, Sir Cecil Bisshopp, Admiral Townsend, General Honeywood, General Hawley, Mr. Percy Wyndham, Mr. Ralph Jennison (Master of George II.'s Buck Hounds), Brigadier Churchill, \&c., \&c. 

Fip? ?

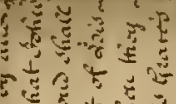

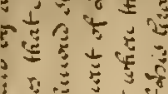

药

उ o s

5. $\because$

कै क 1

$\sigma^{2} \overbrace{}^{2} 5$

列

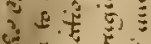

t

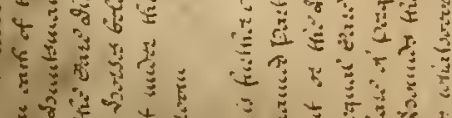

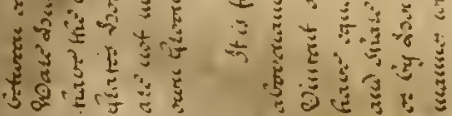

.

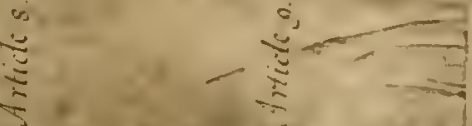

ใด

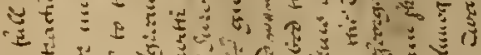

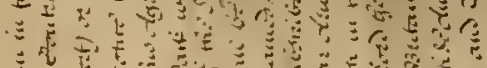

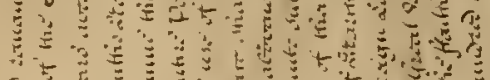

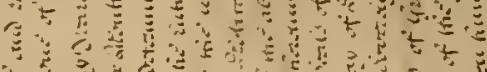

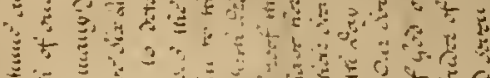

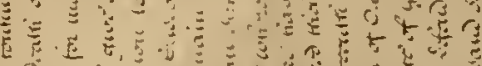

$5 \% 30$

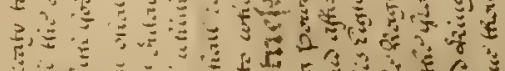

i.

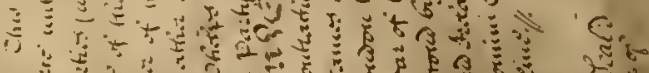

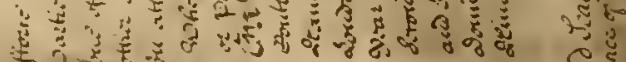

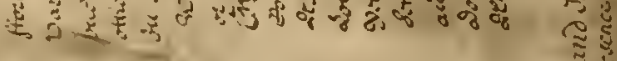
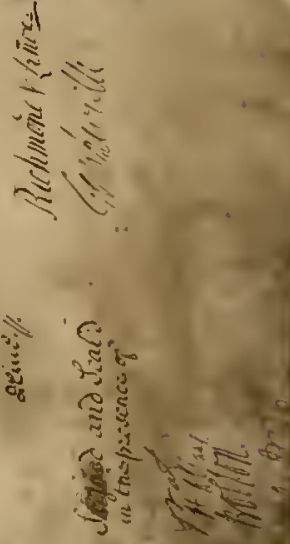
Records of the Old Charlton Hunt 


\section{CHAPTER II}

\section{AGREEMENT BETWEEN THE DUKE OF RICHMOND AND THE EARL OF TANKERVILLE TOUCHING THE HUNTING OF THE COUNTRY}

Treaty of Peace Union and Friendship between the most High Puifsant and Noble Prince Charles Duke of Richmond and Lenox Earl of March and Darnley Baron of Setterington Methuin and Torbolton one of the Gentlemen of His Majesty's Bed Chamber and Knight of the most Noble Order of the Garter and the most Serene and Right Honourable Charles Earl of Tankerville and Baron Ofsulstone of Ofsulstone Concluded at London on the Eighteenth Day of March in the Year of Our Lord One Thousand seven hundred and 'Twenty Nine.

Tubereas the abovenamed most Puifsant and Noble Peers are disposed towards one another with a mutual desire of making Peace and healing now in their own times the Miseries that have of late years wasted and destroyed the County of Sufsex $\mathfrak{J B e}$ it therefore known to all and singular whom it may concern That the most Puifsant and Noble 


\section{Records of the Old Charlton Hunt}

Charles Duke of Richmond and Lenox \&c. and the most Serene and Right Honourable Charles Earl of 'Tankerville \&c. Consulting and providing for (as far as Mortals are able to do) the Advantage Ease and Sport of their Friends as well as the Tranquillity of the said County have resolved at last to put an end to that War which was unhappily kindled and has been obstinately carried on for many years which has been both Cruel and Destructive by reason of the frequent Chases and the Effusion of the Blood of so many vixen Foxes Wherefore the said most Noble and Illustrious Lords (after divers and important Consultations had and held in London for that purpose having at length without the Intervention of any Mediator overcome all the Obstacles which hindered the end of so wholesome a Design have Agreed on reciprocal Conditions of Peace Union and Friendship as follows

Article 1. 'That there be and remain from this Day a True Firm and Inviolable Peace a more sincere and intimate Friendship and a Strict Alliance and Union between the said most Puifsant and Noble Charles Duke of Richmond and Lenox \&c. and the most Serene and Right Honourable Charles Earl of 'Tankerville \&c. the 'Territories they now stand or shall hereafter be pofsefsed of and also their Servants so to be preserved and cultivated that the Parties Contracting may faithfully promote each other's Interest and Advantage and by the best means they are able prevent and repel from each other all Damage and Injury.

Article 2. That a Pack of Foxhounds be maintained by and between the said Charles Duke of Richmond and the 


\section{Records of the Old Charlton Hunt}

said Charles Earl of 'Tankerville which shall consist of Forty Couple at the least.

Article 3. The Earl of Tankerville shall maintain and defray all Expenses relating to the Hounds the Horses of the Huntsmen and Whippers In Warreners Earth Stoppers and all other Contingent Expenses whatsoever relating thereto for the Sum of 'Two hundred and Nineteen Pounds and One Shilling per Annum of Good and Lawfull Money of Great Britain to be paid to the said Earl of Tankerville by the said Duke of Richmond at four equal Quarterly Payments the first Payment to be made on the first Day of August next ensuing the Date hereof.

Article 4. The Duke of Richmond shall be at the Sole Expense of buying Horses for his own Huntsman and Whipper In.

Article 5. 'The Duke of Richmond is to pay the Wages and Board Wages and to furnish the Cloaths of his Huntsman Foot Huntsman and Whipper In.

Article 6. It is moreover Agreed by and between the abovenamed Contracting Powers that the said Pack of Foxhounds shall be kept

ffrom October the $15^{\text {th }}$ to November the $15^{\text {th }}$ at Findon.

ffrom November $15^{\text {th }}$ to January $1^{\text {st }}$ at Charlton.

ffrom January $1^{\text {st }}$ to February $1^{\text {st }}$ at Up Park.

ffrom February $\mathbf{1}^{\text {st }}$ to March $1^{\text {st }}$ at Charlton.

ffrom March $1^{\text {st }}$ to April $1^{\text {st }}$ at Up Park. 


\section{Records of the Old Charlton Hunt}

ffrom April $1^{\text {st }}$ to the laying up the Hounds at Lyndhurst.

ffrom the laying up the Hounds to October $15^{\text {th }}$ at Up Park.

These times of removing the Hounds to be observed unlefs otherwise agreed to by the Consent of both Parties.

Article 7. It is moreover Stipulated and Agreed by and between each of the Contracting Parties that John Ware Huntsman to the Duke of Richmond shall have the Care Direction and Management of His Grace's Horses belonging to the Hunt when they are not under the immediate Care of His Grace's own Groom.

Article 8. It is further Agreed by and between each of the abovenamed Parties 'That John Ware and [*] Vincent or the Huntsmen for the time being shall have equal Care of the Hounds and equal Profits and Share of Perquisites either arising by Field Money or by Hounds that are given away or any other manner whatsoever relating to the Hunt.

Article 9. This Treaty to continue and remain in full Force untill the Death of one of the Contracting Parties (which God for many years avert) or untill one of them shall give Six Months' Notice to the other of his Intention to determine this Agreement In either of which Cases the Entire Pack with the Whelps shall remain to the use of the Survivor or Party to whom such Notice shall be given.

\section{* Christian name unknown}




\section{Records of the Old Charlton Hunt}

In VUditness whereof the abovenamed Contracting Powers have hereunto subscribed their Names and affixed their Seals of their Arms at London this Eighteenth Day of March in the Third Year of the Reign of Our Sovereign Lord George the Second by the Grace of God of Great Britain France and Ireland King Defender of the Faith \&c. Annoque Domini One thousand seven hundred and Twenty Nine.

RICHMOND \& LENOX.

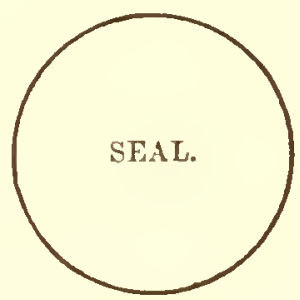

TANKERVILLE.

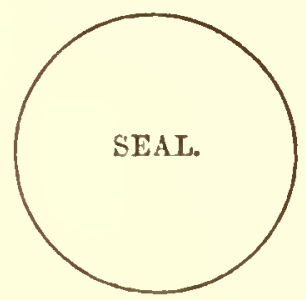

Signed and Seal'd in the presence of

Grafton.

St. Alban's.

Bolton.

Montrose. 


\section{CHAP'TER III}

\section{THE HISTORICALL ACCOUNT OF THE RISE AND PROGRESS OF THE CHARLTON CONGRESS}

Os the fly-leaf of the eurious old manuseript book from which the following poem is taken are written the words :-

"This was brought to me by a Porter in the beginning of February 1737. R."

The note is in the Duke's handwriting, but there is no indication anywhere throughout the Hunt Records as to the authorship of the verses.

They explain themselves. Commencing with a rather flowery description of the surroundings of Charlton, the writer goes on to tell us how the Goddess of the Chase herself selected this locality as an ideal one in which to establish the Headquarters of the Fox-hunting World; how she proceeded forthwith to stock the hills and dales with

"Foxes brought from Northern climes,"

"and Secretly turn'd out, by her command"-

- (rather a shady transaction, one would think, for a Goddess to be mixed up in !)-however, this done, we learn that

"then her thoughts were where to choose her band," 


\section{Records of the Old Charlton Hunt}

and so particular was she in this repect that

"the first firm maxim she laid down was this"

"that blood in ev'ry vein should be the best."

Well, in this the Huntress Goddess saw her wishes carried out to the full; for commencing with the unfortunate Duke of Monmouth there was hardly a single aristocratic family in Great Britain that did not send a representative, at one time or another, to swell the ranks of the "Gentlemen of Charlton," either as a member of that most exclusive Hunt or as an honoured guest of the same.

'The fruitless attempt of the Duke of Somerset (the then owner of Petworth) to outrival the fame of Mr. Roper's pack by establishing one of his own; the consequent breeze that ensued; the death in the hunting field of the old Squire; the abandonment of his farourite pastime by the Duke of Bolton owing to the superior charms of Miss Lavinia Fenton, the celebrated actress, whom he eventually married; the tragic account of that black day upon which Jack Ware, most indifferent of servants and huntsmen, allowed the whole pack to run "amok" and destroy a large number of sheep; all these incidents are dealt with in the Poem, which concludes with a description of the village of Charlton as it appeared when at the height of its glory.

To his Grace the Duke of Richmond, Lenox, and Aubignie, Ec.

\section{Mr LORD.}

The fine Chaces I have seen at Charlton, the Kind and Generous reception I have met with frõyr Grace, and the rest of the Agreeable Company there; tho' an Unworthy 


\section{Records of the Old Charlton Hunt}

Stranger, who never can have it in his Power, to make the Grateful Acknowledgement, which neverthelefs glows in his Plebean Breast.

As it has been my Nightly Dream, so it has been my Dayly talke, and my Study, to Learn as much as I could of the first rise, and long continuance, of the most agreable Society of the kind, that ever was

here it is my Lord, rough, and unhew'n I send it you.

Omissions you'll excuse, the whole you must Despise, but I have eas'd my minde, and have the Satisfaction of taking this Occasion to assure your Grace; with all respect, that no body can be more your Graces

most Obedient

and most Humble

Servt.

Amidst the South Saxonian hills, there runs

a verdant fruitful Vale, in which, at once

fower small, and pretty Villages are seen;

Eastden the one, does first supply the spring,

whence milky Lavant, takes his future course;

Charleton, the next, the beauty of the fower, from twenty chalky rills, fresh vigour adds, then swiftly on, his force redoubled, he thro' all the meads, to Singletown does glide; more Strength, he there receives, at Westden next, his last recruit he makes, then boldly runs, till lef's confin'd, he wider spreads his Fame, and pafsing Lavant, there he takes his Name. he then begins, to do what good he can, during his Short liv'd, 'Transitory reign : 


\section{Records of the Old Charlton Hunt}

here mills for corn, demand his present aid, there Farmers beg! his virtue he'll impart, t' inrich their Lands, for greater future crops. requests all granted, to the Ocean, he as proudly marches, as the greatest of all the confed'rate Rivers of the Land.

In this Sweet Vale, by hills, and Downs enclos'd, an age ago, Diana fixt her Court. her Nymphs, in other Regions she employs; in Softer Chaces, and in Summer Sports. with little Beagles, or her deep mouth'd hounds, on foot they hunt, on mofs, and in the Shade, for pitty twere, to hurt, or tamn a Maid. The British Fiercenefs, to Diana known, the inbred goodnefs, of their Coursers too; like all her Sex, She ev'rywhere would be, ador'd; but how to suit it, with her Chastity? the Country's Beauty, and the Brittish hounds tempted the Goddefs, here to raise her Fame; at last in private, weighing well her Scheme, She thus resolves! I'll be ador'd by men; by Britons bold, where Nymphs shall nere resort, rough is their nature, and they love all sports; a new one, I'll Invent, to fit their 'Taste, their hounds, their horses, and their daring youth; at once I'll suit them, and they'l still do good, the wily Fox, their furious Chace shall be, a small but well chose band, I'll then Select, from all the huntsmen, Britain can produce; and Charleton, is the place, where. I will fix my 'Temple, where my Votarys shall hunt. 


\section{Records of the Old Charlton Hunt}

Charleton, from whence so calld, no record tells, unlefs that Charles of Richmond Duke, by Fate long since determind there at last to come, to grace her Beauty's, with his Pallace Gates, and vye Chantilli, with her Neighbring Woods:

A vast, high Mountain, to the South doe's bear, the Name, of one Saint Roke, unknown elsewhere, a Roman, or a Saxon, Camp 'is trac'd on his high Summit, In the Center there a poste, and Stone well quadrate does appear:

a Lodge of ancient Masons here is held, famous besides, for what did there occurr, the Church was robb'd; what's more, 'twas by a Peer.*

Northward, and riseing close above the Towne, another Mountain's Known, by Leving Downe; a Pirenean path, is Still there seen, where Devons Duke, full Speed, did drive his well bred Courser down, and flying, leap't five barrs ; $\uparrow$ incredible the Acte! but still 'twas fact, but Lo! the next great pointe de vue, the great conspicuous Bow, his bulk so vast, his Length and height, his head so near the Clouds, from Gallias shore, he's plainly seen, and Known; the boldest Land mark, of our British Coast,

* This refers to a hoax perpetrated by the Duke of Richmond upon the Rev. Mr. Sherwin, his chaplain, whom he had robbed by a bogus highwayman when travelling in His'Grace's family coach with the Duchess, who was in the secret.

$\dagger$ 'This is still talked about. 


\section{Records of the Old Charlton Hunt}

with Yews and black thorn, his great Crest is crown'd; green all the winter long, and white in Spring, tis here wise nature, scorning all low Arts, her various beautys, on each side imparts, from Kingly bottom, here the wandring eye, with Southern prospect all the Ocean views; sees all the 'Trade, that passes, to enrich our Brittish Isle, or please Luxurious Tastes; in Peace; tis this, the pleasing prospect yeilds, in Warr; the Dunkirk lurking privateer, hov'ring along the Coast, is seen to Watche like Ren, in warren, how to seize his Prey, But hold, we wander from our first intent, the Rise and progrefs of Diana's Court. The all Directing Groddefs, having viewd the vast Extent of hills, and Dales, that run from East, to west, and all a mofsy turfe, the noted, great, and proper distant woods, and close recesses, here and there disperst, the Badgers earths, where Foxes oft retreat, when hard pursu'd, not trusting to their speed, to each of these, some rustick name she gave, which so Continue to this present Day; by this She meant, to assist her little Court, when warmly Glorying in their Godefs praise; how to report, and how Describe, the Chace. and next, with Foxes brought from Northern Climes, and Secretly turned out, by her Command She Stockt these mossy hills, and Bosquy vales, and then her thoughts, were where to choose her Band; and Such, who would her Laws and rights maintain. 


\section{Records of the Old Charlton Hunt}

A Grosveneur, a name the Norman brought, She thought was requisite to rule the whole; since She, in Decency could not appear.

the first firm maxim, she laid down was this, that blood, in ev'ry vein should be the best; to answer this, the first brave Youth She chose, had graceful mean, with waving locks adornd, but empty head, tho' Sprung from Royal Loins; vigorous he was, and Monmouth was his Name; with him came T[ankervi]lle, Afsociate he, in all his Follys, and his Infamy, how could a Goddefs be so much deceiv'd?

Diana, still unheeding all Events went on, in forming rules of Government, the best bred Hounds of Vermin kind, well known, were all Collected, into one choice Pack; and Horses too, the best of Blood were bought, and all by her Directions, they were chose of middle Size, with Nostrills wide, and Red, the Muzle small, and lean the head, and Jaw, with open throat, no vives along the Chawle, their Crests, and Shoulders thin, their Withers Sharp. too farr, they cant run backward to the Chine, nor can the fillets, be too broad and round, an Oval even croupe, the tail sett high, large ribb'd, close Flank'd, and cushioned well behind his brisket deep, his sides both long, and full, his Joints well knitt, his legs, both flatt and short, his feet, both hard and round, and rather small, than large, for those no speed can ever show; 


\section{Records of the Old Charlton Hunt}

These very rules, she gave to choose her Hounds. All hitherto proceeded well; but Yet, She thought her Pack requir'd some better Skill, Ropero, then She brought, and gave to him the care and management, of all her Mente: He, deep in Knowledge, by Experience taught, could talk upon her Darling Subject well, pleas'd with the Sage, she gave him ample power, to Cast, to cull, to breed, and do his best.

With pleasure great, the Goddefs saw her Court; each day gave Joy, each day encreast their Sport; Bacchus and Ceres, did their Board Supply; and Martha made their Beds, and made their Pye.

But now alafs, confusion seiz'd the Land, And Mars, with malice calls his Sons to Arms: First Monmouth's breast, he with ambition fir'd, to head his Army, soon away he flew, and took, the then thought faithfull 'T[ankervi]lle, along with him, to share his Fortunes all: but Oh! how farr unfit, was Monmouths Skill, to Lead on British Troops, or Seize the Throne: he went, he came, he fought, betray'd, was t'ane; he lost his head; and Cupid lost a Dart. Guiltlefs Ropero too, was forc'd to fly, in those bad days, when Honesty, was Crime. enough, for Jeffrys to pronounce his Doom: to France, then went, the ablest Huntsman here; and made acquaintance, with Saint Victor there 'till William, came, and settled Peace at home 


\section{Records of the Old Charlton Hunt}

Diana Calls, Ropero soon returns;

his Queen as soon declares him Grosveneur.

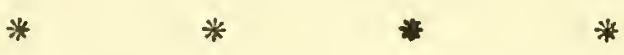

Fame now had loudly Sung, of Charlton Sports, from France, Saint Victor came to see his Friend, the Great 'Tuscanian Duke, too, had been there; William the third, the Great, once saw a Chace.

Hence Jealousy, that gnawing Fiend, began to rouse the Spleen, of a much prouder man, the Second Duke of Brittain, and his Name was Seymour, Somersett, his Title was, his Castle Pettworth, distant three small Leagues, not farr from which, a Worthy Knight there Dwel't, a Sportsman good, as ever Sussex bred, his Castle Hospitable, Burton call'd.

To him the Duke: Sir William who's this Man that dayly, boldly dares, thus in my Sight, to Scower along those azure hills we See? nay, even up to Petworth Walls he comes.

My Lord; Diana's hounds they are; I know Ropero, Good Old man, her Grosveneur. Diana's Grosveneur:- - that place, I'll have. my Lord, a 'Temple She at Charlton has, at Compton too, another still she has, at Findon likewise, does a Temple stand.

with Ire Stamring, his Slaves he loudly call'd; I'll have hounds, I'll have Horses, see't be done; 


\section{Records of the Old Charlton Hunt}

$\mathrm{S}^{\mathrm{r}}$ Knight, Diana's huntsmen we will be, what Land pray has Ropero here, good Sir? where doe his Manors lye? what right has he?

My Lord.-I'me told his Land, in Kent does lye, his Right I doubt the Goddefs will maintain.

The Duke-nor Gods, nor Goddefses, I heed, but Strait a Temple I will raise with Speed, Diana, then may Like it if she please, he Gave the Word; twas done, he call'd it 'Twines, a pretty Spot, and Just upon the Downes, in Stalls magnificent his Coursers lay, in Spacious Kennells, all his hounds did Play, three times a week, he Sent his Cooks ore night, and made a Feast, the Goddefs to appease; for she, to see his Pride was angry growne, and bid her old Ropero keep his grounde.

A Civill warr, of Course was now began, She knew her power, and Stood by her old Man; in Andrews Form, helself was Spy to tell, ere dawn of day appeard, which way he went; then after them, under the wind he drew, and often took their Fox, and Swore 'twas his, had found in such a wood, and ran two hours.

This Discord lasted for some months or more, till one day, when the Knight, the Duke not out, in Friendly manner to Ropero Spoke, Brother, I think we spoile each others Sport; 


\section{Records of the Old Charlton Hunt}

I think so too, but who is most to blame? strong were the arguments on both sides held, the two old Champions both were Loath to Yield; at last, preliminarys strong were drawn, All warr, and future discord, should desist; but soon the haughty Soverains pride rebelld, he gave away his Hounds, and left the Feild.

Now peace returnd, Sir William Joins the Court, All lucky days now blefs their rural Sport, neglected stands the stately 'Temple 'Twine, a Nest for Vermin, or a Stye for Swine.

When now, another Noble Duke [of Bolton] appears, gracefull his Air, and blooming were his years, he long a faithfull votary had been, and paid due homage, to the huntrefs Queen; but now, he begs admittance in her Bande, Fresh Troops he brings, all under his Comand.

Ropero paus'd, but like't the Kind of Hound, which told, he soon the Goddefs willing found; and now they cull each pack, the choicest keep, they found no Fox that ever did escape; for now against poor Ren the odds were vast, at every check two packs there was to cast; John Gough, up wind, did all ways choose to go: but, Harry Barratt, Downe he best did Know.

'Till now, in homely manner they had Liv'd, a small Dark Cell, and one poor Light had servd, 


\section{Records of the Old Charlton Hunt}

to tell the Chace; and sing the Goddefs praise;

till Graftons Duke, and Burlington came down, to see their Sport, so farr beyond their own; then Boyle, by instinct all divine began, is this an Edifice for such a Band?

I'll have the Honour to erect a Room, shall Cost Diana's 'Train, but such a Sum; they all agreed, and quickly paid it down, and now, there stands a sacred Dome [Foxhall], Confes't the finest in the Country, most admird.

And now the Silvan Queen began to think, Recruits would soon be wanting, to her 'Train, young Novices She brought inclin'd to Sport, and plac'tem all under Ropero's care;

to be innitiate in her Rural Rights, and learn of him, the practice of the Field; The Downy N[assau] first she brought, a Youth, well made, and fair Boltona's chiefest care, and then tall W[es]t, of Old Patrician Race, whose warlike Ancestors at Bosgrove lye, this Youth adept, to all he undertook, soon took to hunting, and forsook his Book; the Old Man pleas'd, with so apt a Schollar calld him his Son; and wisht for such another, W-t in return, did all he could to please, he walkt, he talkt, he drefs't, his bootes, his Sleeves, nay more his very shape, was grown like his.

But Lo! the fatal Catastrophe draws near, Ropero, quite worn out with years, tho full 


\section{Records of the Old Charlton Hunt}

in health, yet all his Strength and vigour gone;

at Findon, he and Herbert, Sportsman true, and Andrew, his most faithful Freind, went out to Mountain Furres, fatal was the day!

A Fox just found; gett on he cryes! and then, that Instant fell, and Life that instant fled. and thus Ropero dy'd, at Eighty fower a quick and sudden death, and in the Feild; could Julius Cesar ere' have wisht for more?* B-ns Great Duke, now him succeeds, in all the whole comand of hounds as Grosveneur, the Train encreases, and the Sport goes on, pleasing were all the Delian Virgin's Rules, and happy was great Georges gentle Reign and now Diana's leave first askt, there came, from different parts, Sportsmen of diffrent Names, from Adrians wall, two Nothern Peers there were Montrose-the Duke, and Forester the Lord; with $\mathrm{H}[$ oneywoo]d the Gay, and $\mathrm{K}[\mathrm{ir}] \mathrm{k}$ the Grave, a stripling too, who to the first was kin sedate he was, and sly, and hunting lov'd. as visitors, came full many a one, of Germans, French, and Irish one, to see the Sufsex Sport, or 'tast a Charlton pye. then Graftons Duke, and farming Hallifax, and W[alpo]lls Lord, and D[elawar]r, once W-st, their diffrent Pallaces and, Stables had, the gentle soft and meagre $\mathbf{J}[$ enniso $] \mathrm{n}$, from Humbers banks, on little 'Toby came. G[odolphi]n too, would once essay to see,

* Assuredly not! 



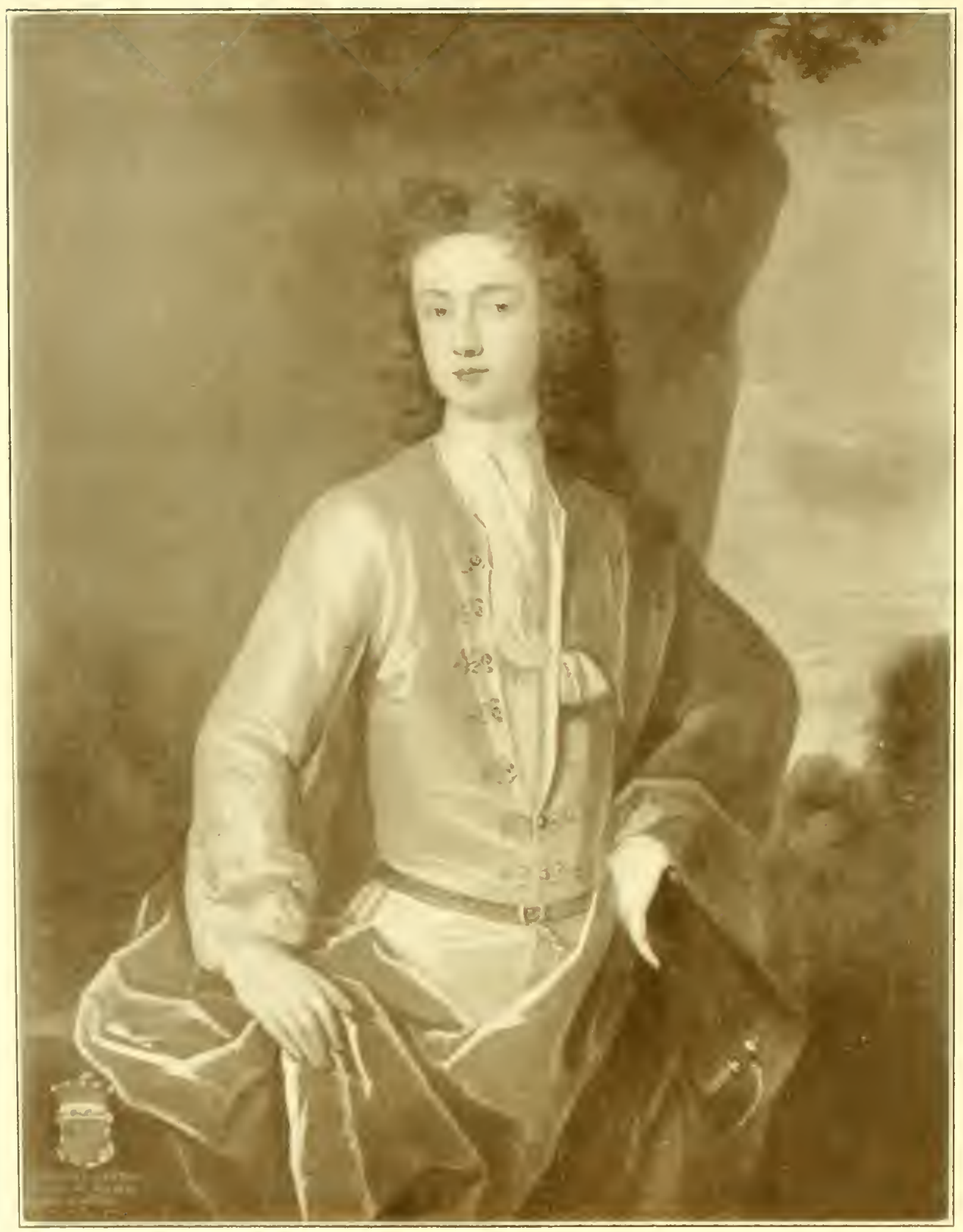

CHARLES, SECOND DUKE OF RICHMOND

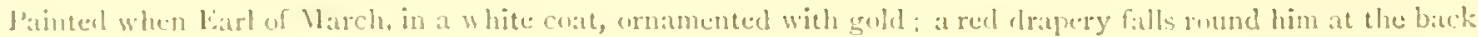




\section{Records of the Old Charlton Hunt}

on foot, for fear; the side hill Chace, the best when winds sett right, and Foxes take that way, and $\mathrm{Ch}[$ urchi]ll-Ch-s best Rider in New Park, for there is Scope, to lay his Courser out; but such as he, the Goddefs did disdain, so gave him back to Venus, and the M[ai]ds. the Ciprian Queen was not content with him, her thoughts, were fixt on Delias choifest man, whose breast, nor she nor Cupid yet had toucht. A Nutt Brown Wench, with Lightning in her Eyes, white Teeth her Beauty, and a warbling voice, outdid herselfe, in acting of Distrefs : admird by all, but most by B[olto]ns Grace; The Queen of Love, who watcht him smild with Joy, he's mine she Cryd, I have him he's my own; long Obdurate, he has my Laws refus'd, but he'll repair that Crime by Constant Love.

Now, he to Charlton for awhile did come, unwilling and asham'd to Leare the Sport; till forc'd at last, by Loves resistlefs power, resignd his place, and Hounds, and left the Court.

Diana vexd, at being thus beguild by venus, and that wicked Imp her boy, resolves to trye how Hymen would agree with early rising, and with long Fatigue; then strait on vigrous Lenox She does pitch, who oft from Goodwood near, did use to come,

* An actress, called Lavinia Fenton (celebrated for her rendering of "Polly Peachem"), whom the Duke of Bolton married. 


\section{Records of the Old Charlton Hunt}

to pay her homage, at her stately Dome; he gladly takes the proferrd place, but begs, that $\mathrm{D}-\mathrm{r}$ sub-Governor may be, to keep her Rights, and Rule, when Absent he, at Aubignie, or Georges Court, must be. consent She Gives, and thus approves his choice; he lov'd Ropero, and Ropero him, In Rufus wastes, he bears despotick sway, where Bolderwood high elevated stands, there in the Spring the hounds shall allways go, there end the Sport, and pleasing dreams retain, while basking in the Summer Sun they Lye.

That Care be his, to see them kept all clean, to view their kennells oft, and see them feed, to register their names, and how they'r bred; that Incest, foule, may never once intrude to spoile the race, and vitiate the Blood, be it likewise his Studyd Care, to choose the proper shape, well bon'd, and wind with Nose, let not thin beauty ever tempt his mind, to make a Nurse of Female kind so shap'd, nor of the males, a Stallion ere to choose, because at head, he once did foremost run; let Just proportion be in both the Rule, what Shapes in this are wrong, let that Amend; in this, Idea Strong, must be his Guide, and trust to nature what she will produce; let crofsings of the Kind be most his Care, for hounds incestous bred, will soon be Currs, nor think, a Steady pack of hounds to breed, 


\section{Records of the Old Charlton Hunt}

because the whelps by steady hounds were gott, the Sexes both, must not with age be worn, a youthful hound of three years old, well try'd for wind and Stoutnefs, and Sagacious nose, when North East wind, or frost exhaled leaves the Tainted Turfe, or Fox got far before, by Cunning turn, the scent by youth orerun, when they do wildly stare, or rattling Fly to every thing they smell, or takes their Eyes; then he, if backward soon he Casts to try, shows innate Judgement, in a hound so young. to him, a wise old Female put, who is at most but six or seven years, well known for finding first, or hitting faults, the same; or to a wise and aged steady hound, in Forreign pack, or in my own remarq'd, his Pedigree, and most of all his nose; to him Conjoin a Bitch of two years old, whose blood, without a Stain long clean has run, altho' no wisdom yet she ere has shown, her projeny will answer all his care, both Strength, and Beauty, thus will they produce, whereas old age, in both will still Deceive his hopes, beware another Error, seen too Oft in many Sportsmen, when their Youth is past; they breed for speed, when they no more can ride, prepostrous thing! a Boy I could forgive.

All hounds while Young too hard are apt to run, they lead with Ignorance, and Burst the rest, who breathlefs come, to mend the faults they make; 


\section{Records of the Old Charlton Hunt}

which done, away again they heedlefs fly, despise the wiser heads of middle age, till off their speed, or foild, with sheep, Unwillingly, submit to them to guide the future Chace, in hopes of getting Blood.

Tis this, with care avoid, tho his great weight, and even yours, should be a reason good; to teach you both, what hounds you ought to breed.

But since Ropero, and his Freind likewise, in this one article did both mistake;

I cant too much enjoyn this future care; remember this, that scenting days are rare,* the reason why, e'en to my selfe unknown, natures dark works, as yet to us untold, consider then what hounds, without good Nose can do, when cold East winds shutt up all pores, nay more, a bright Sun shineing day thats Warm, will cause the same effect, as rising Storms; then Speedy Noselefs hounds will Creep, or Stare, while right bred, vermin, kind will hunt and Stick at Marke, and walke a Fox to death. Nor let him think, tis Shapes alone gives Speed, in hounds, and horses, both his wind does that, tis blood gives wind, proportion Just, the rest; then Stoutnefs Shines, when breathlefs Jades stand still. Consult the Country first, for which you'd breed, for this, or that, must diffrent hounds be bred,

* Too true, and still a mystery, even in these enlightened days. 


\section{Records of the Old Charlton Hunt}

my Sussex hills require short backs, and wind, for no Slight bonelefs baubles those can Climbe.

Early in Spring, let all the puppy's come, winter Starvelings nẽre are worth the rearing, then four or five, he ought at most to keep of every Litter, they the prettiest markt, the Spaniel Colour, or the Brown, reject the Black Tannd Dog, does never take the Eye, the all white hound, of Snowball kind, dont please, the black pyed dog, with bright tannd edges round, with buff, or Yellow head, and white the ground, be this their Colour, they'l by marks be known. Let Countrey walks be got, when once they'r weand, at Butchers, Tanners, Farmers, and such like, where not ore fedd, theyll keep their Shape and grow, and some small knowledge learn, by prouling out. whereas in 'Towns, they'r often fools, or spoild; ten Nurses forty Whelps will raise, each Year, and ten times two, will Scarce supply the pack. In Spring, again, Collecte the Scatter'd youth, in seperate Kennell let them all be clos'd, two Moons at least, and blood them all at first, least madness, mortal bane to all my hounds, shou'd lurking lye, yet hid in their young veins.

And here good Judgement mostly is requird, to choose for bony strength, for shape and size, and all partiallity be then forgott, the Slaves who tend the hounds, may take the rest, the Season past, the Youth be then they'r care, 


\section{Records of the Old Charlton Hunt}

to make them bold, but still obedient too:

to know their names, to come when calld and this

by daily walking out, in Couples Joind;

till Autumn does draw near, the Game yet weak, take out some few, with them, some steady hounds, to find, and guide the yet unknowing Fools; till by instinct, by nature taught, they stoop and know a vermin Scent, for which they'r bred, avoid the Hare. I cannot that approve, 'Tis Sloth in Summer, or want of Game, makes northern Sportsmen argue wrong in that; their Reason's only this, to make hounds Know, when right, when wrong, and mind the Huntsmans rate, my hounds when made no rate at all should hear, it frights the guiltlefs, and baulks the old, conscious they seem, expect the coming lash, at distance humbly creep, or look dismayd; nor anxious more to find, they heedlefs walke behind, and Shew distaste, nor will they beat the thick grown coverts, whose invoven shades the listning Fox conceale; but pafs him by. whereas when hounds no other Scent do know, they'll wind him farr, they'l dash unawd by fear, with emulation fired, they'l drive him out; with vermin Scent inspird, they'l tear their Skins, or loose an Eye, unfelt, whilst in pursuit with eager hast, they force their Thorny way.

November come, another draught must be, he then must cast, the oldest worn out hounds, a thing, ingratefull! yet it must be done, 


\section{Records of the Old Charlton Hunt}

Mars does the same, with old, tho' valliant men.* the young ones too, by this time tryd, and known, which enters not, which cannot run, or tires; away with such, let all be good he keeps, and threescore Couple be at least the Stock, to furnish hounds for thrice a week to Hunt; and thirty couple at a times enough.

Let 'Terriers small be bred, and taught to bay, when Foxes find an unstopt Badjers earthe, to Guide the Delvers, where to sink the Trench; peculiar is their breed, to some unknown, who choose a fighting biting Curr, who lyes and is scarce heard, but often kills the Fox; with such a one, bid him a Beagle Join, the smallest kind, my Nymphs for Hare do use, that Crofs gives Nose, and wisdom to come in, when Foxes earth, and hounds all bayeing stand.

This beagle blood, for this alone allow'd, reject it in the pack in every shape, the Ignorant, who oft have bred too high, do falsly think, the Nose thus to regain, the Crofs is wrong, it alters quite the breed, makes Fox hounds hang, and Chatter, ore the Sccnt, as Vermin blood makes Beagles overrun, the Beagle, for the Hare alone design'd, tho' Foxhounds some so falsly term, when small; if he marks well these hints, he cannot err.

* Vide the War Office List of Officers on Half Pay. 


\section{Records of the Old Charlton Hunt}

Your Slave [Jack Ware], who guides the Pack, I dont approve ;

I have one ['Tom Johnson] in my thoughts, as yet Engaged.

with this I prophecy, some dire mischance, be not dejected, but on me rely.

nor Guides, nor hounds, nor ought, shall wanting be, whole packs I'll send, and that shall be my care;

when Leñox thus, with Heart orejoyd replys,

Goddefs of woods, 'Tremenduous in the Chace,

of Mountain Foxes, and the Savage Race,

my Constant study it shall dayly be,

to mind your orders, and Commands obey, with awful reverence will your rights maintain, with hunting Songs still celebrate your praise.

Near Compton, where Ropero us'd to Hunt, is seen a Castle fam'd for prospect fine, ore sea, and Land, the view does far Extend, Upparke tis calld, thus nam'd from Scite so high: here T[ankervi]lle, the Freind of Monmouth dwelt, and now a Noble Earl, of Stature low, and haughty mein, good humourd tho: when pleasd; this Castle own'd, and the same Title bore, his Youth with Northern Sportsmen he had spent, his Father dead, to Sussex strait he comes, with large Estate, and vigrous youth endued, and hounds he'd have, without the Goddefs leave; this could not please, because twou'd Interfere, Diana soon foresaw, it would not last, She Knew the Youth, so flatterd him a while; 


\section{Records of the Old Charlton Hunt}

at last Contrives, with Lenos he should join, about two years, this Fickle E-le did well; when on a Sudden, he abruptly breaks all Tyes of Freindship, and from Charleton goes; takes halfe the hounds, which chanc't to be the best; while thus distrefsd, the Goddefs vows revenge. another Petty, thoughtlefs, Squire appears, and he foxhounds, and Coursers too, would keep;

Diana soon demolisht all his Scheems, She took away his Pack, and steeds, and all.

but Oh: mishaps! no pleasure, without pain, the fatal accident she had foretold, at last befell her hounds, so much renown'd! that vilest Slave, the Huntsman, Ware, his name; alone, and drunk, went out, and let the Pack kill fourteen Farmers sheep, all in one day; Oh: fatall day! and fatal so the next, now melancholly scences, each Week produc'd, some hounds were hangd, some cast, and still the best; to France some went, where Farmers nere complain; the best thus lost, the rest of little worth, nay Emperor, that fine tho' wicked dog, was all besmeard with blood of harmlefs Sheep; and Luther* too, Killd Lambs, the Shepherds care. Enrag'd at this, the Silvan Queen declares She'l still support her Train, new hounds supply, her fav'rite Lenos, she one night Surprizd, in Husko's $\uparrow$ Shape, she came, and thus she Spoke; ' chear up brave youth, for Fortune smiles on thee.

$$
\text { * See page 51. † Ceneral Huske. }
$$




\section{Records of the Old Charlton Hunt}

' the finest Boy, and noblest post, thou hast;

' the best old huntsman, with no bad hounds I bring,

'accept the present they from Spencer come,

' the youth Oblidges me, and gives them you.

'To Bolderwood then strait repair, and there you'l find 'Tom Johnsons hounds, and D-r, 'There 'Try, and choose the best, and form again a formidable Pack, for Sussex Downs.

'Twas done, the Sport again once more reviv'd, with Transports new, the youth came posting down, to Charlton, where new Sportsmen dayly come, 'To Hunt, to shoot, to Dine at Goodwood some, Goodwood! the place where all exoticks are, from Cooks Exotick, to Exotick Bears ; * but there too, Conjugal Affection Shines, the finest Dutchefs, and the finest Duke, hail happy Matron, hail most happy wife; Still blest, still Lov'd, tho' many years are past, what amorous planett reignd when this fond pair were gott, or born, or happily conjoin'd? the longest honey moon that ever shin'd, and then, their blooming projeny to see; but Emelias $\dagger$ picture who can draw? the pretty'st, prattling poppett ere was seen, petitte 'Tripone, Jollie Mignone des Cieuse, Soiez benite, soiez en toute heureuse.

* The Duke kept a small menagerie at Goodwood.

$\uparrow$ I ady Emily Lennox, afterwards Duchess of Leinster and a celebrated beauty of her time. 



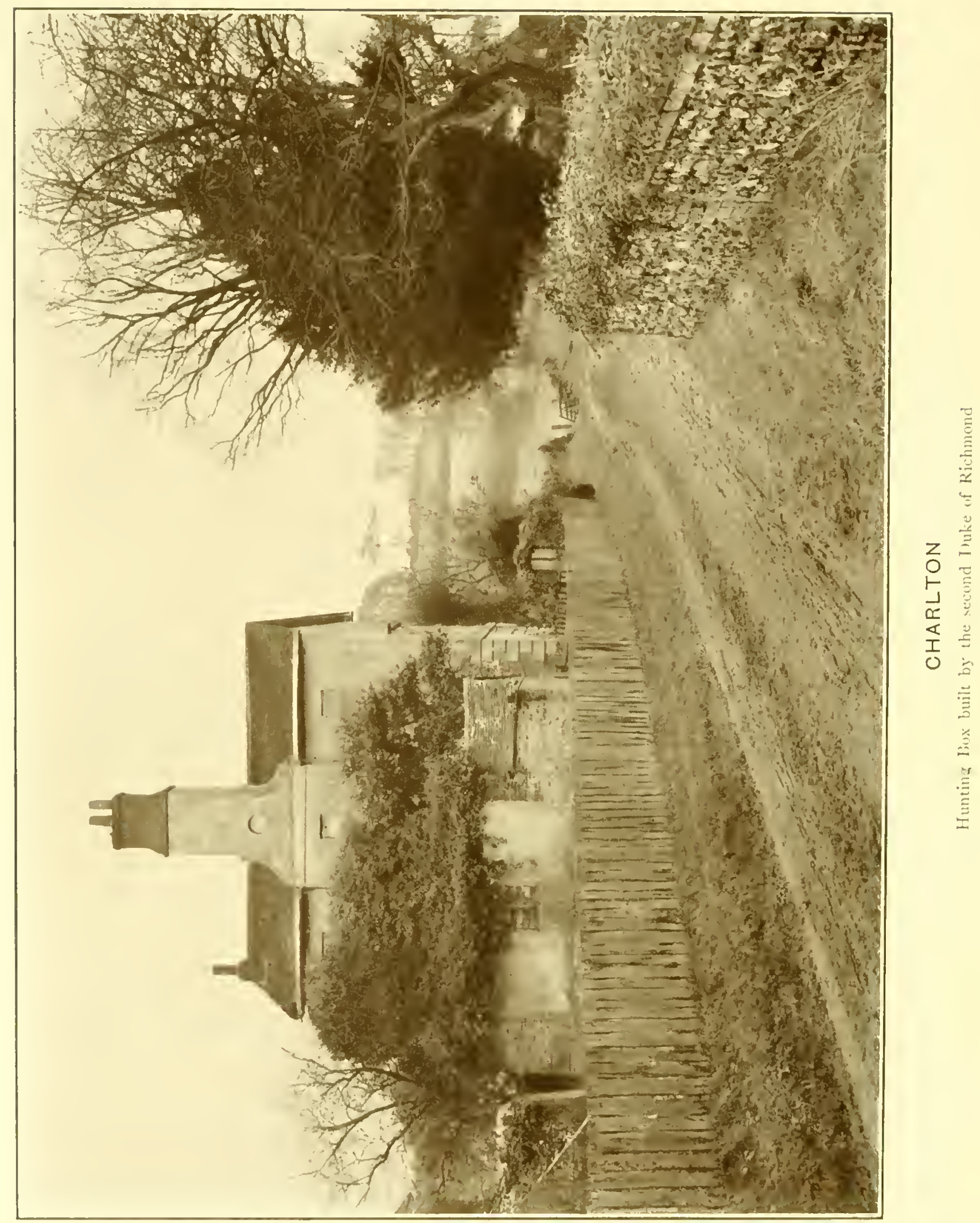




\section{Records of the Old Charlton Hunt}

here Shine the Nymphs, in Amazonian Garbe, by Delia Trusted to Richmond as care, Look how the keen Haralda foremost rides * attended by a Youth on either side.

Fitzw-m, P[embro]ke, now comes cantring on, of Gracefull Stature, this Hibernian Maid, her Size and Limbs for Hercules a Match; some other Nymphs, at sundry times did come, but these their beauty, or Complexion feard, so soon returnd, for softer sports prepar'd.

A hundred speedy Coursers now are seen, by diffrent names they each distinguisht stand in seppr'ate stalls, attended by a Boy, and one Sage Groom, does all those Boys Comande each Sportsman has his stalls, and Groom apart, (who also try's his Master to direct) more regular than formerly was seen, the whole, in every part does now appear; with velvet Caps, in Azure Vests they'r Clad, with Golden loops alike, they all are made, and each for use, wears couples at his side. A warm, but small Apartment, each one has, the Dukes alone appears magnificent, conspicuous it stands [Foxhall], above the rest And uniform, and nearest to the Dome. the Albian Duke[St. Albans], the next best Pallace owns, Just in the Centre of the Village, where in Sacred Spott, white pallizado'd round

* I cannot put a name to this lady. 


\section{Records of the Old Charlton Hunt}

appears a Mast Erect, of Monstrous height, on top of which fly's waving with the Wind, the Emblemattick Standard of the Queen of Woods, whose favrite Colour's always green, in which a Golden running Fox is seen, and near, in verdant Feild inclosd, thro' which the Lavant winding runs, and Lends his aid, to clean three spacious kennells for the hounds, who here all walke, to stretch their Stiffned Limbs, and in this Feild, the Governor resides; from whence he sees the Management of all.

And here a regular Front, full South appears, a double Pallace, which three Freinds did rear, 'The Strong Cavendo [Devonshire] owns the part of one, Fauquier his Freind, in Attick Story Sleeps, young Furious H[arcour]t, did the other build, and great was the Expence and charge of both. Adjoining this a large old Fabrick stands, and three Northumber Youths, in that Do Dwell, then East of this, close by the Lavant side, a certain $\mathrm{Br}$ [igadier Honywood] has built his Hutt, here he, his Slaves, and Strong made Coursers all, with Pompey too, under one 'Thatch do Lye. 'tis thus we're told, the Tartars fierce still dwell, fond of their Horses, of their dogs as fond; some more there are, but not worth remark, where some, as little worth do sometimes come. 


\section{CHAP'TER IV}

\section{FROM THE HUNT PEDIGREE BOOKS, ETC.}

\section{ROPER'S DEATH}

IN the "Hound Book," and quaintly sandwiched in amongst the list of his hounds, appears the old Squire's obituary notice. And yet, perhaps, the place is not so inappropriate, for we are told that his was "a quick and sudden death, and in the Feild"; and surely this grand old sportsman of eighty-four would have wished to have his end recorded in no better fashion than amongst the names of the faithful four-footed friends that were at once the pride and delight of his existence, and the witnesses of his departure for the happy hunting-grounds of which he had so truly earned the right of membership!

\section{$\mathrm{Mem}^{\mathrm{m}}$.}

On the $26 \mathrm{Feb}^{\mathrm{y}}$. $1722 / 3$ being Shrove Tuesday $\mathrm{M}^{\mathrm{r}}$. Roper died att Monckton Furzes. 


\section{Records of the Old Charlton Hunt}

\section{PROPRIETORS OF THE HOUNDS}

1721.-Mr. Roper \& Duke of Bolton.

1722.-Ditto.

1723. - Duke of Bolton alone.

1724. -Ditto.

1725.-Ditto.

1726. - Ditto.

1727.-Ditto.

1728. -Ditto.

1729.-Duke of Richmond \& Earl of 'Tankerville.

1730.-Duke of Richmond, Earl of 'Tankerville, \& Gorton Orme, Esq ${ }^{\mathrm{r}}$.

1731.-Duke of Richmond sole proprietor.

\section{FORMATION OF THE CHARLTON HUN'T (From Hound Book)}

At the General Meeting of the Members of the Charlton Hunt held at the Bedford head Tavern in London. On Sunday January $29^{\text {th }}, 1737 / 8$.

Annual Meeting-Present.

Lord Delawarr, in the Chair.

Duke of Grafton.

Duke of Richmond.

Duke of St. Albans.

Earl of Godolphin.

Earl of Lifford.
Visct. Harcourt.

Lord Hen. Beauclerk.

Lord Nafsau Paulet.

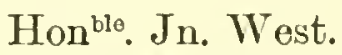

Count Mau ${ }^{c \theta}$ of Nafsau.

$\mathrm{R}^{\mathrm{t}}$. Hon ${ }^{\text {ble. }}$. W ${ }^{\text {in }}$. Conolly, $\mathrm{Esq}^{\mathrm{r}}$.

Sr. Hen. Liddal, Bar?.
Major Gen². Kirke.

Colonel Huske.

Rich ${ }^{\mathrm{d}}$. Honywood, Esq ${ }^{\mathrm{r}}$.

Ralph Jennyson, Esq ${ }^{\mathrm{T}}$.

Edw ${ }^{\mathrm{d}}$. Paunceford, Esq ${ }^{\mathrm{r}}$.

$\mathrm{W}^{\mathrm{m}}$. Fauquiere, Esq ${ }^{\mathrm{r}}$.

Mons $^{\mathrm{T}}$ do Marpon.

The Duke of Richmond proposed to form the Members of this Hunt into a regular Society, which was agreed to 


\section{Records of the Old Charlton Hunt}

Nemine Contradicente \& the following Articles were Resolved on and subscribed by the Members then present and afterwards by the Absent Members, viz.

It is this Day agreed by Us whose Names are hereunto subscribed, that no Person shall be of the Charlton Hunt, who was not an Original Subscriber to the Building of the Great Room at Charlton or a Subscriber to this Agreement unlefs admitted under the following Rules.

$\mathbf{1}^{\text {st }}$. No person to be admitted but by Ballot.

$2^{\text {d. }}$ Any person that is desirous to be admitted a Member of the Hunt must be proposed at Charlton, by one of the Society, and his name affixed up in the Great Room at Charlton, in the Form and manner following, viz. I recommend............to be a Member of the Charlton Hunt. As Witnefs my hand...........

$3^{\text {rd }}$. The person proposed is not to be Balotted for, in lefs than seven Days after his name is affixed up in the Great Room at Charlton; Nor is such Ballot to be by lefs than nine persons of the Society, and the Ballot to be betwixt the hours of Four \& Eight in the Afternoon.

$4^{\text {th }}$. One black Ball is an Exclusion.

$5^{\text {th }}$. No person so excluded to be put in Nomination again that Year.

$6^{\text {th }}$. If any Member of the Hunt is defirous that a Friend may come to Charlton, he must first ask the Consent of Such Members as are at that time at Charlton, which Leave must be obtained by Ballot of the Members then present, if they are not lefs than three in number Provided such person so admitted, does not Stay more than the Space of 


\section{Records of the Old Charlton Hunt}

8 days; and the person so brought down, is to have his Expences defrayed by the Member that recomends him.

$7^{\text {th }}$. If any Stranger is seen in the Field a hunting, he may be invited that day by any of the Company and his Reckoning to be paid by the persons then present.

$8^{\text {th }}$. The Duke of Richmond to bring whoever he pleases from Goodwood to Dinner at Charlton.

$9^{\text {th }}$. Any Additional Article may be made by a Ballot of nine persons, such Ballot to be in the Great Room at Charlton to be determined by the Majority.

$10^{\text {th }}$. If any Dispute arise about the meaning of any of the above written Articles, it shall be decided by the Majority of the Members prefent, at the General Annual Meeting in London.

Names of the Original Subscribers (that are now living) to the Great Room at Charlton.

The Duke of Grafton.

The Duke of Bolton.

The Duke of Devonshire.

The Duke of Newcastle.

The Earl of Carlisle.

The Earl of Burlington.

'The Earl of Litchfield.

'The Earl of Godolphin.

'The Earl of Halifax.

The Ld. Viscot. Lonsdale.

'The Lord Delawarr.
The Lord Lovell.

The $\mathrm{R}^{\mathrm{t}}$. Hon ${ }^{\text {ble }}$. Hen. Pelham.

The Hon ${ }^{\text {ble }}$. Lt. Gen ${ }^{1}$. Compton.

Count Maurice of Nafsau.

The Hon ${ }^{\text {ble }}$. Arth ${ }^{\mathrm{r}}$. Lowther, Esq.

The Hon ${ }^{\text {ble }}$. $\mathrm{S}^{\mathrm{r}}$. $\mathbf{W}^{\mathrm{m}}$. Gage.

The Hon ${ }^{\text {ble }}$. S $^{\mathrm{r}}$. Cha ${ }^{8}$. Wells.

Lieut. Gen'. Honeywood.

Major Gren'. Churchil.

Robert Colvile, Esq. 


\title{
Records of the Old Charlton Hunt
}

\author{
Charlton.
}

Sunday: the $12^{\text {th }}$ of February. 1737/8.

Being the first meeting after the regulating of the Society.

\section{Present.}

Edward Pauncefort, Duke of Richmond.

Esq. in the Chair.

Brigr. Hen ${ }^{\text {ry }}$. Hawley.

William Fauquiere Esq. ask'd the consent of the members present for his brother Francis Fauquiere Esq ${ }^{\mathrm{r}}$. to come down to Charlton for eight dayes

It was accordingly balloted for in the manner Prescrib'd in the sixth Article. And it was agreed to accordingly.

\section{Tuesday 21 Feb. 1737/8.}

Present.

$\mathrm{L}^{d}$. DeLawarr, in the Chair.

D. of Richmond.

D. of St. Albans.

Lord Harcourt.
Brigadier Hawley.

Rich ${ }^{d}$ Honeywood, $\mathrm{Esq}^{\mathrm{x}}$.

$W^{\mathrm{m}}$. Fauquiere, Esq .

$S^{r}$. Henry Liddell.
Sr. Robert Guideford. Edwd. Paunceford, Esq ${ }^{\mathrm{r}}$. Ralph Jenison, Esq ${ }^{r}$. $\mathrm{M}^{r}$. de Marpon.

The following, By Law was proposed and ballotted for and carried in the affirmative.

That any Gentleman of the Neighbourhood or any Gentleman that shall happen to be in the country, may be invited to dinner by any of the Members of the Society. 


\title{
Records of the Old Charlton Hunt
}

\author{
Charlton: Feb. $25^{\text {th }}, 1738 / 9$.
}

Present.

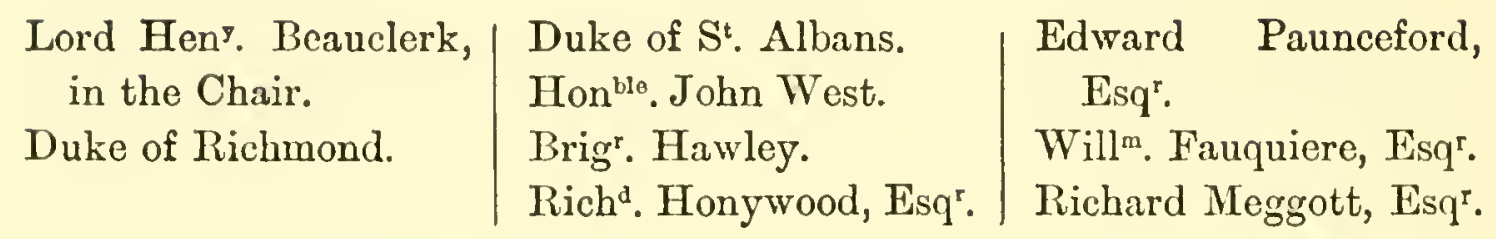

The following by-Law, was proposed, \& ballotted for, \& carried in the affirmative. That every member of the Charlton Hunt that has been at Charlton, any time dureing the hunting season, \& every new member, is to pay his proportion of the extraordinary that year, \& in case the new member does not come, the Person that proposed him, to pay for him.

\section{Charlton: 24 Febry, 1744/5.}

Present.

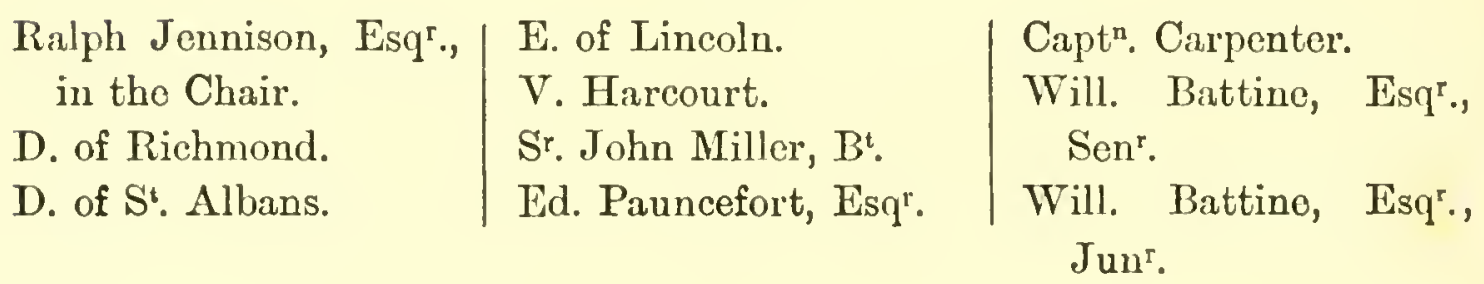

This day The Duke of Richmond proposed that the Earl of Dalkeith should have leave to dine at Foxhall, which upon ballot was granted.

'Then after dinner 'The Earl of Dalkeith was balloted for, \& admitted a member of this Society. 


\title{
Records of the Old Charlton Hunt
}

\author{
At the King's Arms Tavern, Pallmall, \\ Sunday 28 January, 1749/50. \\ Annual Meetivg-Present.
}

Duke of Richmond, in the Chair.

Duke of Grafton.

Marquis of Granby.

Earl of Dalkeith.

Earl of Lincoln.

Earl of Loudoun.

Earl of Home.

Earl of Sufsex.

Earl of Harcourt.

Lord Visct. Bury.

Lord Visct. Trentham.
Lord Visct. Howe.

Lord Visct. Downe.

Lord Robt. Manners.

Lord Delawar.

Lord Chedworth.

Lord Ravensworth.

Hon $^{\text {ble }}$ Will. Keppell.

Hon ${ }^{\text {be }}$. John West.

$\mathrm{Hon}^{\text {ble. }} \mathrm{Col}^{\circ}$. Waldegrave.

Sr. Robt. Smith, Bart.

Adm . Townshend.
$L^{t}$. Gen ${ }^{1}$. Count Luches.

Lieut. Gen¹. Huske.

Willm. Conolly, Esqr.

Ralph Jenison, Esq ${ }^{\mathrm{r}}$.

$W^{m}$. F. S. Paul, Esq.

James Peachy, Esq ${ }^{\mathrm{r}}$.

H. Vane, jun ${ }^{\mathrm{r}}$, Esq ${ }^{\mathrm{r}}$.

G. B. Brudenell, Esq $q^{\mathrm{r}}$.

Cha ${ }^{9}$. Churchill, Esq ${ }^{\mathrm{r}}$.

Cap?. H. Norris.

Edw. Sedgwick, Sẽcry.

Prosperity to Charlton, the Memory of $\mathrm{MI}^{\mathrm{r}}$. Roper, \& several other Healths were drank.

\section{A Motion was made,}

That from and after this $28^{\text {th }}$ day of January $1749-50$, no person shall be ballotted for, to be a Member of this Hunt, according to the $3^{\mathrm{d}}$ Article, that shall be within twenty measured miles of Charlton, at the time of such Ballot, unlefs his Habitation should be within that distance, and in that Case, he may be ballotted for, according to the $3^{\mathrm{d}}$ Article, if he is not within the Village of Charlton, during the time of the said Ballot, nor any time in the day, on which such Ballot is to be made.

And the question being put, it was carried in the Affirmative, nem, contradicente.

and then the Society adjourn'd. 


\section{CHAPTER V}

\section{A LIST OF THE DUKE OF RICHMOND'S HOUNDS}

24 Nov $^{\mathrm{r}}, 1738$

\begin{tabular}{|c|c|c|c|c|c|}
\hline & & By & & & intered \\
\hline $\begin{array}{l}\text { Bonny ... } \\
\text { Buxom }\end{array}$ & $\ldots\}$ & Polewit \& Dashwood & $\ldots$ & $\ldots$ & 1737 \\
\hline Countess & ... & Comfort \& Ratler ... & $\ldots$ & $\ldots$ & 1733 \\
\hline ocker & $\cdots)$ & & & & \\
\hline $\begin{array}{l}\text { Carver... } \\
\text { Careless }\end{array}$ & $\ldots\}$ & Madam \& Trounser & $\ldots$ & $\ldots$ & 1736 \\
\hline Climbank & $\ldots$ & Kindnefs \& Trojan & $\ldots$ & $\ldots$ & 1736 \\
\hline $\begin{array}{l}\text { Cruel } † \ldots \\
\text { Cryer } \dagger\end{array}$ & $\ldots\}$ & Comely \& Ranter ... & & .. & 77 \\
\hline Dashwood & ... & Mr. Orms's Virgin \& old & Jockey & ... & 1734 \\
\hline Drummer & $\ldots$ & Madam \& Mr. Herbert's & Ranter & $\ldots$ & 1734 \\
\hline $\begin{array}{l}\text { Diamond } \\
\text { Emily ... }\end{array}$ & $\ldots$ & Comfort \& D. Rutland's & Limner & & 734 \\
\hline Emperor & $\ldots$ & Orms's Virgin \& old Jocl & key & $\ldots$ & 1734 \\
\hline Emperor & $\cdots$ & D & & & 7 \\
\hline Edmund $\dagger$ & $\ldots\}$ & & $\cdots$ & $\cdots$ & 7 \\
\hline Gillian ... & ... & Madam \& Tapster... & $\ldots$ & $\ldots$ & 1733 \\
\hline Gamester & ... & Lovely \& Jockey ... & $\ldots$ & $\ldots$ & 1733 \\
\hline Kitty ... & ... & $\begin{array}{c}\text { Comely \& Ranter ... } \\
46\end{array}$ & $\ldots$ & $\ldots$ & 1737 \\
\hline
\end{tabular}





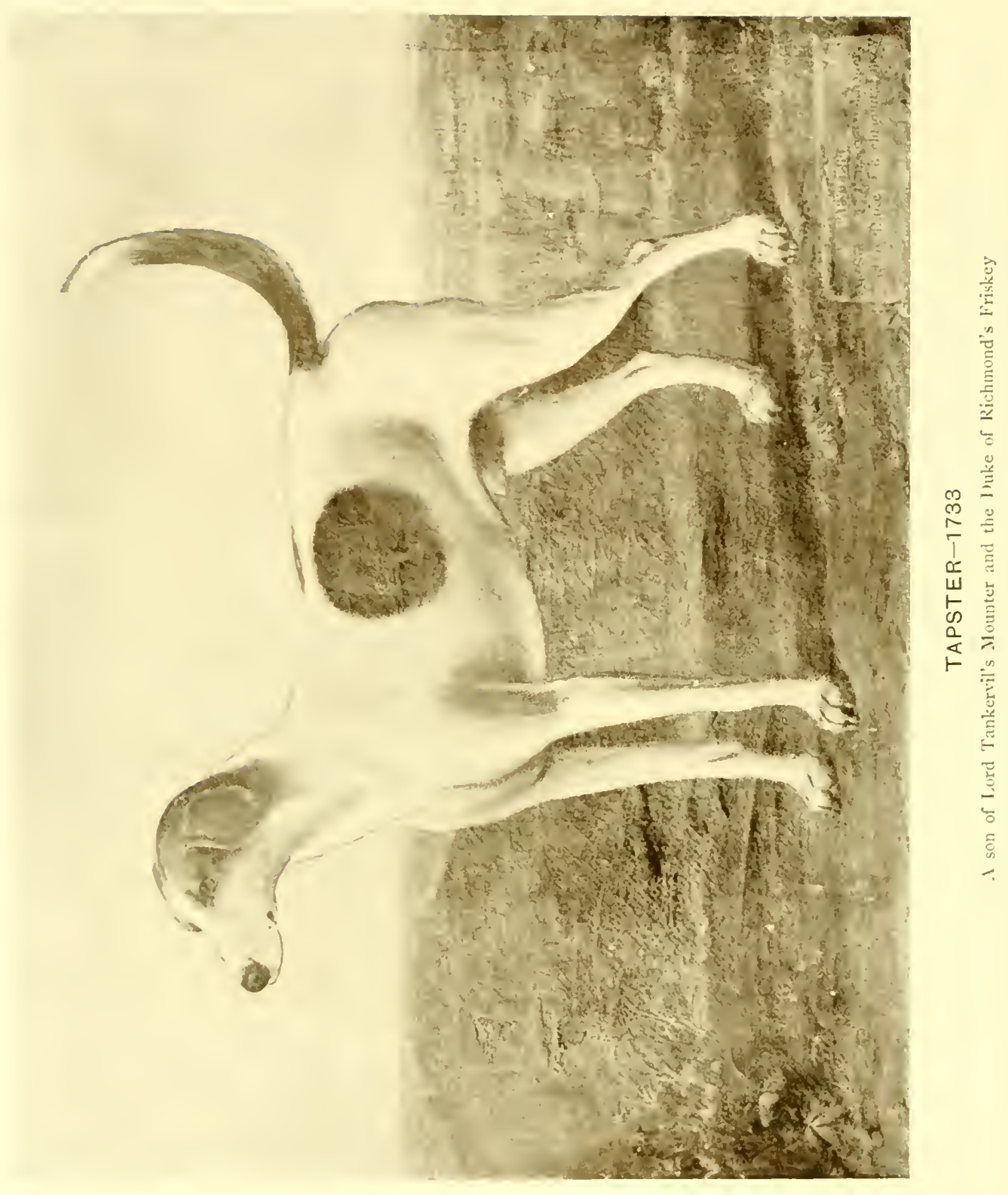




\section{Records of the Old Charlton Hunt}

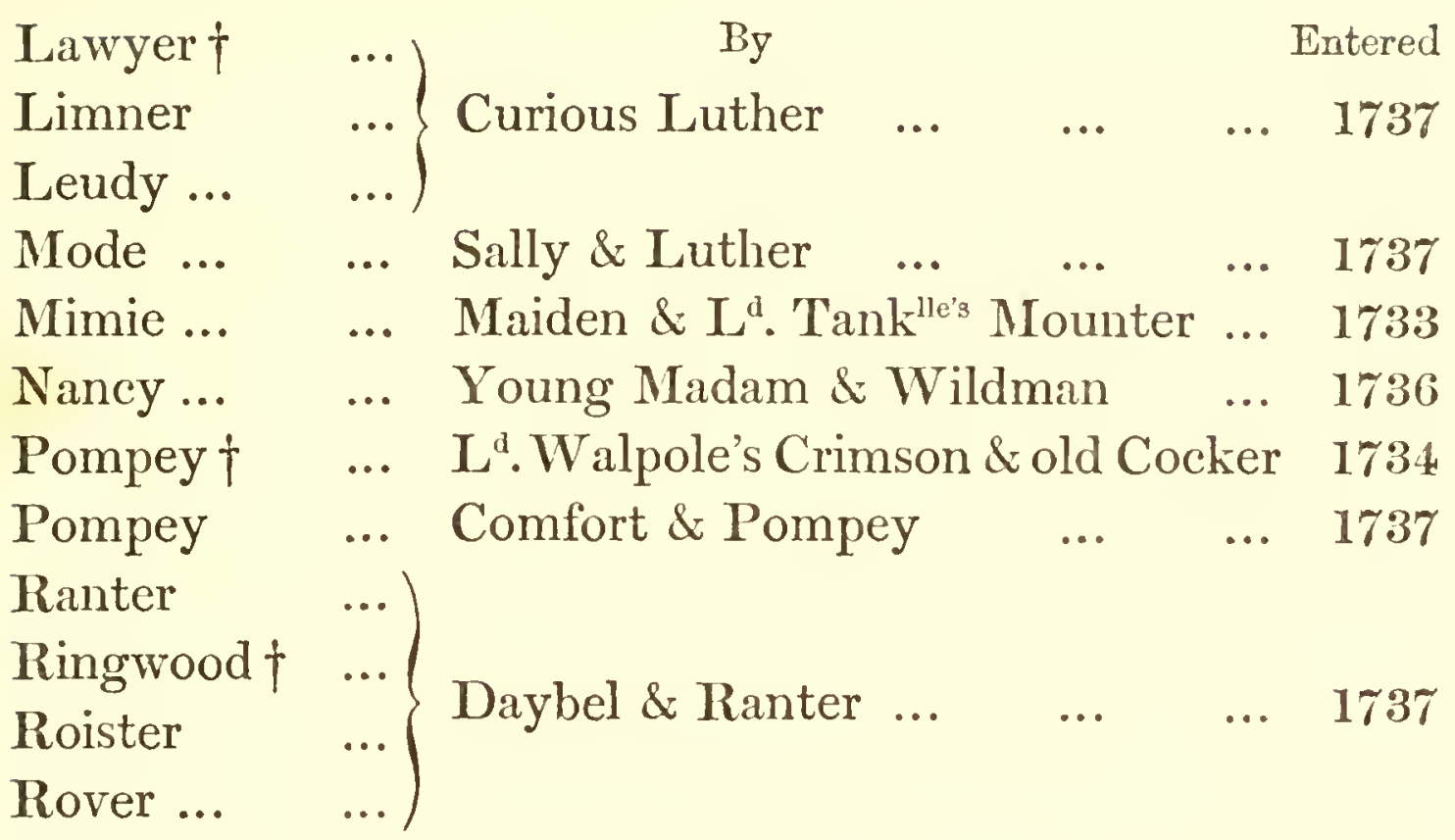

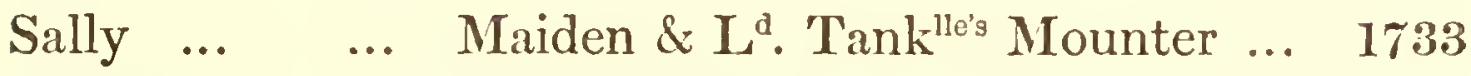

$\begin{array}{llllll}\text { Singwell } \quad \ldots & \text { Emily \& Gamester } \quad \ldots & \ldots & 1736\end{array}$

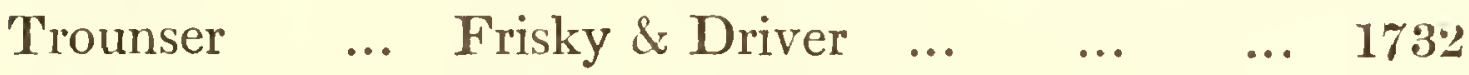

Tantivy $\quad \ldots$ Madam \& $\mathbf{M}^{\mathrm{r}}$. Herbert's Ranter ... 1734

Tipler ... $\quad \ldots \quad$ Sally \& Luther $\quad \ldots \quad \ldots . \quad \ldots \quad 1736$

Tosser ... ...

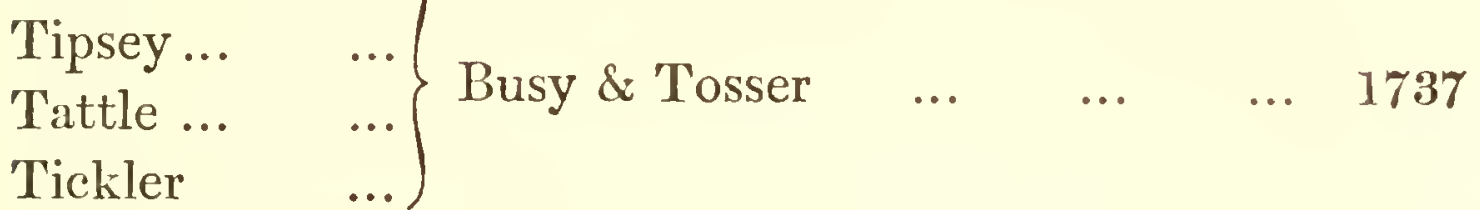

$\begin{array}{llllll}\text { Traveller } \dagger \quad \ldots & \text { Emily \& Trounser ... } & \ldots & \ldots & 1737\end{array}$

Veny $\uparrow \ldots \quad$... Cruell \& L $\mathrm{L}^{\mathrm{d}}$. 'Tank ${ }^{\text {llle's }}$ Mounter $\ldots 1732$

Victor ... $\quad \ldots \quad$ Comfort \& M $^{\mathrm{r}}$. S S $^{\mathrm{t}}$. John's Ranter $\quad 1736$

The above twenty one Couple \& half were bred by the Duke of Richmond.

Careless $\quad$... Minion \& Thumper.

Cruel ... $\quad \ldots \quad \mathrm{S}^{\mathrm{r}}$. $\mathrm{W}^{\mathrm{m}}$. 'Twisden's Sempstress \&

Mounter. 


\section{Records of the Old Charlton Hunt}

By

Comely $\quad \ldots \quad M^{r}$. Pelham's Drinkwell \& 'Trounser.

Cresar ... $\quad$... Bridget \& D. Richmond's Cocker.

Drummer $\quad \ldots$ Nelly \& D. Richmond's Wildman.

Daybel ... $\mathbf{M}^{\mathrm{r}}$. Pelham's Drinkwell \& $\mathrm{D}$.

Richmond's 'Trounser.

$\left.\begin{array}{ll}\text { Doxey } \dagger & \ldots \\ \text { Dido } \uparrow \ldots & \ldots\end{array}\right\}$ Madam \& Mounter.

Finder ... ... Nancy \& Mounter.

Madam _.. Old Bonny \& D. Hamilton's Jugler.

Merry lass _.. Nelly \& D. Richmond's Wildman.

Musick $\dagger$

Nelly ...

.... Cruell \& Ruler.

Pleasant $\quad$... Sempstress \& Tipler.

Ruler ... $\quad$... Nelly \& D. Richmond's Wildman.

Ransom ... Fairmaid \& T. Johnson's Conqueror.

Ringwood _.. Betty \& D. Richmond's Luther.

Singwell $\quad \ldots$ Pallas \& Mr. Withers's Snowball.

Gillian ... $\quad \ldots \quad M^{\mathrm{r}}$. Withers's Molly \& $\mathrm{L}^{\mathrm{d}}$. Craven's

Crowner.

Topper $\quad \ldots \quad M^{\mathrm{r}}$. Morley's Dainty \& Clouder.

Thunder $\quad \ldots$ Old Bridget \& Morley's Victor.

The above nine Couple and half were given by Lord Tankerville in 1737.

Busy $\quad \ldots \quad \ldots \quad$ From Mr. Noel's.

Bowler... $\quad$... $\quad$ L. $^{\mathrm{d}}$. Craven's Bridget \& Warriour.

Crowner $\quad \ldots \quad L^{\mathrm{d}}$. Craven Crowner \& $\quad \mathbf{I}^{\mathrm{r}}$. Andrew's Musick. 


\section{Records of the Old Charlton Hunt}

By

Dido $\quad . . \quad \quad \ldots \quad$ Mr. Andrew's Juno \& L L $^{\circledR}$ Griffin's

Cryer.

Flurry... $\quad \ldots \quad$ Conqueror \& $\mathrm{MI}^{\mathrm{r}}$. Andrew's Juniper.

Gaylass $\quad \ldots \quad \mathbf{M}^{\mathrm{r}}$. Andrew's Fairmaid \& Mr. Noel's Puler.

Lucy ... $\quad$... L $\quad$ L . Cardigan's Wonder \& a Dog of Mr. Newby's.

Mopsey $\quad$... From Mr. Andrews.

Peggy $\uparrow \quad \ldots$ Tom Johnson's Strumpet \& M ${ }^{\text {r }}$. Andrew's Jovial.

Rival ... $\quad . . . \quad \mathbf{M}^{\mathrm{r}}$. Andrew's Madam \& ' $\mathrm{T}$. Johnson's Conqueror.

Tanner $\quad . . \quad \mathbf{M}^{\mathrm{r}}$. Herber't's Bridget \& T. Johnson's Conqueror.

Trusty... $\quad .$. A Bitch of $\mathrm{L}^{\mathrm{d}}$. Byron's \& $\mathbf{M}^{\mathrm{r}}$. Skipworth's Trusty.

The above six Couple came with Tom Johnson in 1735.

Cruel ... $\quad$... $\quad \mathrm{S}^{\mathrm{r}}$. Tho. Twisden's Kind.

Darling $\quad$... From $\mathbf{S}^{\mathrm{r}}$. John Miller.

Jenny $\uparrow \quad \ldots$ From Mr. Noel got by Chanter of the confederate hunt. Chanter was full brother to $\mathrm{M}^{\mathrm{r}}$. Herbert's Ranter.

Luther $\quad$.. From $\mathbf{M}^{\mathrm{r}}$. Herbert vide his Pedigree.*

Phillis ... $\quad .$. ) From $\mathbf{M}^{\mathrm{r}}$. Noel got by a son of

Taker $\uparrow \quad \ldots\} \quad M^{\mathrm{r}}$. Thompson's Madcap.

Walcot $\dagger \quad \ldots$ From $\mathbf{M}^{\mathrm{r}}$. Noel vide his Pedigree.

The above three Couple \& a half were given hounds.

* See page 51. 


\section{Records of the Old Charlton Hunt}

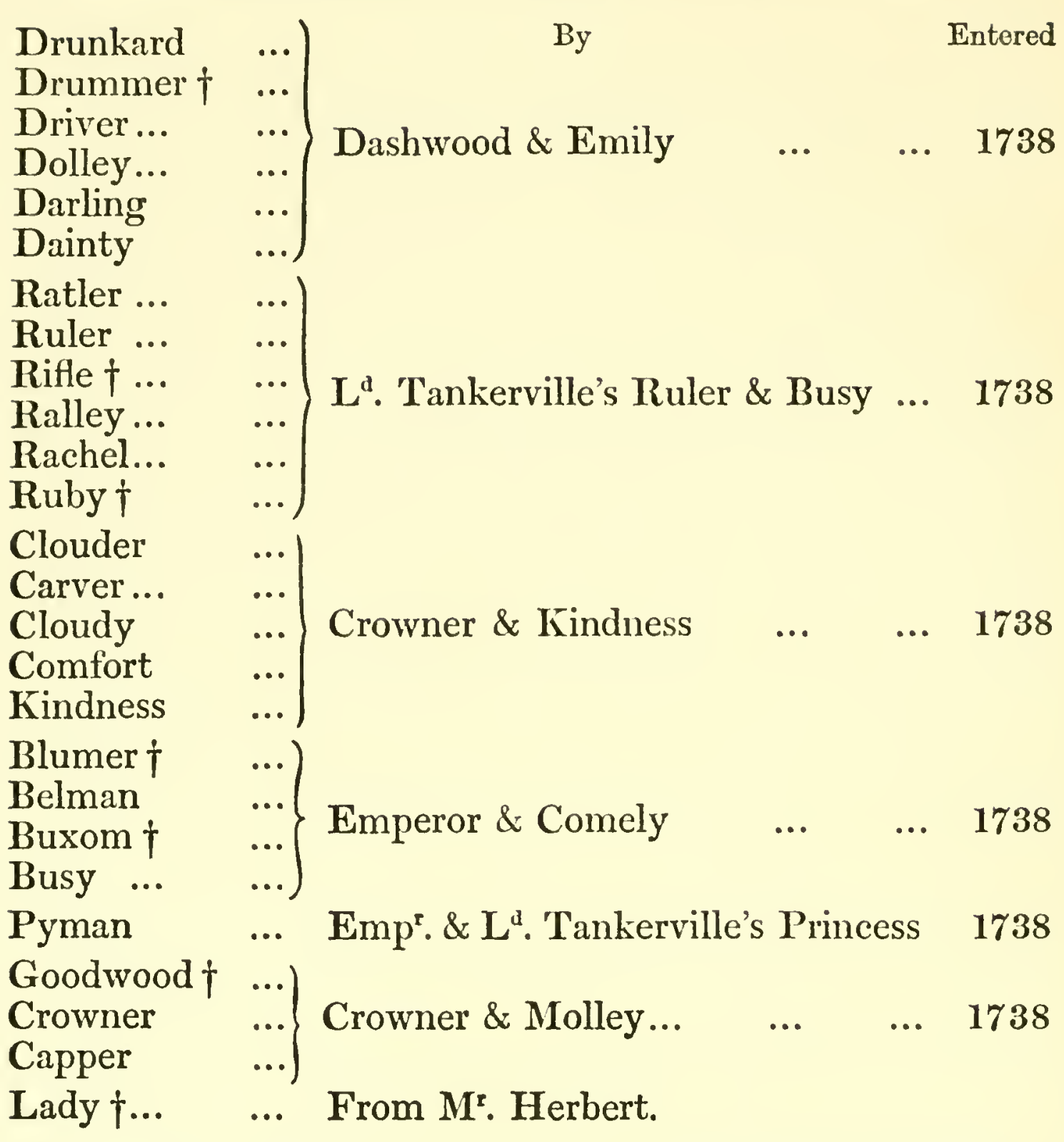

The above thirteen Couple were entered this year 1738 .

In all fifty-three Couple and a half.

Crowner $\dagger \quad$... Belongs to David, \& given him by Mr. Morley.

N.B. Those marked thus, $f$, with a crofs, were at the death of the famous bitch fox, kil'd at South Stoke. Jan. 26, 1738-9. (Page 67.) 


\section{Records of the Old Charlton Hunt}

The Pedigree of Luther sent to the Duke of Richmond by $M^{*}$. Bright of Badsworth, 1733.

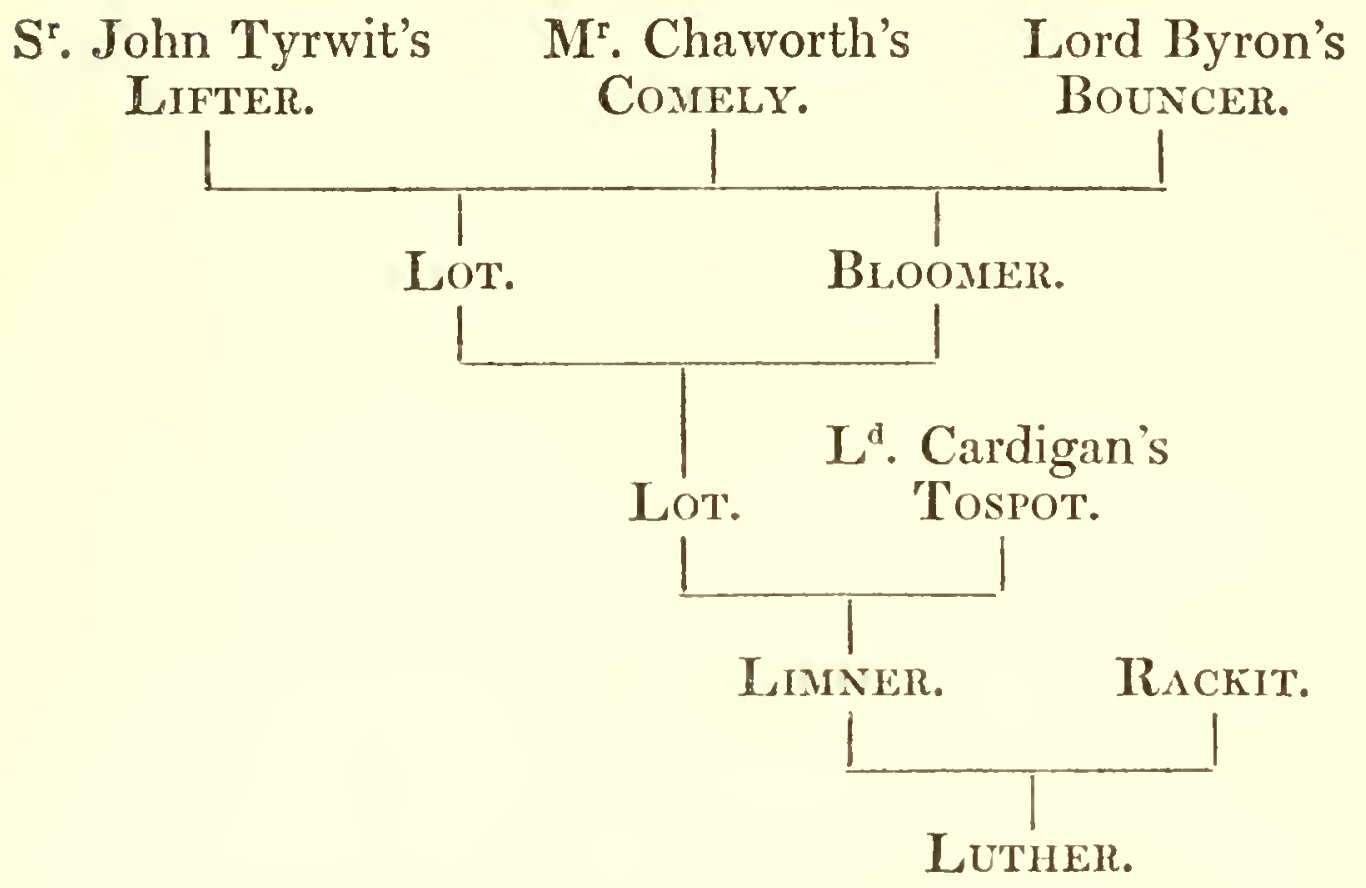

$L^{d}$. Cardigan's

Sussex Gamester.

$\mathbf{M}^{\mathrm{r}}$. Huddleston's $\quad \mathbf{M}^{\mathrm{r}}$. Vernon's

Blameless. BlewCap.

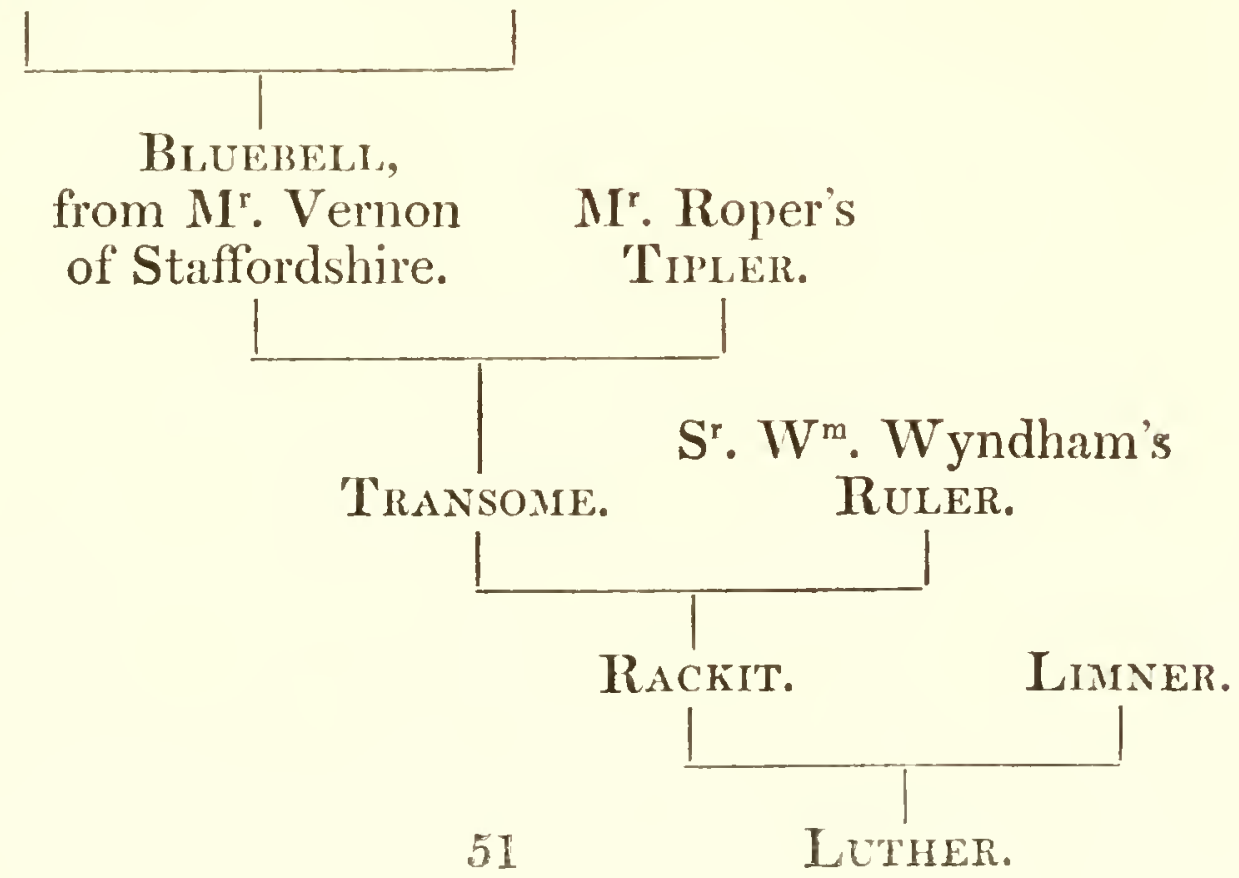




\section{CHAPTER VI}

\section{EXTRACTS FROM THE DUKE'S DIARY (ABOUT 45 DAYS' HUNTING)}

In making these extracts from my ancestor's diary I have endeavoured to select days which struck me as being noteworthy by reason of some quaint expression, or unusual incident, recorded by his pen.

And if my readers should find a sameness throughout the accounts of the 45 days' hunting which I have transcribed from the yellow pages (still rough with the sand with which they were freely sprinkled in those pre-blotting paper days) I crave their indulgence, inasmuch as the "embarras de richesses" with which I found myself engaged made it difficult to decide where to draw the line.

It will be noticed that each entry is headed by a list of the horses that were sent out; and that the Hunt Servants appear in the right-hand column.

Mr. St. Paul was the Duke's stud groom. He was a Frenchman, and came from the Richmond estate of Aubigny, the residence of Louise de Querouaille, Duchess of Portsmouth, and mother of the first Duke of Richmond.

But as for Tom Leaver, Will Macey, Joe Budd and others who appear so constantly in these pages, there is little, if anything, to be gleaned concerning them. 



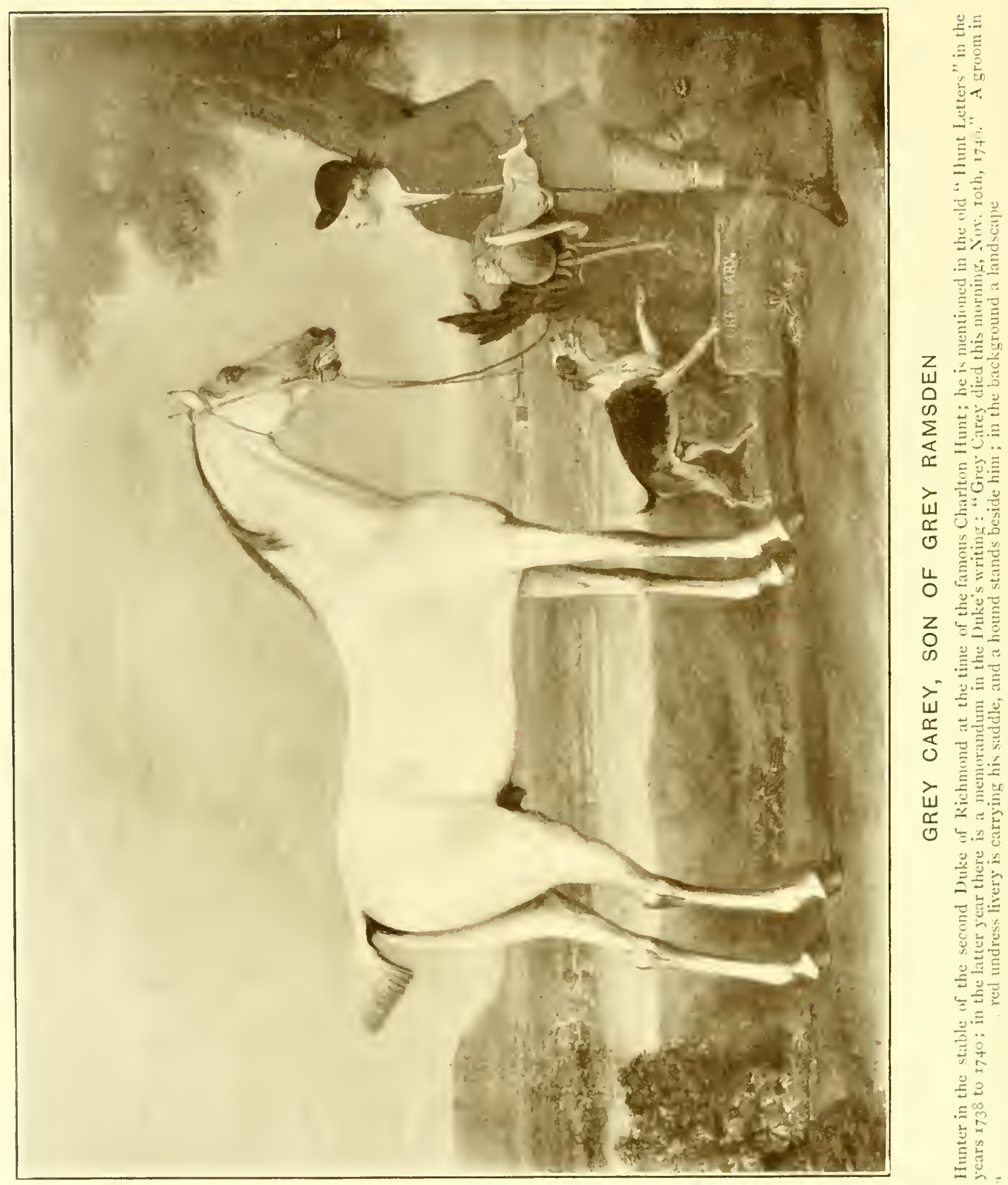




\section{Records of the Old Charlton Hunt}

They were undoubtedly local sportsmen in some way connected with the Establishment of the Hunt.

\begin{tabular}{l|l|l|l}
\multicolumn{2}{r|}{ Horses in my Stable. } & \multicolumn{2}{c}{ Horses in the Huntsmen's } \\
Stable.
\end{tabular}

Tuesday : Nov'. 21, 1737.

\begin{tabular}{llll|lll} 
Gin & $\ldots$ & $\ldots$ & My Self. & Windsor & ... & Tom Johnson.
\end{tabular} Grey Carey Tom Leaver. Frost face... David. $\begin{array}{lllll}\text { Cheat ... } & \text {... } & \text { Joe Budd. } & \text { Walker ... } & \text { Nim. }\end{array}$

Found at the Willum, nine couple ran of with Lord de Lawarr, orer Bow hill to Charlton forrest, East dean wood, Teglees, \& back to Crows hole, the rest went with an other fox to the Haslet, \& because of my Lord Tankervilles hounds made nothing of the scent, so try'd back to the Willum, \& from thence to Phillis Wood, where they found a fresh fox, \& ran several rings in the same wood, Nuncton Parke, \& Lukenor's Cops's, then over Cocking warren to the Marlos, then back to Lewknors Cops's, Sadlers Furz, Muncton Furz, \& to Muncton Parke, where wee took off, it being night, \& all the horses tired. 


\section{Records of the Old Charlton Hunt}

\section{Thursday : Nov' 23.}

\begin{tabular}{lll|lll} 
Looby... & ... My Self. & Madger & ... & Tom Johnson.
\end{tabular}

Slug ... ... Will Macey. Pickadilly... David.

Royal ... ... Tom Leaver. Spot ... ... Nim.

Saucy face ... $\mathbf{M}^{\mathrm{r}}$. $\mathrm{S}^{\mathrm{t}}$. Paul.

Found in the Valdy, where the hounds ran several rings, most excessively hard, for half an hour, then broke cover by Heberdens feilds, over Binderton down, then down by Binderton Farm, up to Crows hole, from thence directly up Bow hill, down to Chilgrove, \& from thence towards the warren, along Chichester road, butt headed back again up Bow hill, over to a Rue between the Willum, \& East Marden, where wee kil'd him, a dog Fox.

\section{Tuesday : Nov ${ }^{\mathrm{r}} \cdot 28$.}

\begin{tabular}{lll|lll} 
Looby & $\ldots$ & My Self. & Badger & .. & Tom Johnson.
\end{tabular} Slug ... ... Will Macey. Pickadilly David. Royal ... ... Tom Leaver. Spot ... $\quad$... $\quad$ Nim. Saucy face... $\mathbf{M}^{\mathrm{r}}$. $\mathbf{S}^{\mathrm{t}}$. Paul.

'Try'd the Valdy butt the hounds did not find, yett a fox stole away from the same cover behind us, \& was seen \& hallood by the Duke of $\mathbf{S}^{\mathrm{t}}$. Albans, Lord De Lawarr \&c; then went \& found in Stoke Cops's, from whence wee ran directly to Adsden, \& there to ground, Nim Ives stay'd \& dug her, a bitch Fox, (butt she was brought home \& given to the hounds on Thursday, her under jaw being broke \& the young hounds wanting blood.) 'Then wee went to the Willum, found imediatly, \& ran several rings in the 


\section{Records of the Old Charlton Hunt}

Innums, Pittlands, Haslet, \& back to the Willum; then back to the Haslet, where I lost them, then they went to Stansted Forrest, \& there it beeing dark, they took off the hounds.

Wednesday : Dec . 6 .

\begin{tabular}{ll|lll} 
Sturdy lump My Self. & Badger
\end{tabular}

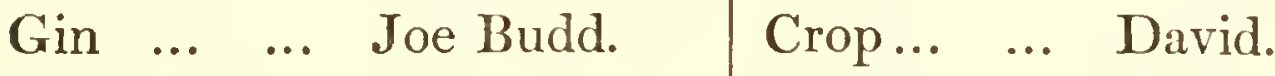

Grey Carey Tom Leaver. Walker ... Nim. Royal ... Tom Dorden.

Found in Lewknors Cops's, run over the Hills above Moncton Parke to 'Treford hanger, \& from thence to the Cops's below Hartin beacon, where the wind was so high, wee could make nothing more of the scent, then in our way home wee found a fresh fox, at the Marlos, who ran directly to the side Hills below Cocking warren, to Treford hanger, \& down to Bepton, from whence he went over to the Com̃ons, \& so to Stedham where they kil'd him, a Dog Fox. N.B. nobody besides the huntsmen were at the death butt Lord James Cavendish.

Munday : Dec ${ }^{\mathrm{r}} \cdot 11^{\text {th }}$.

\begin{tabular}{ll|ll} 
Grey Carey & My Self. & Frost face Tom Johnson.
\end{tabular} Gin ... ... Tom Leaver. Goliah ... David. Fidler ... $\quad . . \quad$ Joe Budd. $\quad$ Spot ... $\quad . . \quad$ Nim.

Found in the upper Teglees, took a turn round the Teglees, over Eastdean Com̃on, through Randals bottom, the upper Teglees again, over The Hill \& Duncton road to Duncton Chalkpit, through Borlavington hanger, up through Hasle Coomb, over the top of farm Hill, through 


\section{Records of the Old Charlton Hunt}

the feilds by twines, up Littleton bottom to Nomans land, through the Binges to Sellers parke, \& went into a Rabbit berry, butt David pul'd her out by the leg, \& lett her run off in view of the hounds that kil'd her about five hundred yards farther in the Binges, an old Bitch Fox.

\section{Munday : Dec ${ }^{\mathrm{r}}$ 18.}

\begin{tabular}{llll|lll} 
Gin & $\ldots$ & $\ldots$ & My Self. & Badger & $\ldots$ & Tom Johnson.
\end{tabular} Grey Carey Tom Leaver. Forrester ... Billy Ives.

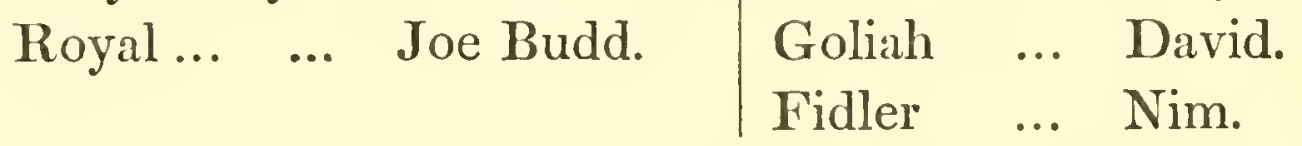

Found in the farther Feilders Furz, ran to the great Feilders Furz, thence through $\mathbf{M}^{\mathrm{r}}$. Ormes ground, up Graffam Hill to Eastdean wood, into Charlton Forrest, back into Eastdean wood, \& there went to ground in a small hole, butt was dug out in a quarter of an hour, \& kil'd, an old Dog Fox.

N.B. I had two new Geldins come down.

\section{8.}

Saturday : Jan. 6.

\begin{tabular}{ll|ll} 
Grey Carey My Self. & Windsor ... & Tom Johnson.
\end{tabular}

Ginn ... ... Tom Leaver. Goliah ... David.

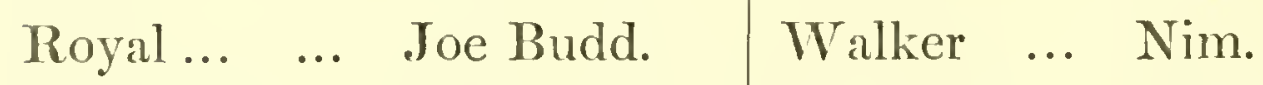

Saucy face ... M Mr. St. Paul. Frost face... Billy Ives.

Found in Trumley Cops, ran to Cuckold-lee Crowshole, up Bow hill by Bradley bushes, almost to the Willum, butt 


\section{Records of the Old Charlton Hunt}

turn'd short back round by $\mathbf{M}^{\mathrm{r}}$. Knights sumer house, down through Westdean Warren, then up to the Hill, between Binderton \& Midlavant, then cross the Lavant up to the Windmill upon Rooks Hill, then down Rooks hill to the Valdy, from thence to Westerton, Sallycops, Hatt hill, down through Strickland's Furz to Charlton Cops. There by a false hallow lost the scent, being then at a dead fault tho'. 'Try'd over the Harrow-ways, to the Valdy, Goodwood Parke, Stricklands Furz, Eastdean Parke, \& Charlton Cops, butt could never recover the scent. It was afterwards thought that the fox went to ground, amongst the Elder trees by Goodwood Parke lodge, which was likely enough because the hounds carry'd no scent beyond the corner of the Parke Pale by the Valdy.

\section{Thursday : Jan. $11^{\text {th }}$.}

\begin{tabular}{lll|lll} 
Slug ... & $\ldots$ & My Self. & Badger & $\ldots$ & Tom Johnson. \\
Looby & $\ldots$ & Tom Leaver. & Pickadilly... & David. \\
Cheat ... & $\ldots$ & Joe Budd. & Spott & $\ldots$ & Nim. \\
Sr. William & Will Macey. & Lord Harcourts \\
& & & Grey Hawley & Billy Ives.
\end{tabular}

Found in Stoke Cops's, run through Stoke Coney Cops to Adsden wood, down by Racton Farm, to Bourne, Bourne Com̃on, Stansted Forrest, so farr the scent was tollerably carry'd on, butt then the coldest scent that ever was round Stansted forrest, the new cutt Peices, Stansted Forrest again, Stansted Parke, over by old Lodge, where the scent began to mend, then to Watergate hanger, where in a 


\section{Records of the Old Charlton Hunt}

hedge Row wee entapis'd * him, \& ran him very hard by Lordington wood to Stansted Parke, Stansted Forrest, the new cutt peices, to Bourn Com̃on again, back to Stansted Forrest, over the Earth at the Syndals to Racton Farm, then by Lordington, up Adsden down, to Adsden Cops, down again to Racton Parke, back again by Lordington Meadows, up to the down, \& into Adsden Cops, \& there they kill'd him, an old Dog Fox.

MundaY : Jan. 15.

\begin{tabular}{ll|ll} 
Grey Carey My Self. & Windsor ... & Tom .Johnson.
\end{tabular} Sturdy Lump Tom Leaver. Goliah ... David. Royal... ... $\quad$ Joe Budd. Walker ... Nim.

$\mathrm{S}^{\mathrm{r}}$. Will ${ }^{\mathrm{m}}$. ... Will Macey. A horse of $\mathrm{S}^{\mathrm{r}}$.

Saucy face ... $\mathbf{M}^{\mathrm{r}}$. S $\mathbf{S}^{\mathrm{t}}$. Paul. Har ${ }^{\mathrm{y}}$. Liddels Billy Ives.

Try'd the Valdy, Broil Cops, Rows, (where the hounds kil'd a martin) Rifles, Ashling woods, \& all Stoke Cops's without finding a fox; butt whilst wee were drawing the last, a Country Fellow Hallood a fox out of a hedge Row by Adsden Farm, wee lay'd on to him, \& ran him directly to Stoke Coney Cops, from thence up Kingly bottom to the top of Bow hill, there turn'd over Stoughton down, all along Adsden down to Adsden Wood, where in the feilds below wee lost him, Peck Williams hounds cornering into us, however wee tryd all round Adsden, \& then down to Stoughton, butt as the night came on, wee took off, \& went home.

* Tapised = "Iurked, lay hid" (Hearne), quoted in Halliwell's Dictionary of Archaisms and Provincilisms, 1887. Cf. French, se tapir, "to crouch." 


\title{
Records of the Old Charlton Hunt
}

\author{
Wednesday : Jan. 17.
}

\begin{tabular}{lll|lll} 
Slug $\ldots$ & $\ldots$ & My Self. & Badger $\ldots$ & Tom Johnson. \\
Looby & $\ldots$ & Tom Leaver. & Pickadilly... & David. \\
Fidler ... & $\ldots$ & Joe Budd. & Frost face... & Nim. \\
S $^{\text {r. William }}$ & $\mathbf{M}^{\text {r }}$. S . Paul. & & &
\end{tabular}

Found a brace of Foxes in Red Cops, David went off with ten comple of hounds to Halnaker with one, \& every body else follow'd the rest after the other fox through Sellers Parke, up to nomans land, in $\mathbf{S}^{\mathrm{t}}$. Mary Wood, down into North Wood, as hard as hounds could run, there they view'd her \& kil'd her, a Bitch fox.

'Then as wee mis'd David \& ten couple of hounds, wee gott as fast as wee could to Halnaker, where wee heard they were gon downwards, \& at Filkens's hole, wee gott into them, \& then with the whole pack wee ran him by Crocker hill, through all the enclosures to Norton, from whence they turn'd short up to Eastham Coñon, leaving Crocker hill, \& Boxgrove of the left hand, \& up to Eastham Comon feilds, where in a hedge Row they kil'd him, a Dog fox.

\section{MundaY : Jan. 22.}

\begin{tabular}{|c|c|c|c|}
\hline $\begin{array}{l}\text { Slug } \ldots \\
\text { Looby } \\
\text { Royal ... } \\
\text { S. Will }\end{array}$ & & $\begin{array}{l}\text { My Self. } \\
\text { Tom Leaver. } \\
\text { Joe Budd. } \\
\text { Mr. St. Paul. }\end{array}$ & $\begin{array}{ll}\text { Badger ... } & \text { 'Tom Johnson. } \\
\text { Pickadilly } & \text { David. } \\
\text { Spott... ... } & \text { Nim. } \\
\text { Ld. De Lawarr's }\end{array}$ \\
\hline & & & Billy \\
\hline
\end{tabular}

Found in East Dean wood, ran the side hills over Heyshot Hanger to the north gate of Charlton Forrest, 


\section{Records of the Old Charlton Hunt}

butt came out imediatly by Lord Montagu's cops's to Hering Dean, into the Forrest again by Foxley Cops, over Cocking highway, through the marlos to Coney Cops, from thence back again through the feilds over Cocking high way, to Cocking course into the Forrest again, through the Forrest \& Eastdean wood, along the side hills, over Woollavington down, Duncton high way, up through Duncton Chalkepitt, down Barlavington hanger, through Burton Parke, old Parke, Red hill, to Coates, leaving Waltham Parke just on the right hand, over Midhurst river, by Fitleworth bridge, where wee cros'd; over the Comon, to Stopham Common, where the fox was found dead, wee beleive kil'd by a grey-hound \& some currs, an old Dog Fox. Wee ran two hours \& thirty eight minutes, \& the hounds behaved extraordinarly well.

\section{WEDNESDAY: Jan ${ }^{\mathrm{ry}} \cdot 24$.}

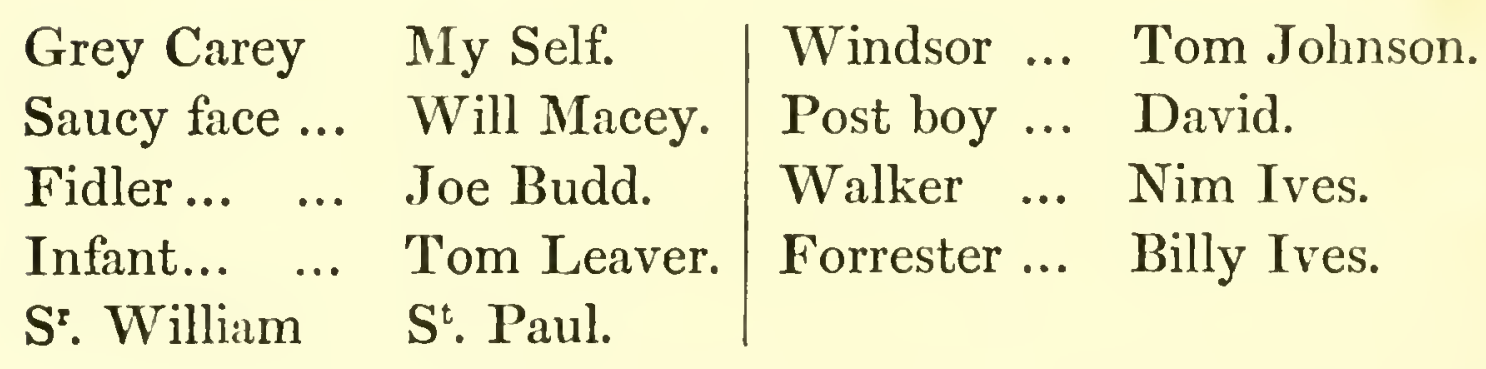

Found in the Winkin, three couple \& a half, with David took it \& went off through Red Cops, Sellers parke, nomans land, Glatten Beacon, to Glatten hanger, the rest took the scent counter, \& could never come up to the three couple \& a half till Glatton hanger, there in a hedge Row, went to ground, wee left him to digg, \& then wee went \& try'd 60 



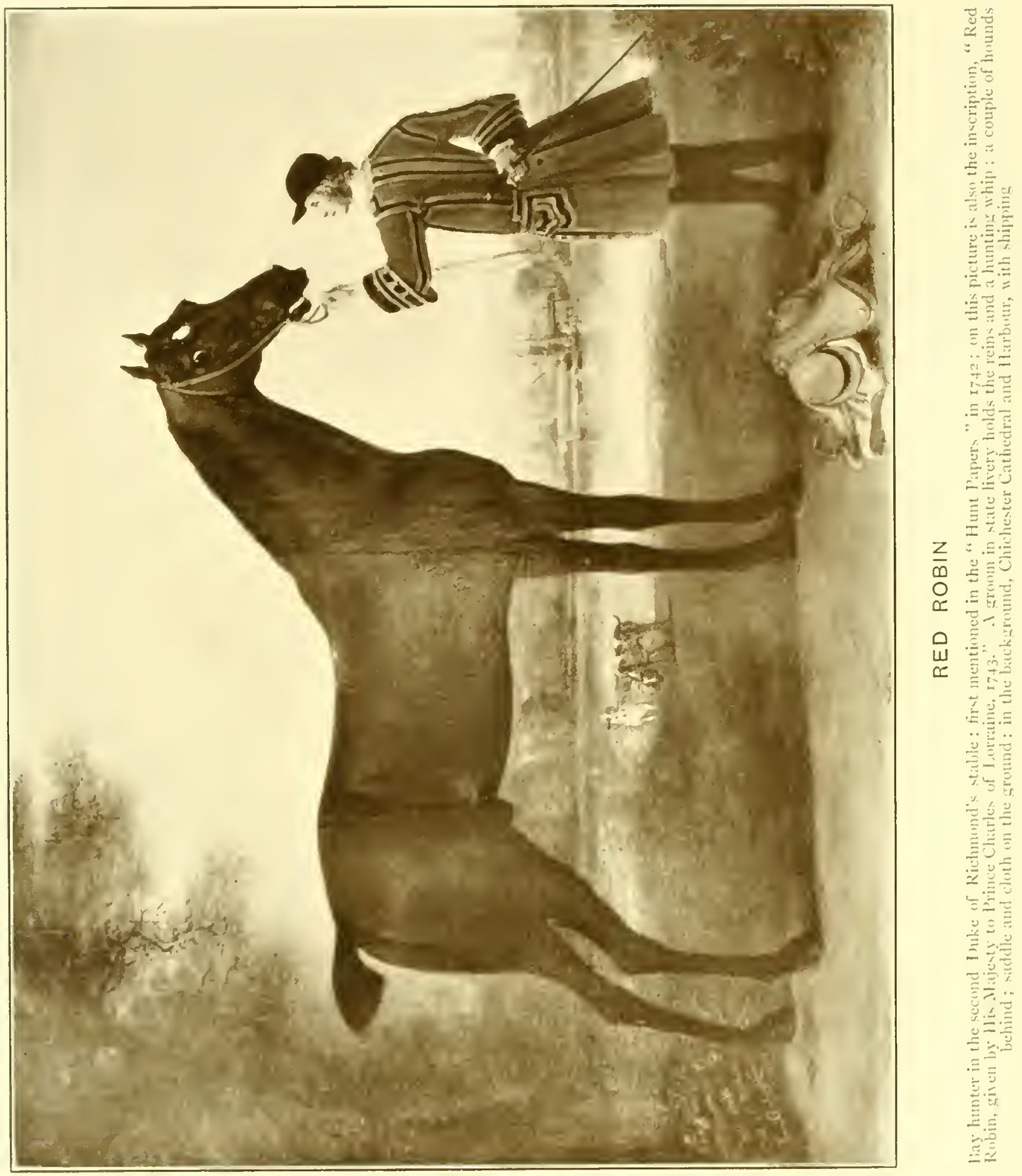




\section{Records of the Old Charlton Hunt}

Dawtrys hooks, \& Kemps Rough peice, where wee had a cold drag, which carry'd us over Slyndon down, Ash Lee, the Conygates, \& so to the Ruel, there wee found, \& had presantly a lease of Foxes on foot, wee ran hard \& chang'd several times, \& then the day altering to very bad weather, $\&$ the scent dying every minute, wee took off \& came home. Nimm dugg out a bitch fox, which wee turn'd out of the Window* at Fox-hall; he also dug two badgers, \& kil'd them both.

\section{THE GRAND CHASE}

FrYdaY : Jan ${ }^{\text {. }} 26$.

\begin{tabular}{lll|ll} 
Slug & $\ldots$ & $\ldots$ & My Self. & $\mathbf{S}^{\mathrm{r}}$. Will \\
\end{tabular}

Looby... ... Joe Budd. Badger ... Tom Johnson.

Sturdy lump 'Tom Leaver. Pickadilly... David.

then at Goodwood I took $\quad$ Walker ... Nim.

Saucy Face My Self. $\quad$ Frost face Billy Ives.

Here is the account of the greatest Chase that ever was :-

A Full \&. Impartial Account of the late remarkable Proceedings at Charlion.

It has long been a matter of Controversy in the Hunting World, to what particular Country or Sett of Men, the superiority of Power belonged. Prejudice, and Partiality

* Let us hope it was the ground floor.

61 


\section{Records of the Old Charlton Hunt}

have had the greatest share in their Disputes, and every Society their proper Champions to assert the Preeminence, and bring home the 'Trophies to their own Country.-Even Richmond Park has its Dimmock. But on Friday, the 26th of January, 173 $\frac{8}{9}$, there was a decisive Engagement on the plains of Sussex, which after ten hours struggle has settled all future debates, and given the Brush to the Gentlemen of Charlton.

At a quarter before eight in the morning the Fox was found in Eastdean wood, and ran an hour in that Cover, then into the forrest, up to Puntice Coppice, thro' Herring Dean to the Marlowes up to Coney Coppice, back thro' the Marlowes to the Forrest west gate, over the Feilds to Nightingale bottom, to Cobdens at Draught, up his Pine-pitt hanger, (there His Grace of St. Albans gott a fall) thro' my Lady Lewkner's buttocks, and mist the Earth, thro' West dean forrest to the corner of Collar down (where Ld. Harcourt blew his first horse, crost the Hacking place down the length of Coney Coppice, thro' the Marlow's to Herring Dean into the Forrest, and Puntice Coppice, East Dean Wood, the lower Teagles, cross by Cocking course, down between Graffim and Woolavington, thro' Mr. Orm's park and paddock, over the lieaths to Feilder's Furses, to the Hurlands, Selham, Amersham, thro' Totham Furses, over 'Totham heath almost to Cowdrey park, there turn'd to the Lime-Kihn at the end of Cocking causeway, thro' Cocking Park and furses, there crossed the road and up the Hills between Bepton and Cocking. (Here the Unfortunate Lord Harcourt's second horse felt the Effect of long Legs and a sudden steep, the best 


\section{Records of the Old Charlton Hunt}

thing belonging to him was his saddle which my Lord had secured, but by bleeding and Geneva (contrary to the Act of Parliament) he recorered, and with some difficulty was got home, here Mr. Fouqueir's Humanity claims your regard, who kindly sympathised with my Lord in his Misfortunes, and had not power to go beyond him.) At the bottom of Cocking warren the Hounds turned to the left, across the road by the Barn, near Herring-dean, then took the side hills to the north gate of the Forrest, (here $\mathrm{B}^{\mathrm{r}}$. Hawley * thought it prudent to change his horse, for a True-blew that staid upon the Hills, B. Ires likewise took a horse of Sr. Harry Liddels) went quite thro' the Forrest and run the Foil, thro' Nightingale bottom, to Cobdens at Draught, up his Pine-pitt hanger, to my Lady Lewkner's buttocks, thro' every Meuse she went in the morning, went thro' the Warren above Westdean, where we dropt Sr. H. Liddel, down to Binderton Farm, (here Ld. Harry sunk) up to Binderton down, thro' Hayes bushes, Beechley bushes, to the Voldi, through Goodwood Park, (here the Duke of Richmond chose to send three lame Horses back to Charlton, and took Saucy-Face and Sr. Wm. that were very luckily at Goodwood) from thence at a distance Ld. Harry was seen driving his Horse before him to Charlton. The hounds went out at the upper end of the Park up to Stretington road, by Sally Coppice (where his Grace of Richmond got a somerset) through Halnaker Park over Halnaker hill to Sebbige farm, (there the Master of the Stag-hounds, Cornet Honeywood, Tom Johnson, and

* A eelebrated soldier of the day, he earned a reputation for relentless severity towards enemies of the Crown, notably in the ' 45 rebellion. 


\section{Records of the Old Charlton Hunt}

Nim Ives were thoroughly satisfied) up long-down, thro' Eartham common Feild to Kemp's high wood. (Here B. Ives tired his second Horse, and took Sr. Wm. by which the Duke of St. Albans had no great coat, so returned to Charlton.) From Kemps high wood the hounds broke away thro' the Gumworth Warren, Kemps ruff-piece, over Slindon down, to Madhurst Parsonage where Billy came in, with them over Poor down, up to Madhurst down, Houghton Forrest where His Grace of Richmond, B $\mathbf{B}^{\mathrm{r}}$. Hawley, and Mr. Pauncefort came in, the latter to little purpose, for beyond the Ruel hill, neither Mr. Pauncefort, or his Horse Tinker cared to go, so wisely returned to his Impatient, Hungry Friends. $U_{p}$ the Ruel Hill, left Sherwood on the right hand, crost Offam hill to Southwood, from thence to South Stoke to the Wall of Arundell river, where the Glorious Twenty Three Hounds putt an end to the Campaign, and killed The Old Bitch Fox, 10 mints. before six. Billy Ires, His Grace of Richmond, and $B^{r}$. Hawley were the only Persons at the Death, to the Immortal Honour of 17 stone; and threescore, and at least as many Campaigns. 


\section{Records of the Old Charlton Hunt}

The Measure of the Fox Chase that was run Friday Jan. 26, 1738-9.

Jan. 31 begun From the East Side of East Deane wood to the lower Tegleys, Buckleys, Mr. Orme's Park, Northwood Farm, Selham Furzes, Fielders Hop Garden, by Selham Barn, thrô the inclosed fields belonging to Selham and Ambersham, to Ambersham Furzes, over the Brook by Dunford Farm, to Aukers Furze, cross Cocking Causey by the lime kiln, to paddocks wood, Henly Coppice, halfpeny wood, then cross the london road, up by Herring-Dean Barn, to Suncoombe, over Cocking Course to Puntys Coppice, thrô the Forrest by the Stone Table, to Nightingale bottom, thrô the Hangers to Draught, up pine-pit Coppice, to Downley house, Whistling-alley Coppice, Heydon Barn, Cross the South end of West-Deane Warren, by Binderton Farm, up the Downs by Hayes Bushes, thro Bickleys Bushes, cross the inclosures into Valdy, thrô Goodwood Park and out at the upper Gate, the Miles. Furl. Rod. $\begin{array}{llllllll}\text { whole in length } & \ldots & \ldots & \ldots & \ldots & 24 & 6 & 31\end{array}$

Feb. 1 begun From Goodwood upper Gate, cross above Saily Coppice to Lady Derbys Rookwood, over by Halnaker 


\section{Records of the Old Charlton Hunt}

windmill to Sebidge Farm, over long Down, Eartham Common field, quite thrô Mr. Kemps high wood to the raild peice, thrô the inclosures to Slyndon inDown, to Madhurst parsonage, over Madhurst down to Fair mile, thrô the inclosures to Madhurst Church and so to Houghton Forrest, cross the road by the way post, over Houghton Down, to South wood, thrô the inclosed fields of South Stoke down to the Brooks, where the wheel could not follow him.

Miles. Furl. Rod.

$\begin{array}{llllll}\text { the whole in length } & \ldots & \ldots & 11 & 3 & 24\end{array}$

Allowd for the Brooks, by Mr.

$\begin{array}{lllllll}\text { Gideons's opinion ... } & \ldots & \ldots & 1 & 0 & 0\end{array}$

Allowd by Billy Ives for the 3 hours running in Cover ... $\quad \ldots \quad \ldots$

\begin{tabular}{rrr}
20 & 0 & 0 \\
\hline 57 & 2 & 15
\end{tabular}




\section{Records of the Old Charlton Hunt}

The Glorious Twenty Turee Hounds that were at the Death of the Bitcr Fox below South Stoke, after having run her from a quarter before Eight in the Morning, till ten minutes before Six in the Evening, on Friday the 26th of January, 1738-9.

\begin{tabular}{l|c} 
Old Hounds. & Young Hounds. \\
Pompey. & Buxom. \\
Doxy. & Ruby. \\
Taker. & Rifle. \\
Jenny. & Bloomer. \\
Peggy. & Goodwood. \\
Dido. & Lady. \\
Musick. & Crowner. \\
Ringwood. & Drummer. \\
Lawyer. & \\
Cruel. & \\
Veny. & \\
Edmund. & \\
Walcut. & \\
Cryer. & \\
Traveller. &
\end{tabular}




\section{Records of the Old Charlton Hunt}

Tuesday : Feb. $13^{\text {th }}$.

S. William My Self.

Grey Carey Will Macey.

Badger ... 'Tom Johnson.

Cheat ... Joe Budd.

Forrester ... Billy Ives.

Infant $\quad \ldots \quad \mathbf{M}^{\mathrm{r}}$. S $\mathrm{S}^{\mathrm{t}}$. Paul.

Goliah ... David.

Sturdy lump Ld. Molyneux's

huntsman.

Found in the Valdy, went out for the sand pitts, butt turn'd Short back to the Valdy, through Goodwood Parke, over hasteds down, through the Winkin, North-hanger, crofs the East-dean road, up the 'Teglees hill, through both upper \& Lower Teglees to East Dean wood, \& Charlton Forrest, there Ives chang'd, \& after some turns to Herring Dean, out by the barn, all along the Downs, over Cocking Course, Hessiod down, Woollavington down, \& up Duncton hill to the Chalke-pit; down Barlavington hill, by Duncton Street to the Comon by Burton Parke, there were at a long fault, \& Nim with ten couple of hounds had gon down before to Woollavington Parke, \& was also at a fault, then the fox was hallow'd up the hill, \& both Parcels comeing up, carry'd the scent into East-dean wood, from thence to the lower 'Teglees, where she went to ground, \& a 'Terryer kill'd her, a bitch Fox. 



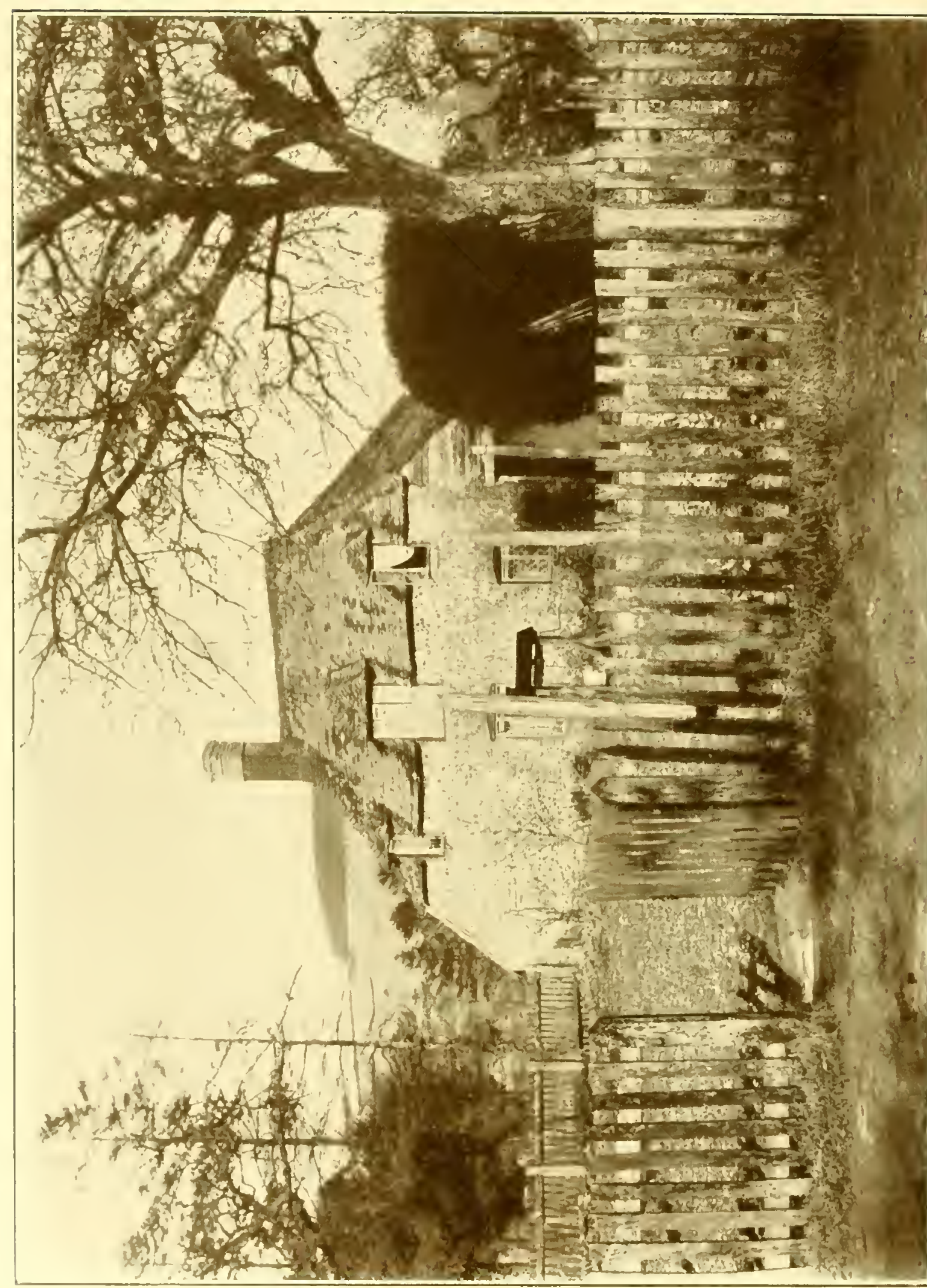

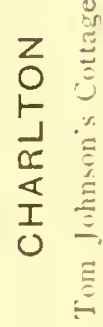




\section{Records of the Old Charlton Hunt}

'Thursday : Feb. 15.

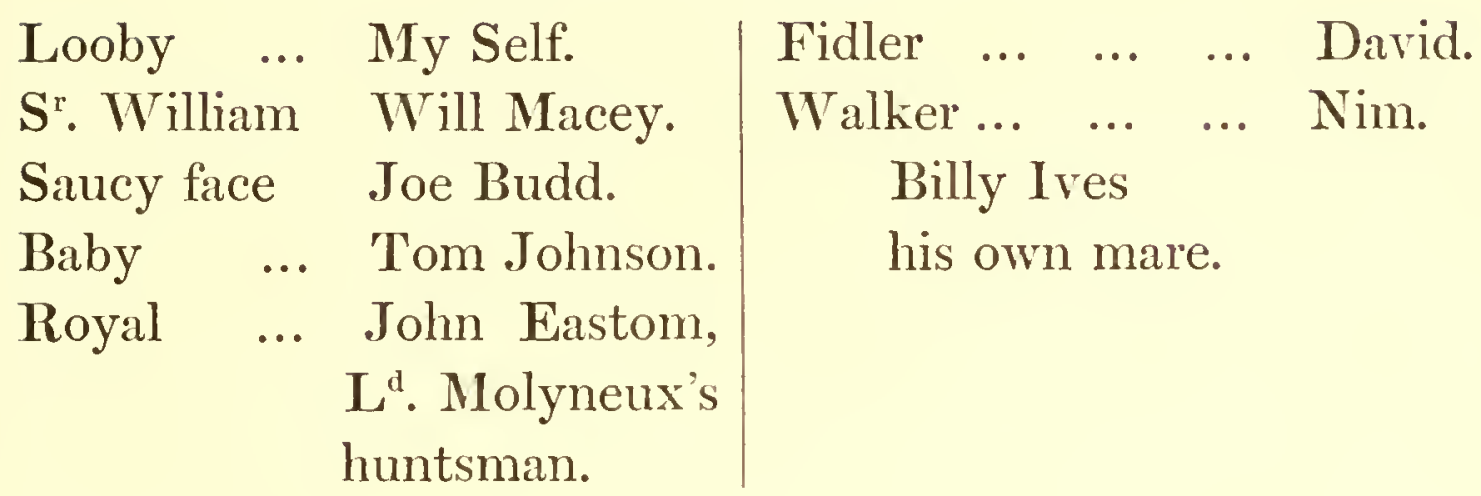

Found in the Valdy, ran through Goodwood Parke to Strickland's Furz, over the Harrow ways to East dean Parke, from thence to Charlton Cops, back again to East dean Parke, the above holts, north-hanger, Red Cops, the Winkin, East dean Parke again, Charlton Cops, back to East dean Parke, above holts, north hanger, \& Red Cops again, so farr a very cold scent, butt from thence the hounds ran as hard as hounds could run to Halnaker Parke, the Red-bins, down between Boxgrore Street \& Filkens's hole, by Crocker hill, the back of Norton, down to Aldenbourn, \& between that \& Lidsey, they kill'd her, a Bitch Fox. 


\section{Records of the Old Charlton Hunt}

\section{LIS'T OF FINDS AND KILLS, SEASON 1738-9.}

1738.

Thursday, Novr. 2. Found in the Valdy, butt did not kill.

Saturday, " 4. Found in Farm Wood, dug \& kill'd in North Coomb ... ... ... ... a Bitch.

Tuesday, " 7. Found in the Valdy, butt did not kill.

Wednesday, , 8. Found in Phillis Wood, kill'd in the Marlows $\quad \ldots \quad \ldots \quad \ldots \quad \ldots \quad$ a Bitch.

Munday, " 13. Found in Rou Cops, butt did not kill.

Wednesday, " 15. Found in Dawtry's hooks, kill'd in Charlton Forest $\quad$.. $\quad \ldots \quad$... a Bitch.

Fryday, , 17. Found in the Ruel, butt did not kill.

Munday, "20. Found in Broil Cops, butt did not kill.

Tuesday, " 21. Found in the Willum, butt did not kill.

Thursday, " 23. Found in the Valdy, kill'd by Majr. Battines... $\quad \ldots \quad \quad \ldots \quad \quad \ldots \quad \ldots \quad$ a Dog.

Saturday, " 25. Found in the Ruel, butt did not kill.

Tuesday, " 28. Found in the Valdy, kill'd at Adeden ... a Bitch.

Fryday, Decr. 1. Found in the Ruel, butt did not kill.

Munday, " 4. Found in the Valdy, kill'd in the Binges a Bitel.

Wednesday, " 6. Found in Lewknor's Cops, kill'd at Stedham $\quad \ldots \quad \ldots \quad \quad \ldots \quad$... $\quad$ a Dog.

Fryday, " 8. Found in Lewknors Cops, butt did not kill.

Munday, " 11. Found in the Teglees, kill'd in the Binges a Bitch.

Tuesday, " 12. Found at Burton, butt did not kill.

Fryday, " 15. Found in Charlton Cops, kill'd upon Harteds Down ... ... ... ... a Bitch.

Munday, " 1S. Found in Feilder's Furz, kill'd in East Dean Wood ... ... ... ... a Dog.

Tuesday, "26. Found in Stoke Cops, kill'd at Stansted a Dog.

Fryday, " 29. Found at the Broil, butt did not kill.

$173 \frac{8}{3}$.

Munday, Jan' ${ }^{r y}$. Found in the Rous, kill'd in Broil Cops a Bitch. 


\section{Records of the Old Charlton Hunt}

Fryday, Jan'ry 5. Found in East Dean Wood, kill'd in Randall bottom $\quad \ldots \quad \ldots \quad \ldots$ a Bitch.

Saturday, " 6. Found in Trumley, butt did not kill.

Munday, " 8. Found in the Teglees, kill'd in the Teglees a Dog.

Wednesday, " 10. Found in Trumley, kill'd in East Dean Parke ... $\quad . . \quad \quad \ldots \quad \quad \ldots \quad$... a Bitch.

Thursday, " 11. Found in Stoke Cops, kill'd in Adeden Wood ... $\quad \ldots \quad$.. $\quad \ldots \quad$... $\quad$ a Dog.

Munday, „ 15. Found by Adeden, butt did not kill.

Wednesday, " 17. Found a brace in Red Cops, kill'd one in Kemp's high wood, and t'other in Eartham Coñon feilds $\quad$... $\quad . .$. a Bitch. a Dog.

Fryday, „ 19. Found in Hebedon Cops, kill'd in Arundel

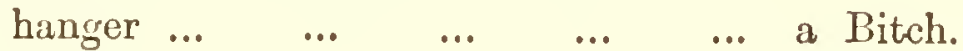
Found in Arundel Parke, kill'd in W. Burton Hanger $\quad \ldots \quad$... $\quad \ldots$ a Dog.

Munday, " 22. Found in East Dean Wood, kill'd upon Hopham Coñon $\quad \ldots \quad$... $\quad$.. $\quad$ a Dog.

Wednesday, "24. Found in the Winkin, butt did not kill.

Fryday, , 26. Found in East Dean Wood, kill'd below South Stoke. The Great Chase ... ... a Bitch.

Munday, ", 29. Found in Dawtrys hooks, kill'd by Drought $\quad \ldots \quad \ldots \quad \ldots \quad \ldots \quad$ a Dog.

Thursday, Feb. 8. Found in Puntys Cops, butt dug out a Bitch at Hundon.

Saturday, " 10. Found in East Dean Wood, kill'd in Charlton Forrest $\quad \ldots \quad$... $\quad \ldots$ a Dog.

Munday, " 12. Found in Dawtrys hooks, kill'd in the Rooks ... $\quad . . \quad \ldots \quad$... $\quad \ldots$ a Bitch.

Tuesday, " 13. Found in the Valdy, kill'd in the Teglees a Bitch.

Thursday, " 15. Found in the Vady, kill'd at Alden bourn a Bitch.

Saturday, " 17. Found in the Rooks, butt did not kill.

Tuesday, " 20. Found in East Dean Wood, butt did not kill, however dug out an old Dog fox. 


\section{Records of the Old Charlton Hunt}

Thursday, Feb. 22. Found in Charlton Forrest, butt did not kill.

Saturday, " 24. Found in the Rows, butt did not kill.

Munday, „, 26. Found in Red Cops, butt did not kill.

$$
\begin{aligned}
& \text { Kill'd-Dog Foxes } \quad \ldots \quad \ldots \quad \ldots \quad 11 \\
& \text { Bitch Foxes ... ... ... } 16 \\
& \text { In all ... } \quad \ldots \quad \ldots \quad \ldots \quad 27 \text { foxes. } \\
& \text { Mifs'd killing } \quad \ldots \quad \ldots \quad \ldots \quad \ldots \quad 20 \text { times. } \\
& \text { butt as foul foxes were kill'd in twice } \\
& \text { going out, wee, hunted in all ... } 45 \text { times. } \\
& \text { remain } \quad . . \quad \ldots \quad 46
\end{aligned}
$$

\section{Munday $: \mathrm{Nov}^{\mathrm{r}} \cdot 5^{\text {th }}$.}

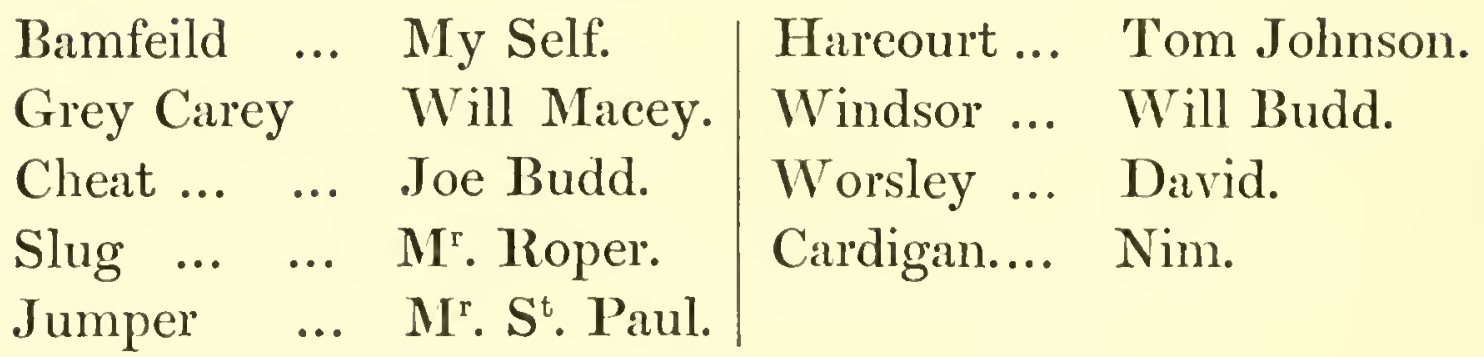

Found in the Valdy, run over Goodwood warren, Stricklands Furz's, into East-dean parke, through both Winkins, over Lady Derby's sheep down, \& at the rails came to a fault, so farr the hounds ran very hard, butt after 


\section{Records of the Old Charlton Hunt}

several casts from thence, the fox was recovered by Halnaker street, \& from thence they carry'd a cold scent over Boxgrove Com̃on, Eastham Com̃on, Eastergate Com̃on, $\&$ so into Glyndon Cops, from thence over Glyndon Comon into Walburton Cops, there they had an entapis, butt to no purpose, for the wind being excefsively cold at North East, the hounds could not carry on the least scent, so wee took off \& came home.

\section{Saturday $:$ Dec ${ }^{\text {r }} 8^{\text {th }}$.}

\begin{tabular}{llll|lll} 
Slug & $\ldots$ & $\ldots$ & My Self. & Jersey & $\ldots$ & Tom Johnson.
\end{tabular}

Grey Carey... Will Macey. Post boy ... David.

Bamfeild ... Joe Budd. Worsley ... Nim.

Cheat ... $\quad . . . \quad M^{r}$. Roper. $\quad$ Frosty face Jack Row.

Found in the Redbins, ran through Lady Derby's grounds, her Rookwood, over her sheep-down to Redcops, North hanger the bove-holts, Eastdean Parke, then back over Eastdean Harroways, through $\mathbf{M}^{\mathrm{r}}$. Orms's, \& Lady Derbys winkin, over Lady Derby's sheep down again, into Halnaker Parke, through the grove, down the Hanger in the parke, through the Rookwood again, into the Chalk pitt, two feilds beyond the Rookwood, there went to ground, dug her \& kill'd, a young Bitch fox. 


\title{
Records of the Old Charlton Hunt
}

\author{
Tuesnay : Dec ${ }^{\mathrm{r}} \cdot 11^{\text {th }}$.
}

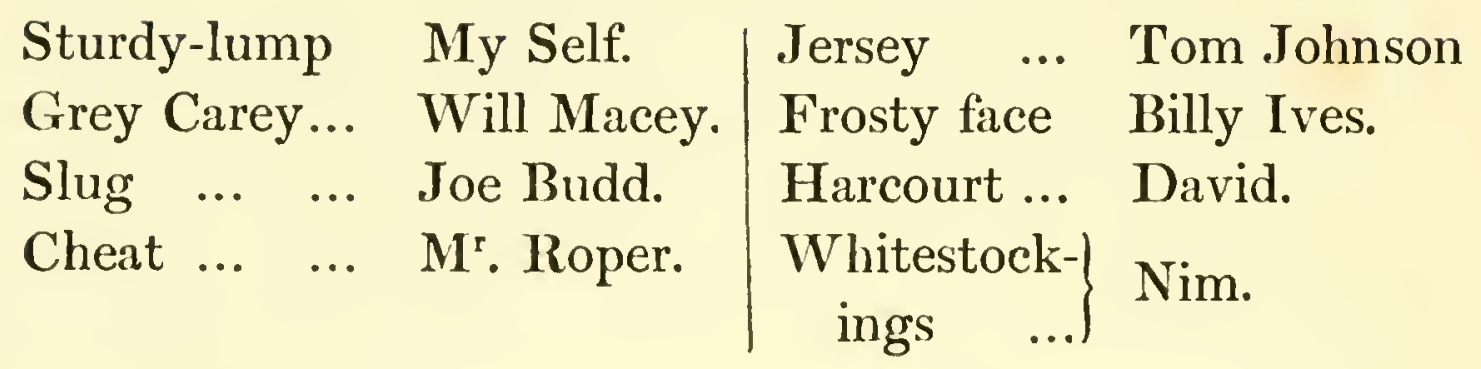

Found a brace of Foxes in the William, Tom Johnson with one \& two brace \& a half of hounds, went directly over Bowhill to Jermyn-leath, the rest of the pack went off to the Haslets, to Watergate, then turn'd back to the Innums, down by the Pittlands, up to Long hill, the whole length of that, crofs the Winchester Road, through North Marden feilds, there by Jermyn leath, came into Tom Johnson; through Jermyn leath, to Phillis wood, back by Phillis farm \& the Eslands to North Marden, from thence over the Downs \& Lord Tankervilles warren, into Upparke; there by the kitchen garden wall, turn'd back over Harting hill, then up to Harting-beacon, \& to Jermyn leath again, Phillis wood \& Muncton parke, back through Phillis wood again to Jermyn leath, \& there came to a dead fault, butt 'Tom Johnson upon a cast to the Winden, either hitt it off again, or found a fresh fox in the Winden, \& from thence they ran down almost to Chilgrove, round the enclosures there, \& back again to Phillis wood, Muncton Parke, through the Winden to Lukenors Cops's; there they had so many scents on foot that they were forced to take off, tho' not without very great difficulty, for the hounds were dispers'd all over the whole country; 'Tom Johnson was forc'd to go to Charlton forrest where some of them had carry'd a fresh 


\section{Records of the Old Charlton Hunt}

fox from Lukenors cops; \& Nim Ives went back as farr as Phillis wood to take off an other parcel that had also carry'd a fresh fox thither, \& David Briggs with difficulty gott off the rest in Lukenors Cops's.

WeDNesDaY: Dec ${ }^{\mathrm{r}} \cdot 19^{\text {th }}$.

N.B. I was still in London. $\mid$ Jersey $\quad$.. $\quad$ Tom Johnson. Cheat $\ldots . \quad \ldots \quad \mathbf{M}^{\mathrm{r}}$. Roper.

Harcourt ... David.

Whitestock-1
ings Nim.

Forrester ... Billy Ives.

Took a drag above Waltham, at the beginning of Randall's bottom, which lasted half an hour to the further side of East dean Wood, There he went off, round the outside of the forrest, through Herring-dean, was headed at Cocking road; came back through the feilds to Nightingall bottom; from thence to Broad-ham, through the bottom of Charlton Forrest, \& East-dean Wood, took a large ring in the lower 'Teglees, \& came back along the side hills, the out side of Charlton forrest, through Herring-Dean, acrofs Cocking-high way, up the Marlows, as farr as Collar-down, there abouts the hounds parted, about sixteen couple came back almost to Coney Cop's, \& thereabouts they changed. The Fresh fox flew at once for Cocking Chalk-Pitt; turn'd there for Sadler's Fuzz's, butt went by them \& cros'd, for the side hills, \& for the Winden, kept up by the outside, \& by Muncton Parke, through the feilds by Jermyn-leath, cros'd there other feilds at the bottom for Treeford earth, 


\section{Records of the Old Charlton Hunt}

from thence kept the steeps, up the trundle to Hartinbeacon, there the company saw him, the hounds did not view him, over Harting Windmill Hill into Upparke, by the kitchen garden \& Dog-kennell, close by the house, there there was a short cheque, then cros'd him again close by the front of the house, from thence to Lady-holt-Parke gate, turn'd there over the Hill, for Harting down, \& then for Ditching Parke; by the wood side they had a cheque, \& whilst they were trying, a man told them he saw him go into the main earth, which proved true, so they came home.

1740.

Munday: March $17^{\text {th }}$.

Gin ... ... My Self.

Grey Carey\{ $\begin{aligned} & \text { Young } \\ & \text { Johnson. }\end{aligned}$

Sr. William Will Macey.

Badger ... Tom Johnson.

Pickadilly David.

Spott ... Nim.

Slug $\quad .$. Will Green.

Bamfeild... Jemy Gardiner.

Royal ... Joe Budd.

Found in the Marlo's, ran up to the hacking place, through Coney Cops, then back again through the Marlo's, crofs Cocking high way, to the feild by Herring Dean, then I saw the fox \& hollow'd him back again to Cocking Warren, into Coney Cops, to the Soveraign, Venus Cops, through Lukenor's cops, Muncton Parke, Winden, Phillis Wood, Germin leath, to Upmarden, along Upmarden down to Harting beecon, thence to the earth at 'Treford, 



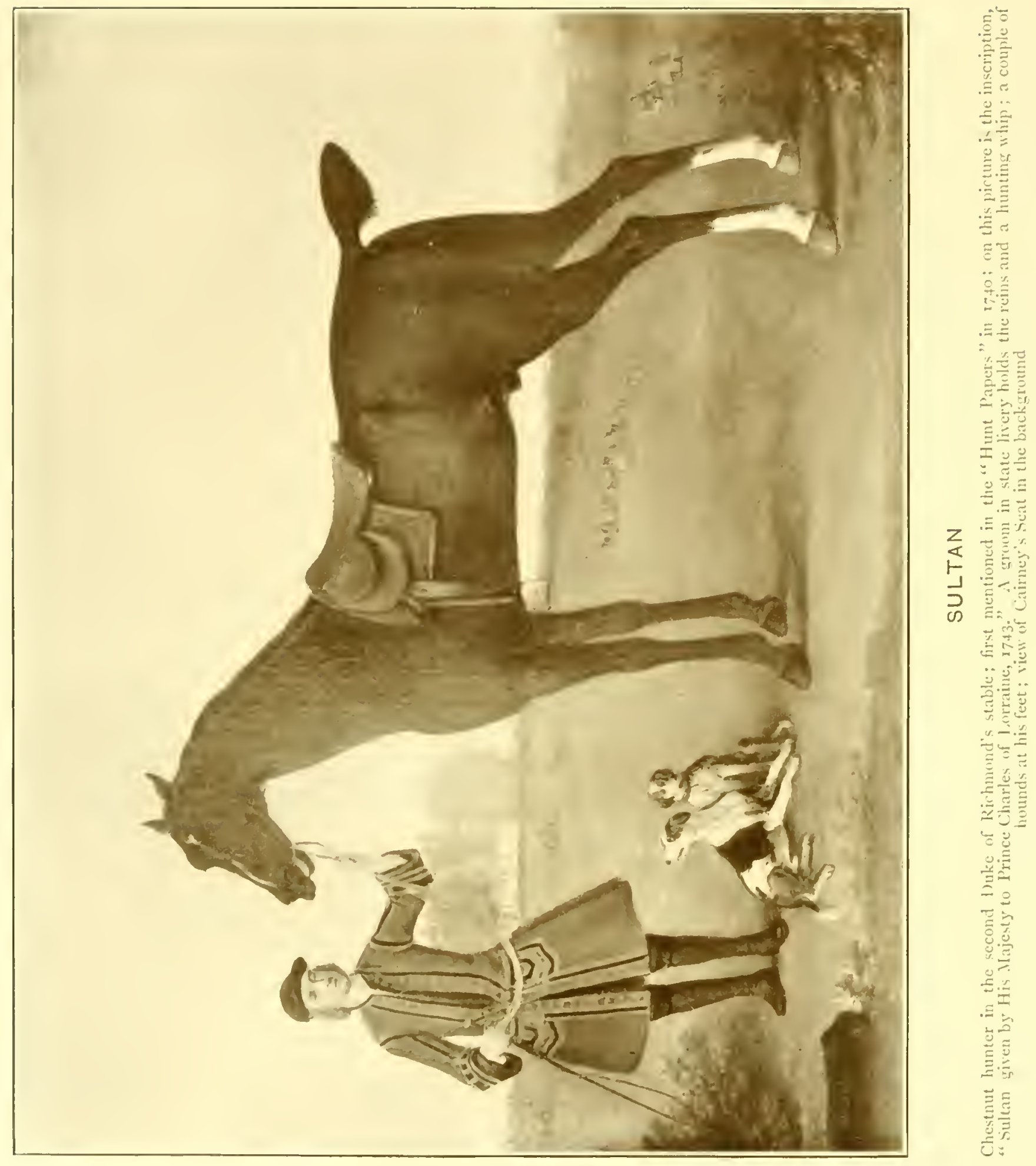




\section{Records of the Old Charlton Hunt}

went to ground \& in the mean while a fresh fox came up the Hill, through Germin leath, \& a long the hills, leaveing all the covers on the right hand till he came to Lewknors Cops's, there wee had a dead fault butt recover'd it again in Muncton Parke, for he was headed back by Workmen, then wee carry'd the scent as farr as Germin leath, butt could make it out no farther, so Tom Johnson Cast to Treford earth, \& round to Lewknors Cops's, \& there found Peggy who had run him back by herself, then wee had several rings upon a cold scent that at last wee could make nothing of it, so came home, butt Walcutt \& a 'Tarryer, ran him by themselves to the Warren house at Cocking, where they say he lep't up a top of the house, \& came down the chimney, \& they call'd in the two dogs \& catch'd her, \& brough her here, a bitch fox with whelp. David went off with 13 couple of hounds, \& had a fine run along the side hills, to Twines, butt there in the dry fallows could make nothing of it.

WEDNESDAY : Nov'. 5.

\begin{tabular}{lll|lll} 
Sultan ... & $\ldots$ & My Self. & Jersey & ... & Tom Johnson.
\end{tabular}

Sturdy lump Johnson. Worsley ... $\quad$ David.

Slug $\quad . . . \quad \ldots \quad$ Joe Budd. $\quad$ was staked that day.

Sr. William... Will Macey. Forrester ... Jack Row.

Beat Dawtreys hooks, Kemps rough peice, all the country by Burton, East dean wood \& Charlton Forrest, without Finding. The first Blanc day, I ever saw in Sussex.*

* Alas, there bave been many since! 


\section{Records of the Old Charlton Hunt}

$$
\text { Munday : Nov }{ }^{\mathrm{r}} \cdot 10^{\text {th }} \text {. }
$$

Sultan ... My Self.

Looby $\quad \ldots \quad W^{\mathrm{m}}$. Macey.

Bamfeild ... Jock Johnson.

Royal ... Joe Budd.
Windsor ... Tom Johnson.

Walker ... David.

Forrester ... Jack Row.

Found in the Valdy, ran through Goodwood Parke, Coldings Cops, the Redbins, through Halnaker feilds, the Rookwood, by the corner of Halnaker pond, to Lady Derbys Winkin, Red Cops, just over the hedge into Sellers Parke, back again through the north hanger, to East Dean Parke, \& Charlton Cops, back the same way through East Dean Parke North hanger, \& the Winkin to Halnaker feilds, \& Redbins, through Coldens Cops, to the Valdy, \& there ran the foil for near three hours, \& being a very bad scenting day lost him.

N.B. Grey Carey, dyed this morning.

$$
\text { Wednesday : Nov }{ }^{\mathrm{r}} \cdot 12^{\text {th }} \text {. }
$$

\begin{tabular}{ll|l} 
Sturdy-lump & My Self. & Frosty Face Tom Johnson.
\end{tabular} Slugg ... $\quad . . . \quad$ Joe Budd. $\quad$ Pickadilly David. Sr. William... $\quad$ Will Macey. $\left.\begin{array}{c}\text { Whitestock- } \\ \text { ings ... }\end{array}\right\}$ Jack Row.

Drew East Dean Wood, Charlton Forrest, Bove holts, East Dean Parke, Charlton Cops, Red Cops, Binges, Dawtreys hooks, \& Littleton Bottom, without finding, then wee try'd farm wood \& had a scent, a man say'd he saw the 


\section{Records of the Old Charlton Hunt}

fox, \& every body thought it was a fox, except my Lord De Lawarr, \& Tom Johnson, \& they gave their opinion * it was no fox, however the hounds could do nothing, \& it was a great doubt, if it was a blanc day or not.

Thursday : Feb. $19^{\text {th }}$.

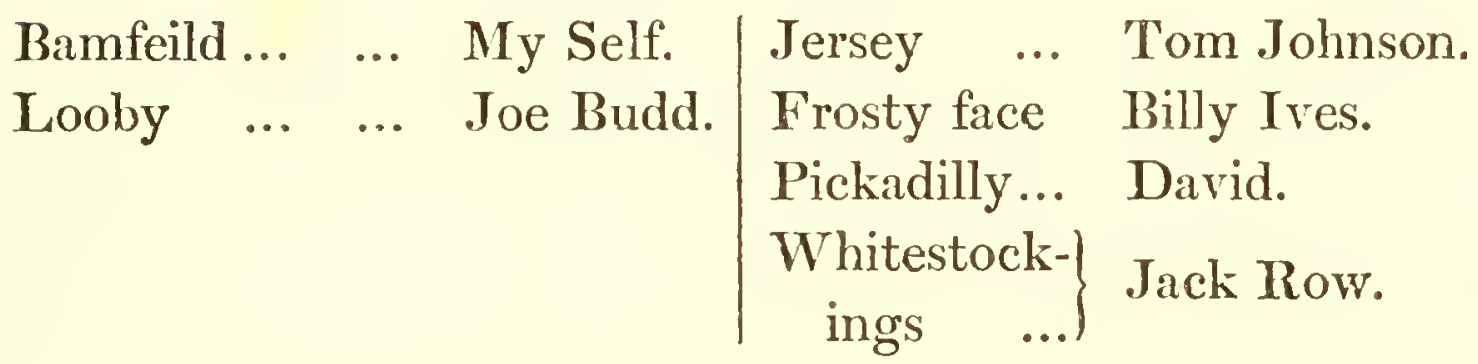

Found in East Dean wood, ran by the Stony house over Dell Coomb, down by Waltham, up through Sellers parke, to North hanger, the Winkin, to Halsted down, through Stricklands Fuzz's, over the Harrow ways, through East Dean Parke, the Boveholts, down crofs the road by East Dean, up to Court hill, East Dean wood, Upper teglees, back by Stony house again to East Dean Wood, Charlton Forrest out at the North East Gate, back through Puntys Cops into the Forrest, to East Dean Wood, upto Stony house over Dell Comb, down by Waltham, up Sellers parke to North Wood, back through Sellers parke crofs the road by Drought house, up through Dell Comb to Stony house, East Dean Wood, through Charlton Forrest to Herring Dean, there the hounds lost the fox \& most of the horses blown up.

* And I am inclined to back their opinion. 


\title{
Records of the Old Charlton Hunt
}

\author{
Tuespay : Feb. $24^{\text {th }}$.
}

Sturdy lump My Self.

Slug ... $\quad \ldots \quad$ Jack Johnson.

$\left.\begin{array}{c}\text { Large Young } \\ \text { horse }\end{array}\right\}$ Joe Budd.

Badger ... Tom Johnson.

Forrester ... Billy Ives.

Post boy ... David.

Spott ... Jack Row.

Found in the Moutenes, butt came to a cheque in the lane, \& upon a cast hitt upon a martin,* \& ran him several rings in the Row Cops, \& treed him, so took off \& came home.

\section{Saturday : Nov ${ }^{r} \cdot 7$.}

\begin{tabular}{|c|c|c|c|}
\hline Sr. Harry & Myself. & Young horse & Tom Johnson \\
\hline $\mathbf{S}^{\text {r. William }}$ & Will Macey. & Harcourt ... & David. \\
\hline $\begin{array}{l}\text { Slugg } \\
\text { Roger }\end{array}$ & $\begin{array}{l}\text { Joe Budd. } \\
\text { Jemy Gardiner. }\end{array}$ & $\begin{array}{l}\text { Whitestock- } \\
\text { ings }\end{array}$ & Jack Ro \\
\hline
\end{tabular}

\section{A Blanck Day.}

Tryed the Valdy, Binderton plantations, Preston Corner, all the Rows \& Coppices about West Dean, Chorlton Coppice, Molcomb fuzzes, \& East Dean parke without finding, butt wee did not go out 'till almost eleven o'clock because of a very hard rain, \& afterwards Fogg in the morning.

* Curious! 


\title{
Records of the Old Charlton Hunt
}

\author{
Munday : Dec .7 .
}

Lord Mayor Myself.

Sr. Harry $\quad .$. Joe Budd.

Bamfeild ... Will Green. Whitestockings

Found in the Ruel, \& ran a fox several rings in the Ruel \& Deans, \& earth'd him in the main earth in Hebedon Coppice, then found an other in Waburton Cops's ran him through Slyndon Parke, over Nore hill Kemps Rough peice, Gumworth, Dowtreys hooks, Glatten Beacon, along the side hill to Bignor Hill, there down the Hill to Bignor Parke, to Red hill, to Burton Parke, the merry feilds they changed, came up Barlavington hill over by 'Twines up to Dawtreys hooks, over the Gumworth, the Rough peice, over Slyndon Down, there the two Biddolphs knock'd up, down by Maye farm, over Madurst Comon down, by the lone beech, to Bignor hill again, \& along the side hills, they came to a cheque in Glatten hanger, there it being almost night wee took off, the hounds fresh, butt all the horses knock'd up except Lord Mayor, the hardest days work for hounds \& horses that I ever saw except the famous long chase upon the [26th $\mathrm{Jan}^{\mathrm{y}}$., 1738]. 


\section{Records of the Old Charlton Hunt}

1742.

Finden : Thursday, Jan. 7.

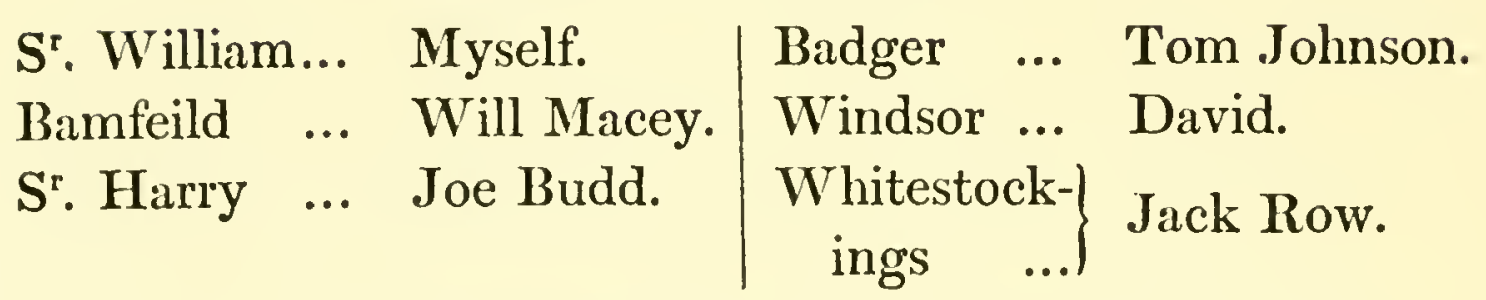

Found in the Juniper bushes, by the Stony Deans, ran through the Stony deans, \& up round Chankberry hill, down to Wiston malthouse, then up by the Lyons banke \& Stenning holt to Mawdelin, over all the Downs away to Applesham, down to the bank of the river, then turn'd up by Lancing windmill, \& then down to South Lancing, \& through the comon feild to the sea beach, there after a falt a curr dog was seen to course her into the sea, \& there swam together, \& then out of the sea over the beach, where they stood at bay, \& the hounds came up \& kill'd her, below the salts farm, a bitch fox.

\section{Tuesday : Nov $\cdot 23^{\mathrm{d}}$.}

\begin{tabular}{lll|lll} 
Bamfeild & ... Myself. & Badger & ... & 'Tom Johnson.
\end{tabular}

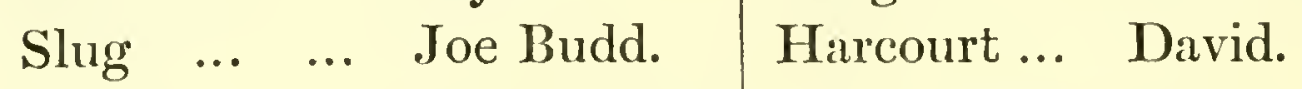
$\left.\begin{array}{lll|ll}\text { Tetlow } & \ldots & \text { Jemy Gard } & \text { Whitestock- } & \text { Whack Row. } \\ \text { Red Robin ... } & \text { Will Macey. } & \text { ings } & . .\end{array}\right)$ Jall

'Try'd Eastdean parke, butt not finding, \& the day excefsively bad wee sent the hounds home to feed. 


\section{Records of the Old Charlton Hunt}

\section{WeDNESDAY : Nov ${ }^{\mathrm{r}} \cdot \mathbf{2}^{\text {th }}$.}

All the same horses as were out the day before.

Found in Charlton Forrest, \& the hounds ran very hard for upwards of seven hours, most part of it in Charlton Forrest \& Eastdean wood; where they ran severall rings, quite round both covers several times, \& once carry'd the scent up almost to the upper Teglees, butt then brought it back again to Eastdean Wood, \& the Forrest, where all the horses knock'd up, \& the day growing very bad, were forced to take off 'tho by farr the greatest number of the hounds were quite fresh.

Wednesday : Dec ${ }^{\mathrm{r}} \cdot \mathbf{2 2 ^ { \mathrm { d } }}$.

\begin{tabular}{lll|lll} 
Sultan & $\ldots$ & My Self. & Badger & $\ldots$ & Tom Johnson. \\
Slug & $\ldots$ & Joe Budd. & Harcourt ... & David. \\
Bamfeild & Jemy Gardiner. & Spott & $\ldots$ & Jack Row. \\
Sturdy & $\ldots$ & Capt $^{\text {n. Legge. }}$ & & & \\
lump. & $\ldots$ & & &
\end{tabular}

The Hounds hitt upon a drag at the bottom of Rooks hill, \& carry'd it through old warren to Preston Corner, butt it growing worse \& worse, wee found that they took it the wrong way, so as it was back to Eastdean Parke, \& a very fine morning, wee went on to Ashling woods \& there found a fox that went over between down Farm \& Adsden, up juniper bottom \& the black bushes, \& the whole length of Bow hill, butt above Chilgrove a fresh fox started up out of 


\section{Records of the Old Charlton Hunt}

a single bush, 22 couple of hounds with Tom Johnson \& Jack Row stuck to the old scent, \& the hounds ran very hard through the Willam wood, the Haslets, \& almost to Stansted forrest, \& back again to the Hasletts \& there as 'Tom Thought ran him to ground, whilst David with 13 couple of hounds \& the rest of the company ran the fresh fox in view by Chilgrove through Phillis wood \& all Lukenor's cops's, the Marloes \& Charlton forrest to Punty's Cops, there, by the help * of Young Battine's hounds they divided, ran hare, rabit, \& every thing butt fox, so wee lost our scent \& came home.

\section{3.}

$$
\text { Thursday : Jan }{ }^{\mathrm{ry}} \cdot 6^{\text {th }} \text {. }
$$

Red Robin My Self.

Lord Mayor Joe Budd.

Tetlow ... Jemy Gardiner.
Bumper ... Tom Johnson.

Castle ... David.

$\left.\begin{array}{l}\text { Whitestock- } \\ \text { ings }\end{array}\right\}$ Jack Row.

Found in the ruel, ran through the deans Hebedon Cops, Bay Coomb, \& try'd Butthill earth, then back again through Bay Coomb over fair mile, \& up again to the ruel, over Arundel parke, crofs the road to Torton Comon \& back again to the Deans, where a grey hound catch'd her, a bitch fox. N.B. 'The grey hound was imediatly hang'd. $\dagger$

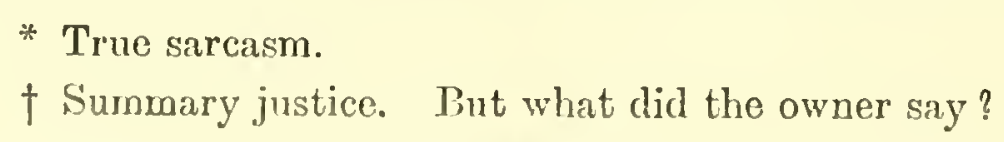

* True sarcasm.

$\dagger$ Sumbary justice. But what did the owner say? 


\section{Records of the Old Charlton Hunt}

Charlton: Wednesday, Jan ${ }^{\mathrm{ry}} .12$.

\begin{tabular}{ll|lll} 
Tetlow ... My Self. & Roger ... & Tom Johnson.
\end{tabular}

Red Robin Jemy Gardiner. Harcourt... David.

Lord Mayor Joe Budd.

Bamfeild... M $\mathbf{M}^{\mathrm{r}}$. Sedgwick. Stockings $\}$ Jack Rowe.

Found in the 'Bove holts, ran through East dean Parke, over the Harroways through Strickland's Fuz's over Hasted's down, by Lord Derby's lavender garden, up through Halnaker parke, \& the wildernefs, the Red-bins, crofs the feilds through Eagly Cops down by Shopwick, through the meadows to Leethorn, \& down to Hunson Farm, there about a quarter of a mile below the farm the hounds had an entapis at him in a thick hedge row, \& view'd him crofs three meadows \& kill'd him, a dog Fox.

'The hounds went to Findon Jan $17^{\text {th }} \&$ return'd to Charlton on the $12^{\text {th }}$ of February, in which time they kill'd four brace of Foxes.

Charlton: Munday, Febry $21^{\text {st }}$.

\begin{tabular}{ll|lll} 
Bamfeild My Self. & Roger & ... & Tom Johnson.
\end{tabular} Tetlow ... Jemy Gardiner. Castle ... David. Slug ... Joe Bud. $\quad$ Spott ... Jack Row.

Found in the ruel, ran through Hebeden Cops's up to the earth at Butt Hill, Through Slyndon parke over the comon to Walburton Cops's, then view'd him back out of the cops, butt the scent did not lye a yard, then over the comon back 


\section{Records of the Old Charlton Hunt}

to Slyndon Parish, \& back through Hebedon Cops to the ruel again then back again through the same Cops, \& over through Bay comb to the earth again upon Butt Hill, butt tho he was view'd several times, the scent lay so very ill that they could not hunt him a yard, \& indeed so bad a scenting day was hardly ever seen, so they came home.

$28 \mathrm{Dec}^{\mathrm{r}}$, 1743.

In the Great Stable. In the Three Stall. In the Huntsmans. Splints.

Bofs.

Slug.

Sheldon.

Bamfeild.

Sturdy lump.

Smith.

Lord Mayor.

Bijoux.

Irish Padd.

Ashburnham.

In the Hack Stable.

Grey Tatler.

Riddolph.

Salamanca.

Roper.
Badger.

Keeper.

Roger.

Dick.

Harcourt.

Castle.

Drewet.

True blew.

Spott.

Whitestockings. 



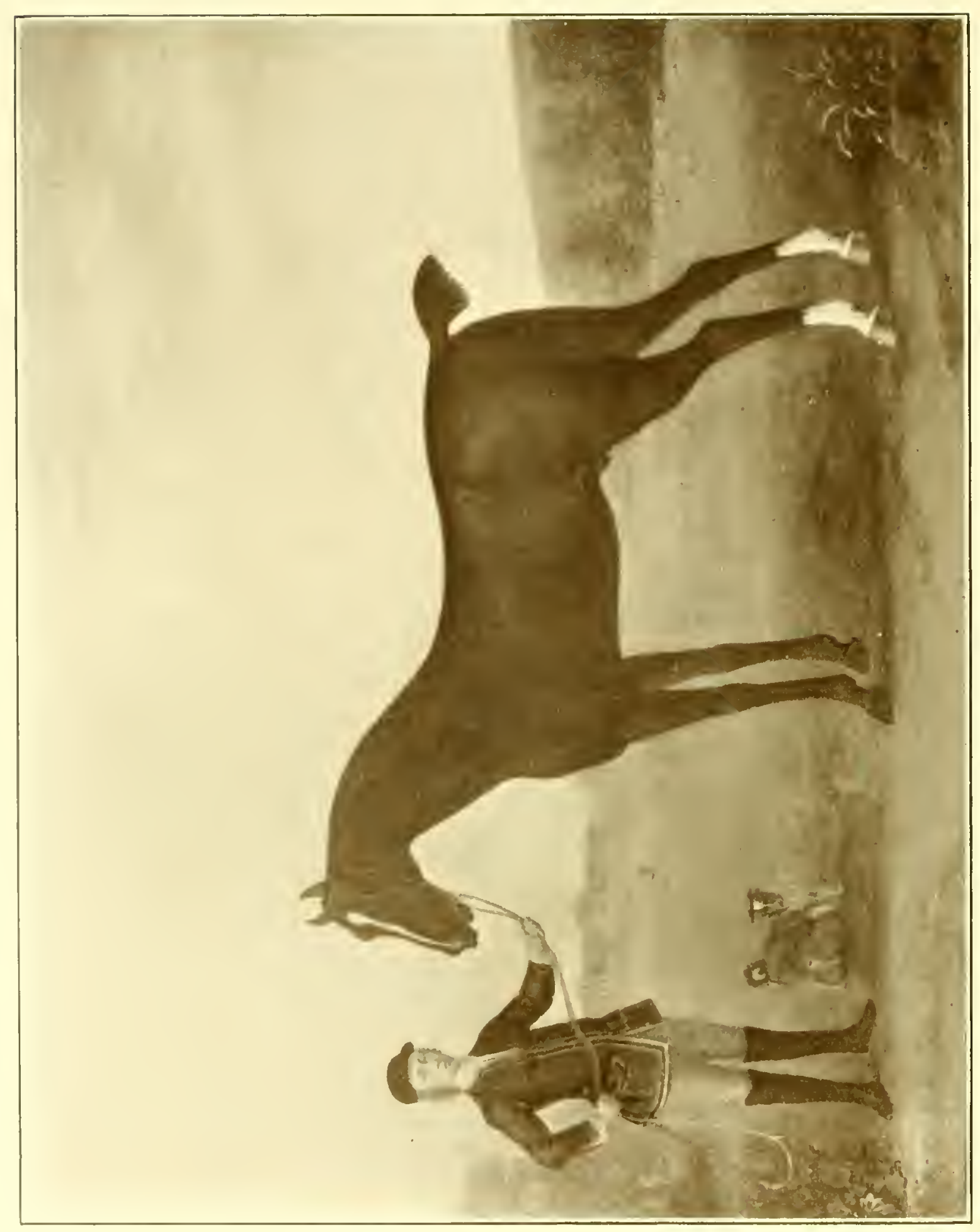

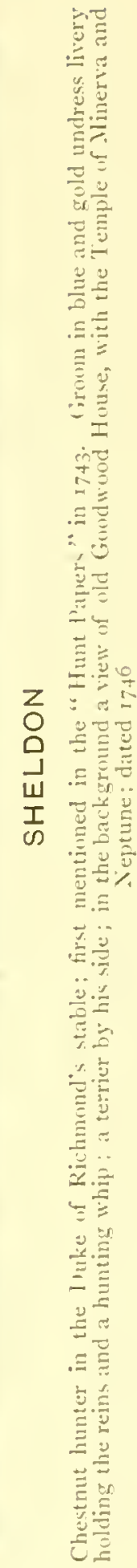




\section{Records of the Old Charlton Hunt}

\section{4 .}

WEDNESDAY : $18 \mathrm{Jan}^{\mathrm{ry}}$.

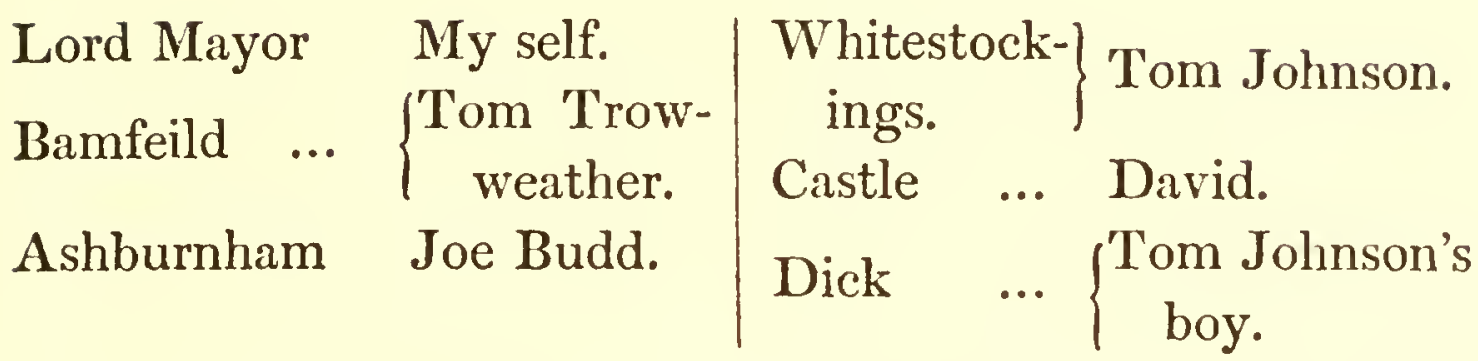

A fox stole off from the merryfeilds, \& was halloed by $\mathbf{M}^{\mathrm{r}}$. Orms north gate of his avenue, so the hounds were laid on there, \& they ran it very hard, up the steep part of Graffam hanger, over the Teglees to Randals bottom, crofs the road up to the Binges, \& from thence to Dawtreys hooks, over Waltham Comon by the lone beech, \& up to Houghton Pound, \& to Preist comb there the Fox headed \& turn'd back \& ran all the side hills to Farm Wood, North hanger \& Barlavington hanger, there he went down the hill \& ran by Sutton to Bignor parke \& Waltham Parke, \& then back to Farm wood where he went to ground in the main earth, so he could not be dugg.

I went to London \& the hounds were out butt three times as it was a hard frost, \& in the three times of going out they did not find once, or had even a touch of a fox ; they beat twice below the hills by Midhurst, feilder's fuzz's, Burton, \& Bignor Parke \& once at Chidham. 


\section{Records of the Old Charlton Hunt}

\section{Munday: $10 \mathrm{Dec}^{\mathrm{r}}$.}

Foxhunter.

$L^{d}$. Mayor.

Sturdy Lump.

Harcourt ... Jack Woods.

Castle ... ... David.

Spott ... ... Jack Row.

D. Richmond.

D. St. Albans.

Ld. Harcourt.

Sr. John Miller.

$\mathrm{M}^{\mathrm{r}}$. Jennison.

Mr. Pauncefort.

Mr. Dayrolle.

Lieut ${ }^{\text {nt }}$. Fletcher. $\mathrm{M}^{\mathrm{r}}$. Tho. Hill.
Mr. Johnson of Chichester.

John Woods.

David Briggs.

John Row.

Found in the Valdy, ran over the Valdy corner, Goodwood warren the upper corner of Molecombe, to East dean Parke, several rings there then a hallow away between the two parks, crofs the east dean lane \& up the forty acres, over the side of North down, crof's to Laving down over the top of it, then turn'd short to Broadham, singleton forrest, \& over Cocking high way through the Marlo's, Hackingplace, Cocking Coney Coppice, then by Lewknors Coppice lowergate, \& over the bottom of Collar down, crofs the grounds to the warren, all through West dean warren, headed into Crows hole grounds, crofs Binderton lane, through Preston Farm yard up over West-dean down, through old warren, down through the grounds, close by Singleton, up by the hatt, \& Pine pitt hanger, through ware hill hanger, up the long slip, \& Cocking Coney Coppice in Cocking Warren, crofs the warren, then up the bottom of it to Sadler's Fuzze, over the Hill by Linch hanger, then along the side hill, to the bottom of Cocking Warren again, (where the fox was view'd) crofs it, up to Cocking Coney Coppice again, the Marlows, crofs Cocking Highway, up through Singleton \& Charlton Forrest to Eastdean wood 


\section{Records of the Old Charlton Hunt}

great gate, then along the side hills, above Woollavington, Duncton Chalk-pitt, Barlavington Hanger, \& North Combe, above which in a hedge Row they kill'd him, a Dog Fox.

N.B. the chase lasted 5 hours \& 11 minutes, of which above 2 hours of it was cold hunting, almost every horse knock'd up, however, David, L'. Harcourt, S'. John Miller, Mess $^{\text {rs }}$. Pauncefort, Dayrolle, Fletcher \& Hill, were in at the death.

\section{Thursdar : 20 Dec .}

The Duke of Richmond was in London.

$$
\begin{aligned}
& \text { Jack Woods ... Harcourt. } \\
& \text { David ... } \quad \ldots \quad \text { Splints. } \\
& \text { Jack Row } \quad . .\left\{\begin{array}{l}
\text { White- } \\
\text { stockings. }
\end{array}\right.
\end{aligned}
$$

D. of $\mathrm{S}^{t}$. Albans.

Mr. Jeñison.
| MI $\mathrm{r}$. Hill.

MI. Pauncefort.

Found in the Willam wood, went up the Hill to the Innums, headed back \& went over Stoughton down to Ashling woods, stoke Coppices, the Rifles, \& the Broil, there ran him an hour \& a half in one Coppice \& kill'd him a Dog fox. 


\title{
Records of the Old Charlton Hunt
}

\section{MONUMENTAL INSCRIPTION AT SINGLE'TON CHURCH IN SUSSEX}

\author{
Ngar this Place lies interred
}

\section{THOMAS JOHNSON}

who departed this Life at Charltow

Deceniber $20^{\text {th }}, 1744$.

From his Early inclination to Fox Hounds

He soon became an experienced Huntsman

His knowledge in this Profession wherein ile

Had no superior aNd hardey aN Equal,

JoIned to his Honesty in every other particular,

RECOMMENDED HIM TO TIIE SERVICE AND GAIN'D

Him the approbation of several of the Nobility

and Gentry. Among these were the LORD CONWAY

EARL OF CARDIGAN, The LORD GOWER, The DUKE

OF Marlborough and the Hovourable $M^{\mathrm{R}}$. SPENCER.

The Last Master whom He Served, and in witose Service

HE DIED WAS CHARLES DUKE OF RICHMOND

LENOX AND AUBIGNY, who erected this Monument

To the Mimory of a gOOd and faithifull servant

As a REWARD TO THE DECEASED,

And an incitement to tile Living.

Go and do thiou Likewise, St. Luke Chap. x. ver. xxxvit.

On a slab below :-

Mcre Jolnson lies, What Hunter can deny

Old honest TOMI the Tribute of a Sigh,

Deaf is that Ear, which canght the op'ning Sound,

Dumb is that Tongue, which chear'd the Hills around

Unpleasing Truth, Death hunts us from our Birth

In view; and Men, Like Foxes, take to Earth. 



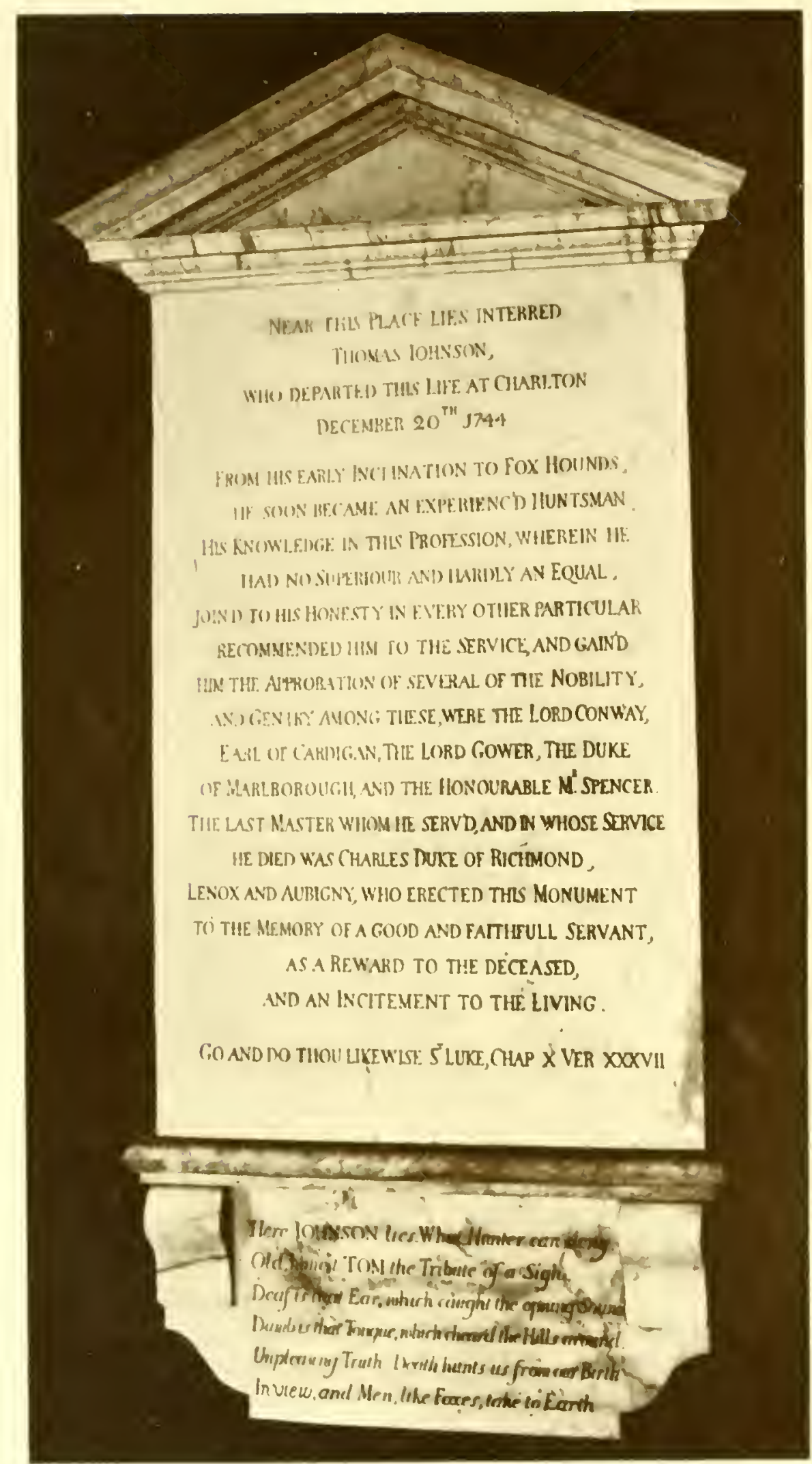

MURAL TABLET PLACED IN SINGLETON CHURCH TO THE MEMORY OF TOM JOHNSON BY THE SECOND DUKE OF RICHMOND 


\section{Records of the Old Charlton Hunt}

\section{TOM JOHNSON'S DEA'TH}

$\mathbf{M e m}^{\mathrm{m}}$.

$$
\text { On Thursday, } 20 \text { Dec } \text {., 1744. }
$$

Thomas Johnson dyed at Charlton \& was buryed in the Church at Singleton.

\section{FRYDAY : 28 Dec .}

\begin{tabular}{ll|lll}
$\begin{array}{l}\text { D. of Rich- } \\
\text { mond }\end{array}$ & Bamfeild. & $\begin{array}{l}\text { Jack Woods } \\
\text { David }\end{array}$ & $\ldots$ & Harcourt. \\
$\begin{array}{l}\text { Jem. Gardiner Slug. } \\
\text { Hobson }\end{array}$ & Jack Row & Sturdy lump. & $\ldots$ & Castle. \\
& & & Spott.
\end{tabular}

D. St. Albans.

$M I^{r}$. Pauncefort.

Whilst the hounds were beating of red Coppice a fox was hallow'd out of a hedge row by East dean lane; \& as wee were going to lay the hounds upon it, they crofs'd upon a drag \& found in East dean parke \& ran down the feilds between Eastdean \& Charlton, then turn'd to Eastdean Street where the fox was hollow'd \& by their seing a collor $\&$ linke of a Chain about his neck, it proved to be Lord George's* fox, butt the hounds ran him so hard that they could not be taken of, \& ran him into the above holts, where wee certainly changed to a fresh fox who went acrofs North hanger, Sellers parke, all along the West side of long down, through Earthham bushes, \& the feilds to Boxgrove comon, crofs Teen Wood, by Crocker Hill, crofs the high

* The Duke's 2nd son, aged 7. 


\section{Records of the Old Charlton Hunt}

road \& meados by my Lady Derbys decoy, where wee thinke wee changed again, then to Aldenburn \& from thence through Eastergate, to Yapton, \& from thence down to Bilsom, \& down to Elmor Coppices by the sea side, \& then turn'd up to Bourn Wood where he being a great way before them wee lost him.

1745.

Charlton: Munday, Jan ${ }^{\mathrm{ry}} .27$.

went out.

John Smith.

D. Richmond Little John. John Woods.

Harlequin. John Row.

Thomas Perrin.

Found in East Dean wood, at least three brace of foxes, so could have no sport for the hounds divided, one was run to ground, one kill'd down by the forrest house, a dog fox, \& another kill'd down by Graffam as said butt never brought home, \& another took a ring round the Teglees, \& all along the side hills from the upper teglees, to Charlton Forrest \& so back to east dean wood where wee conjectured him also gon to ground, so gave the fox that was kill'd by a bardle of hounds at the forrest house to be worry'd by the pack, the first that was run to ground was allso dugg out of a Rabbitt-borough, a dog fox, butt as the hounds had blood enough, wee saved him. 


\section{Records of the Old Charlton Hunt}

\section{Wednesday $: 26^{\text {th }} \mathrm{Feb}^{\mathrm{ry}}$.}

went out.

D. Richmond Little John.

\begin{tabular}{ll|ll} 
& Bamfeild. & John Row ... & Spott. \\
L. Harcourt & Lord Mayor. & Tho . Perrin & Castles.
\end{tabular}

D. St. Albans.

Lord Hartington.

Lord Dalkeith.

$$
\begin{array}{l|l}
\text { Lord Lincoln. } & \text { MIr. Fisher. } \\
\text { Sr. John Miller. } & \text { MIr. Taaf. } \\
\text { MIr. Jennison. } &
\end{array}
$$

Found in East Dean wood where there were severall foxes on foot \& the hounds in severall parcells, butt the best of them ran one along the side Hills to Lavington, \& along the bottom there, then up Barlarington hanger, \& down again to Sutton, butt that was a fresh fox \& the hunted one went to ground in Farm-wood, where the Tarryers lay at her \& (after the hounds were taken of to go back to East dean Wood where six or seren couple of old hounds were running,) some country men got her out \& brought her home, \& she was thrown to the hounds in Kennell, a Bitch Fox. 
CHAPTER VII

\section{EXPENSE OF THE HUNT IN I745, 1746 , ETC.}

Anstract of the Expence of the Hunt in 1745.

$$
\text { New Forest. }
$$

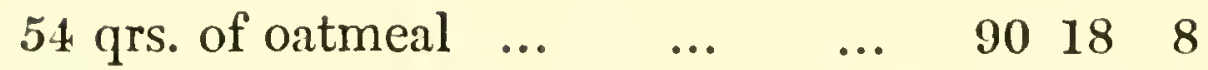

$\begin{array}{llllllll}57 & \text { qrs. of oats } & \ldots & \ldots & \ldots & 38 & 13 & 0\end{array}$

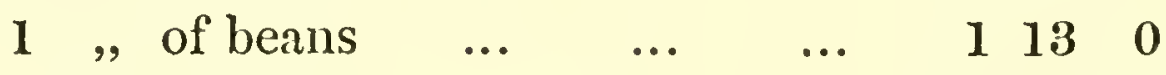

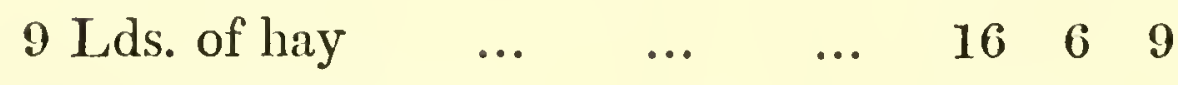

$\begin{array}{llllllll}33 & \mathrm{~L} \text { ds. of Straw } & \ldots & \ldots & \ldots & 26 & 12 & 0\end{array}$

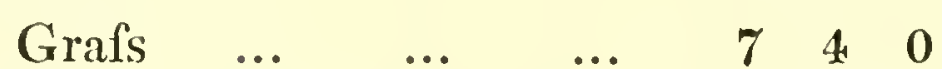

$\begin{array}{lllllllllll}\text { Flesh } & 20 & 13 & 0 & \text { Wood } & 17 & 0 & 0 & 37 & 13 & 0\end{array}$

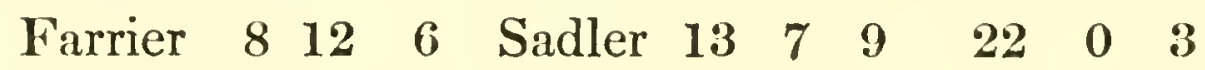

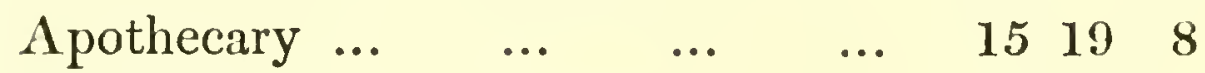

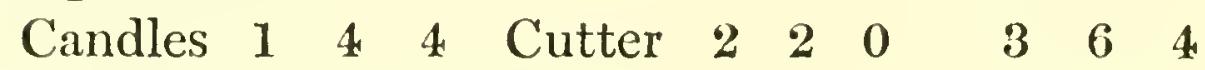

$\begin{array}{lllllll}\text { Earth Stoppers } & \ldots & \ldots & \ldots & 2 & 17 & 0\end{array}$

$\begin{array}{lllllll}\text { Huntsman's bills } & \ldots & \ldots & \ldots & 19 & 2 & 6\end{array}$

Bricklayers \& Carpenters $\quad \ldots \quad \begin{array}{llllll} & \ldots & 3 & 11 & 1\end{array}$

$\begin{array}{llllllll}\text { Odd things } & \ldots & \ldots & \ldots & \ldots & 3 & 17 & 0\end{array}$

$\begin{array}{lllllll}\text { Half a year's wages ... } & \ldots & \ldots & 90 & 9 & 0\end{array}$ 


\section{Records of the Old Charlton IIunt}

\section{Charlton.}

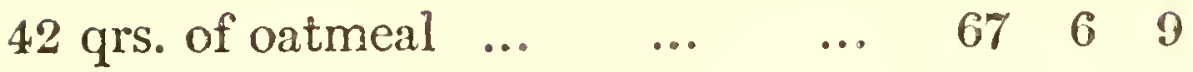

$\begin{array}{llllllll}50 & \text { qrs. of oats } & \ldots & \ldots & \ldots & 25 & 1 & 6\end{array}$

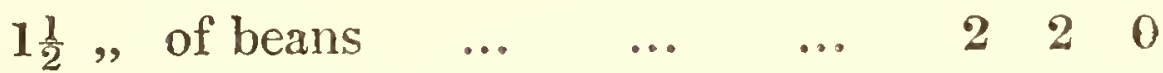

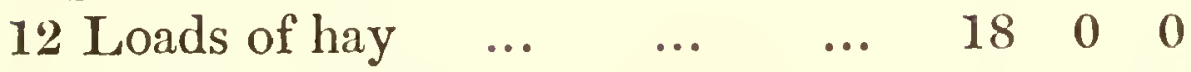

$\begin{array}{lllllll}25 \frac{1}{2} \text { Loads of Straw } & \ldots & \ldots & 15 & 6 & 0\end{array}$

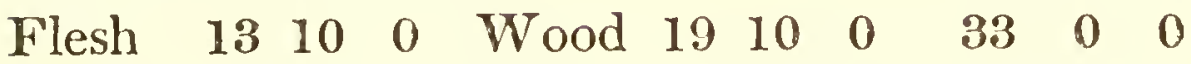

$\begin{array}{lllllllllll}\text { Farrier } & 5 & 18 & 3 & \text { Sadler } & 4 & 7 & 3 & 10 & 5 & 6\end{array}$

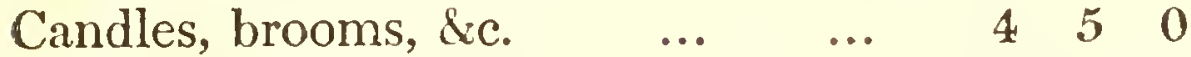

$\begin{array}{llllll}\text { Earth Stoppers \& Warreners } & \ldots & 66 & 17 & 0\end{array}$

$\begin{array}{lllllll}\text { Huntsmen's bills } & \ldots & \ldots & \ldots & 7 & 6 & 6\end{array}$

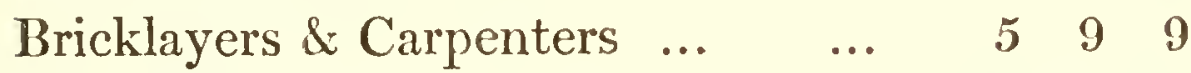

$\begin{array}{llllllll}\text { Hounds } & \ldots & \ldots & \ldots & \ldots & 40 & 17 & 10\end{array}$

$\begin{array}{llllllll}\text { Horses } & \ldots & \ldots & \ldots & \ldots & 6 & 6 & 0\end{array}$

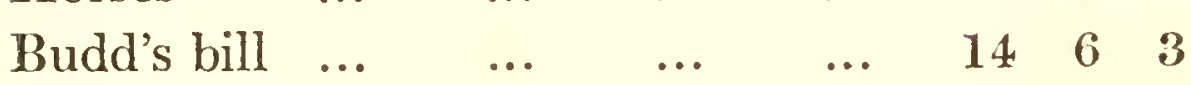

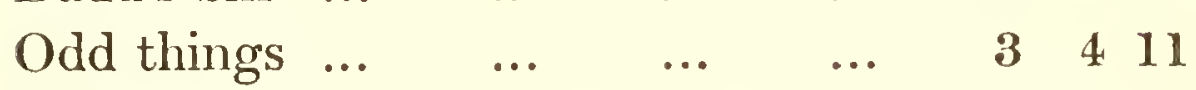

$\begin{array}{lllllll}\text { Half a year's wages ... } & \ldots & \ldots & 101 & 5 & 6\end{array}$

$\begin{array}{lll}421 & 0 & 6\end{array}$

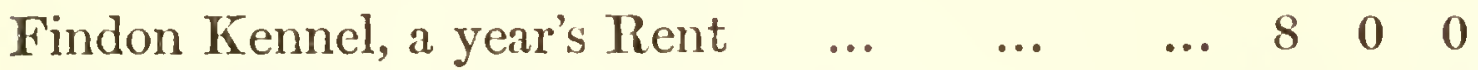

$\begin{array}{lllllllll}\text { Uppark bills } & \ldots & \ldots & \ldots & \ldots & \ldots & 66 & 5 & 4\end{array}$

$875 \quad 9 \quad 1$

The expence of ten Hunters for

His Grace's own use for one year including Wages, Board-wages \&

$\begin{array}{llllllllll}\text { Liveries } & \ldots & \ldots & \ldots & \ldots & \ldots & & 418 & 14 & 4\end{array}$ $\begin{array}{lllllll}\text { To } 5 \text { Liveries for the Hunt } \quad \ldots & \ldots & 35 & 0 & 0\end{array}$

Total $\quad £ 1329 \quad 3 \quad 5$ 


\section{Records of the Old Charlton Hunt}

Abstract of the Expence of the Hunt in 1746.

New Forest.

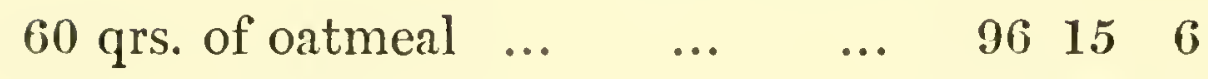

$\begin{array}{llllllll}85 & , \text {, of oats } & \ldots & \ldots & \ldots & 52 & 16 & 0\end{array}$

$\begin{array}{llllllll}6 & \text {, } \text { of beans } & \ldots & \ldots & \ldots & 8 & 6 & 0\end{array}$

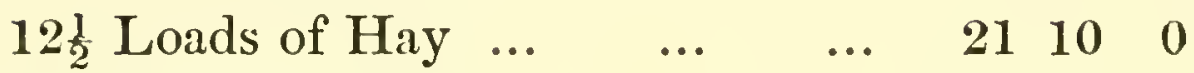

$\begin{array}{lllllll}36 & \text { Loads of Straw ... } & \ldots & \ldots & 28 & 16 & 0\end{array}$

$\begin{array}{lllllllllll}\text { Grafs } & 8 & 8 & 0 & \text { Flesh } & 23 & 16 & 0 & 32 & 4 & 0\end{array}$

$\begin{array}{llllllllll}\text { Wood } & 21 & 0 & 10 & \text { Candles } 1 & 0 & 6 & 22 & 1 & 4\end{array}$

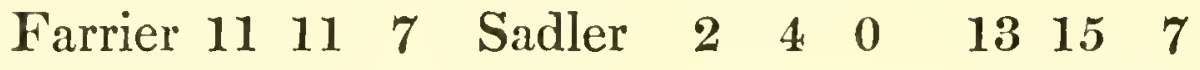

$\begin{array}{llllllll}\text { Apothecary } & . . & \ldots & \ldots & \ldots & 2 & 16 & 8\end{array}$

Earth Stoppers 5180 Cutter 11100000

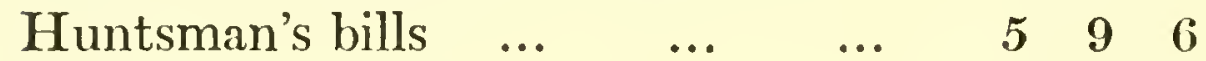

Bricklayers, Carpenters, \&c. $\quad \ldots \quad \ldots \quad 2 \quad 2 \quad 17 \quad 9$

$\begin{array}{lllllllll}\text { Carriage } 3 & 3 & 0 & \text { Odd things } 1 & 13 & 11 & 4 & 16 & 11\end{array}$

$\begin{array}{lllllll}\text { Half a year's wages ... } & \ldots & \ldots & 83 & 14 & 0\end{array}$ 


\section{Records of the Old Charlton Hunt}

\section{Charlton.}

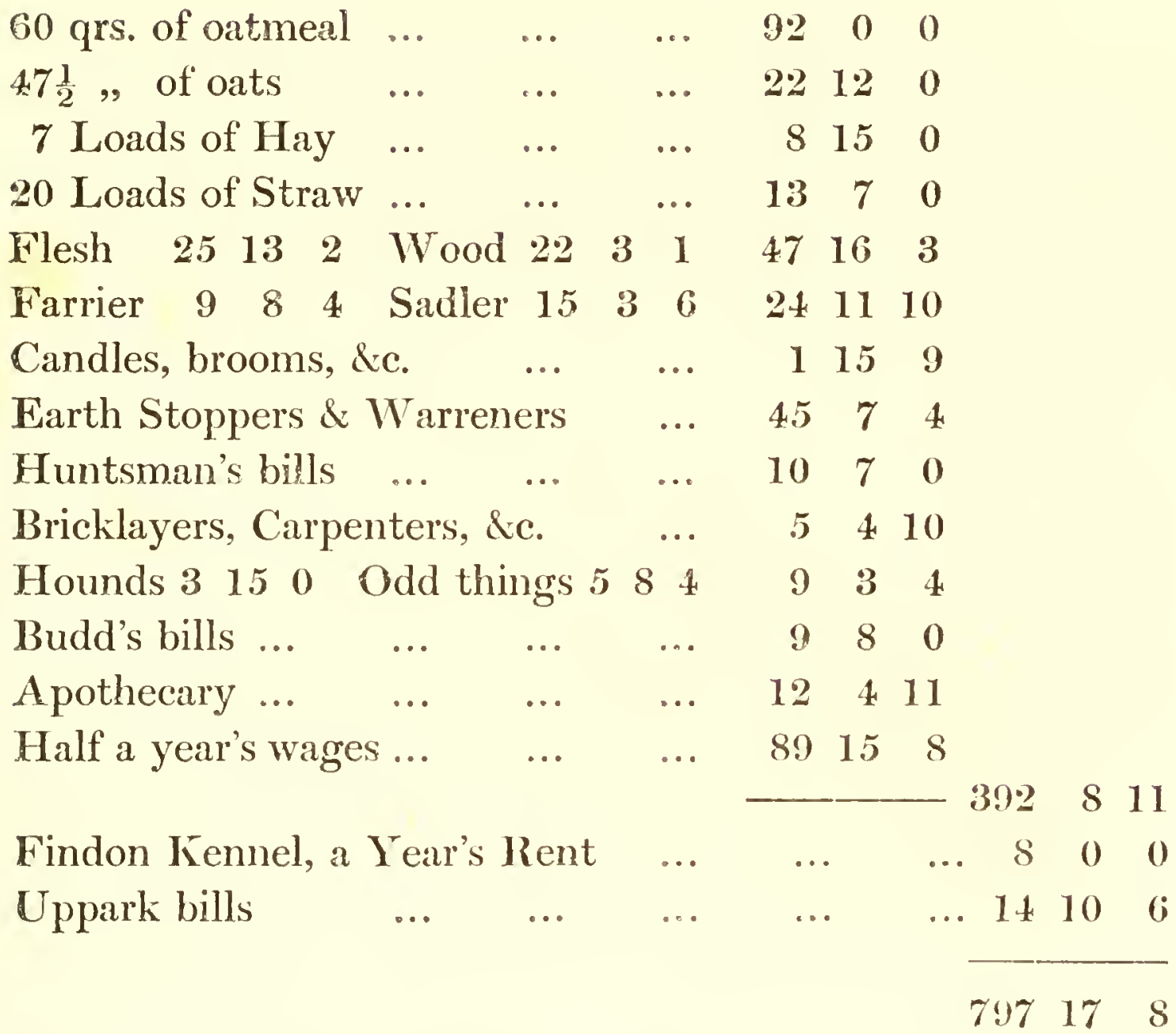

The expence of ten Hunters for His Grace's own use for one year including Wages, Board-wages \& Liveries $\ldots$...

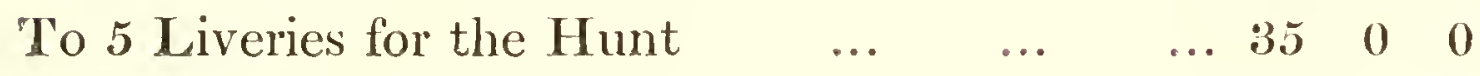

'Total $\quad \mathfrak{E} 1251 \quad 12 \quad 0$ 


\section{Records of the Old Charlton Hunt}

'Io those who are familiar with the aspect of Charlton at the present day, the following details will be interesting.

It is indeed hard to imagine that accommodation had to be provided for no less than 143 hunters, with their attendant crowd of grooms and helpers, for out of all this long list of Quarters which existed in $\mathbf{1 7 4 7}$ there remain but two which can be located with any degree of certainty-the Fox Inn and the hunting-box of the Duke.

John Budd, the composer of the 'Sussex Garland' of sporting songs, appears to have figured prominently in the provision of board and lodging for man and beast, but of his hospitable roof no trace remains.

\section{QUAR'TER FOR HORSES, 1747, A'T CHARLTON}

$$
\text { Quartered } 7^{\text {th }} \text { Feb., } 174 \frac{7}{8} \text {. }
$$

Duke of Richmond

$M^{\mathrm{r}}$. Brudenell

$M^{r}$. Pauncefort $\quad \ldots \quad \ldots$

Duke of Grafton ... $\ldots$

$\mathrm{S}^{\mathrm{r}}$. Will ${ }^{\mathrm{m}}$. Corbett ... $\quad \ldots$

Coll. Honywood ... ...

$\mathrm{S}^{\mathrm{r}}$. Mathw. Featherstone
$\mathrm{M}^{\mathrm{r}}$. O'brien

Lord Lincoln $\quad \ldots, \ldots$

$\left.\begin{array}{lll}\text { Lord Vincoln } & \ldots & \ldots \\ \text { Coll. Carpenter } & \ldots & \ldots\end{array}\right\}$ at Lord Lincoln's.

Lord Harcourt $\quad \ldots \quad \ldots$ at Lord Harcourt's.

Lord Downe $\quad . . \quad$... at Lord De Lawarr's.

Lord 'Trentham ... $\quad . . \quad$ at Lord Effingham's.

Lord Ravensworth

$\mathbf{M}^{\mathrm{r}}$. Crawley

Mr. Varey ...

Coll. Waldgrave

Mr. Fisher ...
... at Moll Rudd.

$\ldots\}$ at $\mathrm{L}^{\mathrm{t}}$. Gen" ${ }^{11}$. Hawley's.

$\ldots\}$ at Dearlings. 



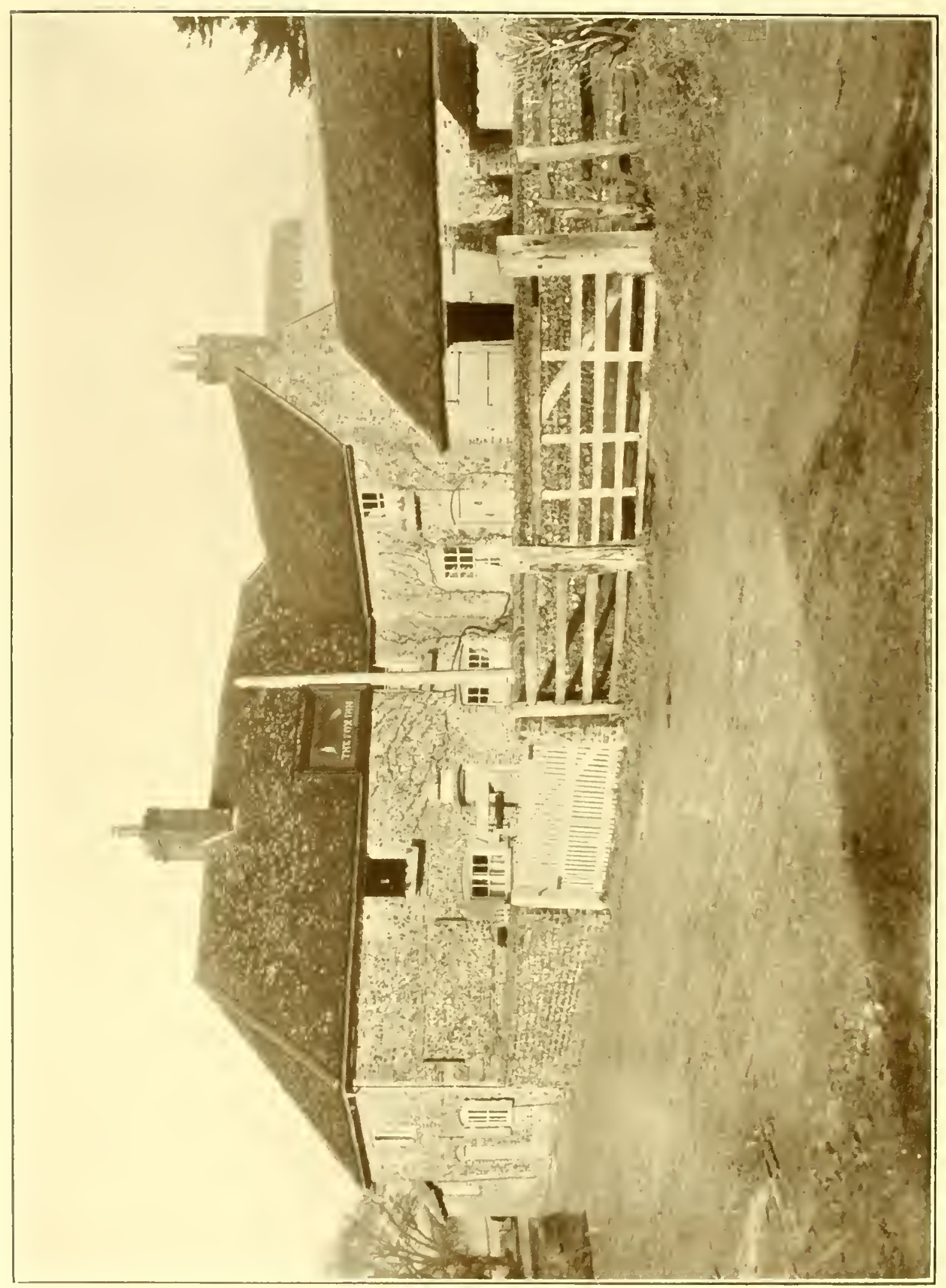

$\begin{array}{ll}2 & \vdots \\ 0 & \vdots \\ r & \vdots \\ \alpha & 0 \\ 1 & 0 \\ 0 & 0\end{array}$ 


\section{Records of the Old Charlton Hunt}

\begin{tabular}{|c|c|c|c|}
\hline $\begin{array}{l}\text { Oates, hay is } \\
\text { straw to be }\end{array}$ & Quarters & For & Horses. \\
\hline furnished from & Duke of Richmond & $\left.\begin{array}{l}8 \\
3\end{array}\right\}$ & in his own stables. \\
\hline Goodwood & & $\begin{array}{r}10 \\
8\end{array}$ & $\begin{array}{l}\text { in huntsman's stables. } \\
\text { Hacks at } \mathbf{M}^{\mathrm{r}} \text {. Bilsons. }\end{array}$ \\
\hline & Duke of Grafton ... & $\begin{array}{l}10 \\
14\end{array}$ & $\begin{array}{l}\text { at } \mathbf{M}^{\mathrm{rs}} \text {. Hayley's stable. } \\
\text { at Cliitty's. }\end{array}$ \\
\hline & $\mathrm{S}^{\mathrm{r}}$. Will ${ }^{\mathrm{m}}$. Corbett & 7 & at Chitty's. \\
\hline & Coll. Honywood ... & 5 & $\begin{array}{l}\text { in } \mathrm{M}^{\mathrm{r}} \text {. Dayrolle's } \\
\text { stable. }\end{array}$ \\
\hline & $\begin{array}{l}\text { S }^{\mathrm{r}} \text {. Mat } \\
\text { ston. Feather- }\end{array}$ & 6 & $\begin{array}{l}\text { in } \mathrm{M}^{\mathrm{r}} \text {. Iremonger's } \\
\text { stable. }\end{array}$ \\
\hline John Budd & $\mathbf{M}^{\mathrm{r}}$. Obrien $\quad \ldots$ & 6 & at Lord Hallyfax's. \\
\hline & $\left\{\begin{array}{l}\text { Lord Lincoln } \\
\text { Capt }^{n} \text {. Carpenter ... }\end{array}\right\}$ & 8 & at Lord Lincoln's. \\
\hline & Lord Donne & 8 & at Lord De Lawarr's. \\
\hline & $\left\{\begin{array}{ll}\mathbf{I}^{\mathrm{r}} \text {. Crowley } & \ldots \\
\mathbf{M}^{\mathrm{r}} \text {. Varey } \ldots & \ldots\end{array}\right\}$ & 8 & at L $\mathrm{L}^{\mathrm{t}}$. Gen ${ }^{11}$. Hawley's. \\
\hline & MI ${ }^{\mathrm{r}}$. Brudenell $\quad \ldots$ & 4 & at The Fox. \\
\hline Glover & $\left\{\begin{array}{c}\text { Lord Trentham } \ldots \\
\text { Coll. Waldgrave ... }\end{array}\right\}$ & 8 & at Glover's. \\
\hline & $\left\{\begin{array}{l}\text { Lord Harcourt } \ldots \\
\text { Lord Ravensworth }\end{array}\right\}$ & 6 & at Lord Harcourt's. \\
\hline Dearling & $\left\{\begin{array}{l}M^{\mathrm{r}} \text {. Vane ... } . . \\
\text { or Ld. Trentham. } \\
\mathbf{M}^{\mathrm{r}} \text {. Fisher, \& who }\end{array}\right.$ & 8 & at Lord Effingham's. \\
\hline & he pleases & 16 & at Dearling's. \\
\hline & & 143 & \\
\hline
\end{tabular}




\section{Records of the Old Charlton Hunt}

'THE EAR'TH-STOPPERS ACCOUN'T OF YOUNG FOXES GIVEN IN MAY 30,1747

A litter in Eastdean Wood.

A litter in the Marlows.

A litter in farmwood.

A litter in North Comb.

A litter in the Sheepwash Earth.

2 litters in Priest Comb \& the Oars.

A litter near Bignor Park.

A litter in the William.

A litter in the Haslets.

A litter in Stoke Lithe.

They believed there were a great many more in other places, but the above is all they are certain of. 


\section{CHAPTER VIII}

\section{VARIOUS HUNTING BILLS OF FIRST AND SECOND DUKES OF RICH- MOND'S HUNTING DIARY}

\section{A SADLER'S BILL OF 'THE FIRS'T DUKE OF RICHMOND, DATED 1705}

[It is interesting to note that " a Larg 'Tand hoggs Leather hunting Saddle \& flapps stiched with gould wire Sterrips and Leathers \& guirths," was only priced at $£ 15$ s., somewhat different to what we have to pay nowadays.]

His Grace the Duke of Richuond his Bill

$$
\text { March } \mathrm{Y}^{\mathrm{E}} 10,1705 .
$$

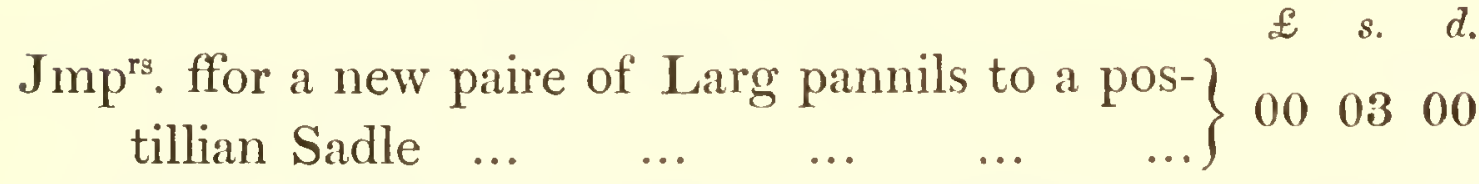
ffor a new paire of "Sterrips" and Leathers... 000306

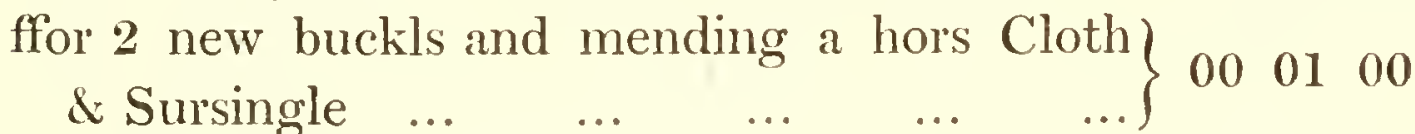
ffor a Long postillian whip with a silk Lash $\quad 00 \quad 0500$ ffor a new Sham pad Sadle with Sterrips and

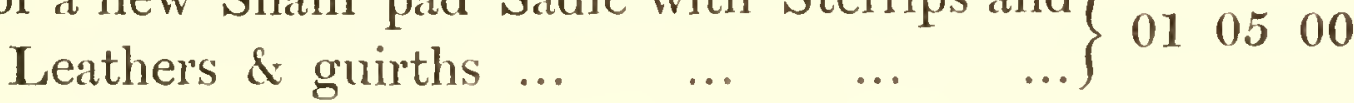
Ap ${ }^{\mathrm{Il}} .10$.

ffor a new paire of houlsters \& straps and

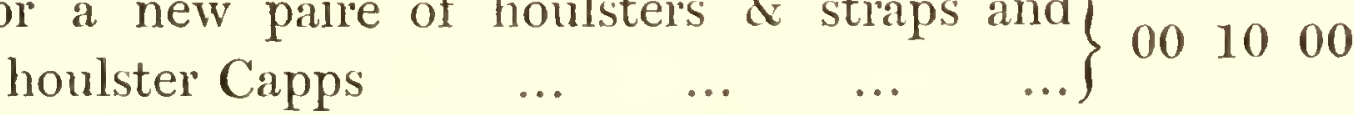
ffor a sett bridle and brestplate \& Crupper $\ldots 0007 \quad 06$ 


\section{Records of the Old Charlton Hunt}

ffor a Cannon mouth bit \& bosses

ffor Leather and new Lynings and Stiffining

and macking 2 Luivre hoosses and bags of 010800 yellow Cloth ... $\quad \ldots \quad \ldots \quad \ldots \quad \ldots \quad \ldots$, ...

ffor a new paire of pannils to a pad Sadle $\quad . .0000300$ ffor a new paire of houlsters \& Straps \& houlster Capps

001000 ffor a new paire of Sterrips and Leathers \& guirths $00 \quad 0506$ ffor a Cannon mouth bitt \& bosses $\quad \ldots \quad 1 \quad \ldots \quad 0006 \quad 06$ ffor a new Sett bridle and brestplate \& Cruper 000706

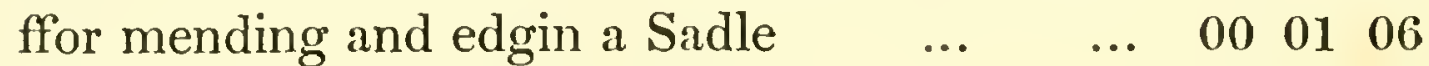
ffor 3 new paire of Cloack Strapps $\quad \ldots \quad \ldots 000200$ ffor a Larg Tand hoggs Leather hunting)

Sadle \& flapps stiched with gould $w^{\text {re }}$ Sterrips 010500 and Leathers \& guirths

ffor a new paire of houlsters Lyned $\mathrm{w}^{\mathrm{re}}$ bayds $\&$ Strapps

000800

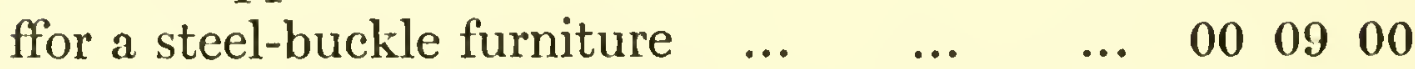
ffor 6 yards of broad Silk orice Lace \& $6 \mathrm{y}^{\mathrm{ds}}$ of narrow orice for the hoos \& baggs ... $00 \quad 0900$ ffor Lyning for $\mathrm{y}^{\mathrm{e}}$ hoose \& baggs \& Lacing \& macking them up 001806 May $\mathrm{y}^{\mathrm{e}} 18$.

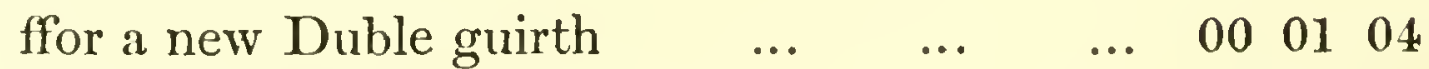

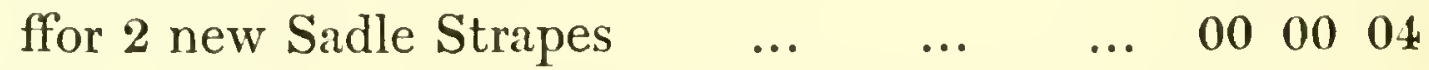
$\left.\begin{array}{llllll}\text { ffor Stuffing and Cleaning and mending } & 2 \\ \text { Sadls \& houlsters and furnitures } & \ldots & \ldots\end{array}\right\} 000306$ ffor stuffing and mending a wattering Sadle... 000106 $\begin{array}{lllllll}\text { ffor a new Duble guirth } & \ldots & \ldots & \ldots & 00 & 01 & 04\end{array}$ 


\section{Records of the Old Charlton Hunt}

$\operatorname{Aug}^{\text {st }} \cdot \mathrm{y}^{\mathrm{e}} \mathbf{2 7}$.

ffor a tand hoggs Leather hunting sadle \&

flapps 'Trymed $w^{\mathrm{re}}$ gould $\ldots \quad \ldots \quad \ldots$...

$£$ 8. d.

011000

ffor a paire of princes Mettell hunting Sterrips $00 \quad 06 \quad 00$ ffor a paire of Sterrip Leathers and guirths $\ldots 000300$ ffor Silk and Lyning and making up a hoose

and baggs and Lacing it $\ldots . \quad \ldots \quad \ldots\} 001800$

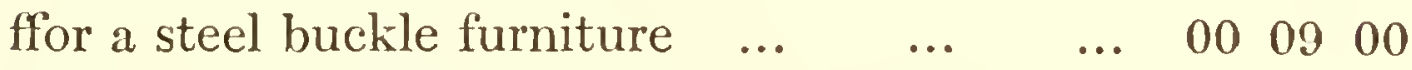
ffor a new paire of houlsters Lyned $w^{\text {le }}$ bayes

and strapps and a paire of houlster Capps ... $\} \begin{array}{lll}00 & 10 & 00\end{array}$

ffor a Cannon mouth bitt $w^{\text {le }}$ princes mettell

bosses ...

\} $\begin{array}{llll}00 & 07 & 00\end{array}$

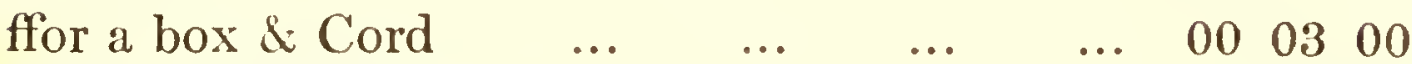

ffor a Larg Itallian pad Sadle $w^{\text {te }}$ a Rushey

Leather Scuirt and a Cloth Seat $\ldots . \quad \ldots\} 01 \quad 1500$ June $\mathrm{y}^{\mathrm{e}} 28$.

ffor a paire of princes mettell Sterrips $\quad \ldots \quad 000900$ ffor a paire of Sterrip Leathers \& a Trible fine $\left.\begin{array}{cccc}0 . . & \ldots\end{array}\right\} 00$

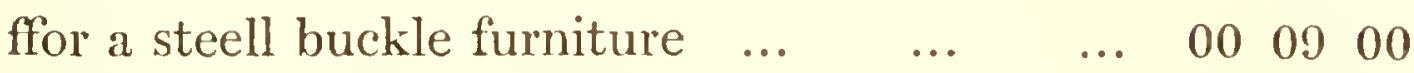
ffor a new paire of princes mettell bosses to $\left.\begin{array}{llllllll}\mathrm{y}^{\mathrm{e}} \text { bitt ... } & \ldots & \ldots & \ldots & \ldots & \ldots\end{array}\right\} 000200$

$\left.\begin{array}{ccccccc}\text { ffor a new paire of houlsters } & \& & \text { straps } & \& \\ \text { houlster Capps } & \ldots & \ldots & & \ldots & \ldots\end{array}\right\} 00 \quad 0900$ ffor pinking the Cloth and new Lyning and macking up a Cloth hoose \& baggs... $\quad . .\} 00 \quad 16 \quad$. ffor a Larg Sacking hors Cloth \& body Rowler 001300 ffor a best Cooller $w^{\text {ie }}$ Duble Raines 'Throat bands \& frunts 


\section{Records of the Old Charlton Hunt}

WILL'. LEACH 'TAYLOR'S BILL FOR HIS GRACE FROM CHRISTMAS TO LADY DAY， 1726. 241011 .

$1725 \mathrm{Dec}^{\mathrm{r}} \cdot 27^{\text {th }}$. $£$ s. $d$.

For making a Hunting Coat and Veft $\quad \ldots \quad 00 \quad 16 \quad 00$ for $1 \frac{1}{2}$ yard fine Scarlet at $16 s . \quad \ldots \quad \ldots \quad \ldots \quad 010400$

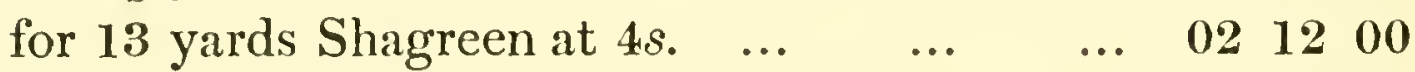
for silk Buchram Canvas and 'Twift ... $\quad \ldots \quad \ldots 000500$ for 1 doz. and 3 Silver plate Coat buttons at $16 s$. $0100 \quad 00$ for 3 doz. and 1 Breaft Buttons at 10s. $\quad \ldots .01 \quad 1010$ $1726 \mathrm{Jan}^{\text {ry }} \cdot 25^{\text {th }}$.

For 2 pair Large silk Garters, at 3s. $6 d$. $\quad \ldots \quad 000700$ Feb. $4^{\text {th }}$.

For papering a blue velvet sute $\quad \ldots \quad \ldots \quad \ldots 000206$ March $1^{\text {st }}$.

For making a Sute with Silver Loops both sides of $\mathrm{y}^{\mathrm{e}}$ Coat \& veft bound $\left.\quad \ldots \quad \ldots\right\} 020500$ for $7 \frac{1}{2}$ yards Cherry Color'd Italian Mantua to

Line the Coat at $8 s . . . \quad \ldots \quad \ldots \quad \ldots$ $0300 \quad 00$ for 9 yards Shagreen to line $\mathrm{y}^{\mathrm{e}}$ veft \& breeches

at 4 s. \} $01 \quad 1600$

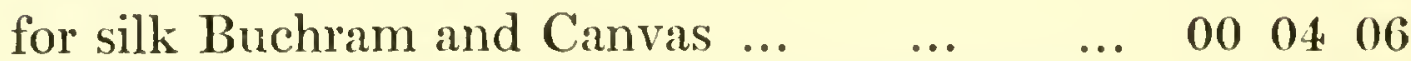
for 3 doz. and 4 Silver wyre Coat buttons at 13s. 020304

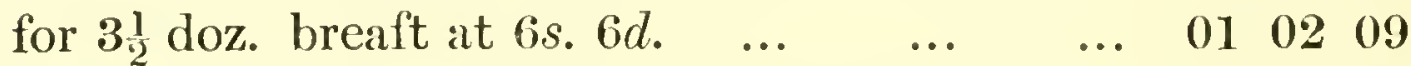
for $\frac{1}{2}$ Ounce silver ' $T$ wift to $\mathrm{y}^{\mathrm{e}}$ breeches $\quad \ldots \quad 00 \quad 0400$

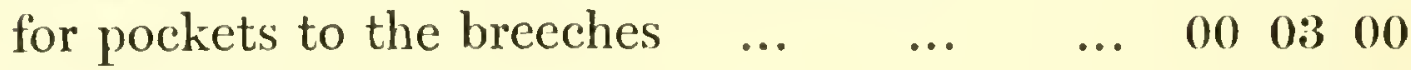

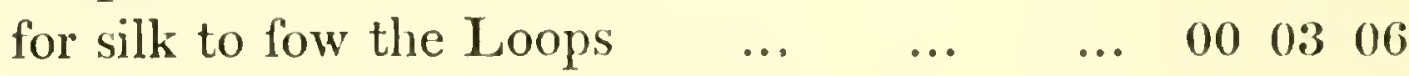




\section{Records of the Old Charlton Hunt}

for flannel to Interline the body of the waftcoat $\begin{array}{cccc} & £ & s . & d . \\ 00 & 03 & 06\end{array}$

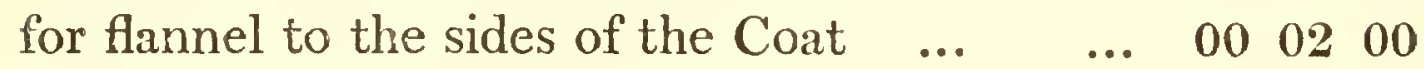
for a pair large Silver Garters ... $\quad \ldots \quad \ldots \quad \ldots 000806$ $\left.\begin{array}{ccccccc}\text { for mending a } & p^{\Gamma} \text {. } & \text { Buckfkin } & \text { breeches } & \& \\ \text { Mantua silk } & . . & \ldots & \ldots & \ldots & \ldots\end{array}\right\} 00 \quad 0206$ for mending a Buff veft and new lining the

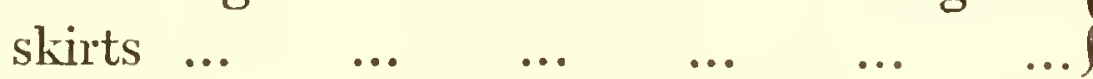
000200 for 1 yard shagreen to line the skirts ... $\quad \ldots .000400$ $13^{\text {th }}$.

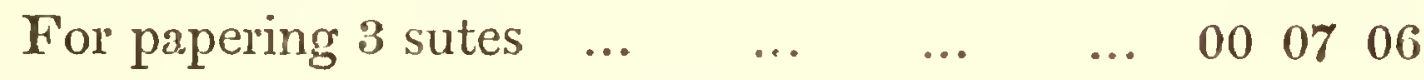
$23^{\mathrm{d}}$.

For making a $\mathrm{p}^{\mathrm{r}}$. Velvet breeches $\quad \ldots \quad \ldots \quad \ldots 000400$

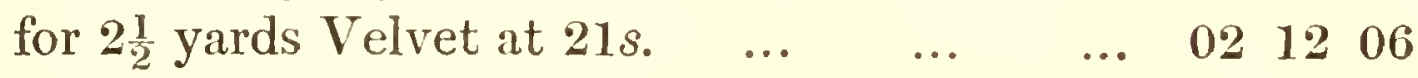

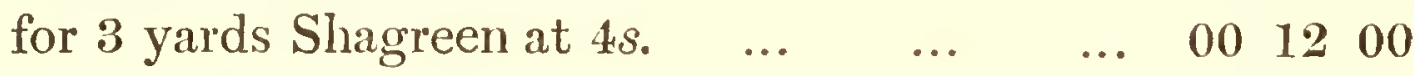

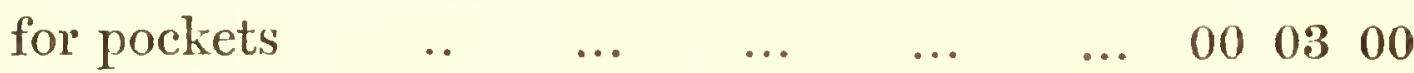

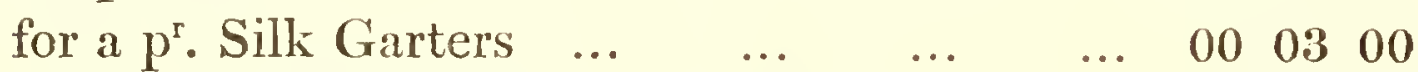
for Silk Canvas Buckram and Buttons $\quad \ldots 000300$ ffor Button \& Loop to a dark padofse Coat ... 00010106

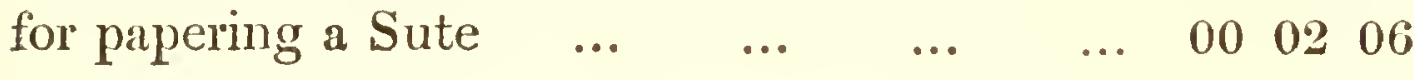




\section{Records of the Old Charlton Hunt}

\section{A RECEIP'TED BILL OF JOHN WARE, WHOM 'TOM JOHNSON SUCCEEDED AS HUN'TSMAN}

['The spelling is almost unique.

I imagine "paid for 2 Shows a honting" must mean "shoes." And "a pare of bouts" at $12 s$. strikes one as being very reasonable, as also does the $5 s$. disbursed for a fortnight's lodging at Findon!!]

\section{Noumbr $\mathrm{x}^{\mathrm{r}} 201730$ his grace the Duk oF RICHMIOND BILI.}

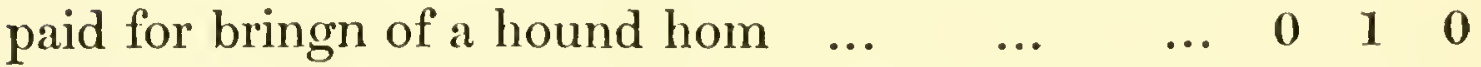

$\begin{array}{llllllll}\text { paid for } 2 \text { Shows a honting } & \ldots & \ldots & \ldots & 0 & 1 & 0\end{array}$

$\begin{array}{lllllllll}\text { paid for whipcord } & \ldots & \ldots & \ldots & \ldots & \ldots & 0 & 2 & 6\end{array}$

$\begin{array}{lllllllll}\text { paid for ritng paper } & \ldots & \ldots & \ldots & \ldots & 0 & 1 & 0\end{array}$

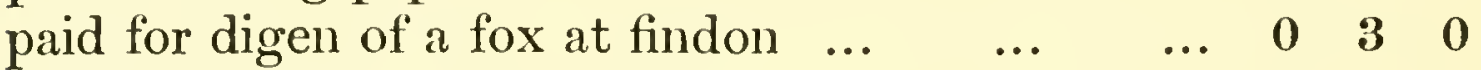

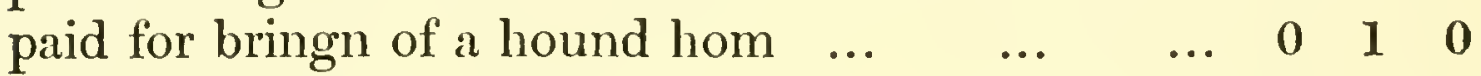

$\begin{array}{llllllll}\text { paid for bringn of a teryor hom } & \ldots & \ldots & \ldots & 0 & 1 & 6\end{array}$

$\begin{array}{llllllll}\text { paid for } 2 \text { Shows a honting } & \ldots & \ldots & \ldots & 0 & 1 & 0\end{array}$

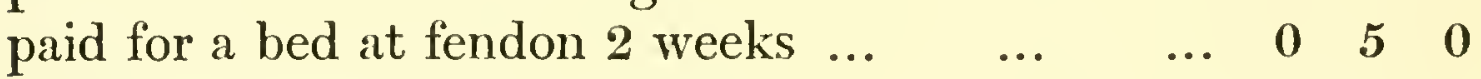

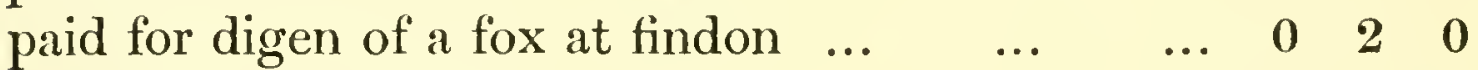

$\begin{array}{llllllll}\text { paid the smithes bill at findon } & \ldots & \ldots & \ldots & 0 & 6 & 0\end{array}$

$\begin{array}{llllllll}\text { paid for a hors hire } \ldots & \ldots & \ldots & \ldots & \ldots & 0 & 1 & 6\end{array}$

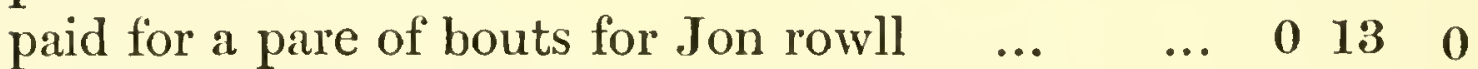

paid for a pare of bouts for Richard taylor $\quad \begin{array}{llllll} & \ldots & 0 & 12 & 0\end{array}$

To $23 \mathrm{No}^{\text {ber }} 1730$

2116

Goodwood the $23^{\text {th }}$ of $\mathrm{No}^{\text {ber }} 1730$ Recvd there of His Grace the Duke of Richmond by the Hand of Sat. Labbe two pounds Eleven shillings \& Sixpence in full of this Bill I say Recrd by me

JOHN WARF. 


\section{CHAPTER IX}

\section{EARL TANKERVILLE'S INSTRUCTIONS \\ Dated Christmas, 1746.}

The Golden Rules and Etiquette of the Sport of Kings have never been better set forth than in the following :-

The Hounds not to be kept behind the Huntsman in the Morning to whatever Country they go, except at times when they are oblidg'd to go through Corers.

The Whippers-in to be forward, and if any Hound, or more happens to prole from the Roade they goe, to call on them, but to use no whip, for if they know their Names at Home, they'll obey abroad.

When you are come to your Beat the Huntsman only to Speak to the Hounds, and the lefs the better.

The Whippers-in to have a good look out stop any Hounds that Steales away with a Scent, and leares the Body of the Pack behind, unlefs tis a good one, and has time to give notice for the rest to be well laid in.

The Whippers-in not to to speak by way of incouraging any Hounds in Cover, but in case of Riot, then they shall gently rate them off.

Afsoon as they have found, one Whipper-in to go with the Huntsman, the other to stay behind, to bring any 


\section{Records of the Old Charlton Hunt}

stragling or tale Hound, or Hounds, that may be left behind, which will seldom happen if the two Boys knows their Buisnefs, \& dos their Duty.

Tis not a part of the Buisnefs of a Whipper-in at any time to Speak to a Hound, otherwise then keeping them together, or rate into the Huntsmen, who shu'd always be with the Main Boddy of the Hounds.

Nither Huntsman, or Boys, to Speake to the Hounds, while running with a good Scent. On a midleing one the Huntsman to incourage his Hounds at discretion, without any other persons interfereing.

The Company always at a Distance that the Hounds may not be hurryed, which is the lofs of many a Fox, as well as the lofs of a great deal of Beauty a good Pack of Hounds will shew at a Half Scent.

When the Hounds from running comes to a Check, the Huntsman is not to Speak, but allow the Hounds to have their first Cast, and if after that, not hit off, the Huntsman to observe the point at which they threw up, and then to help the Hounds to the best of his Judgement, but without hurry, for when a Fox is Sinking, time must be taken, as he then runs short, and is often left behind by Clapping Down.

The Gentlemen for their own Sakes will Observe that a Confabulation down the Wind often heads a Fox and indangers the whole days Sport. 



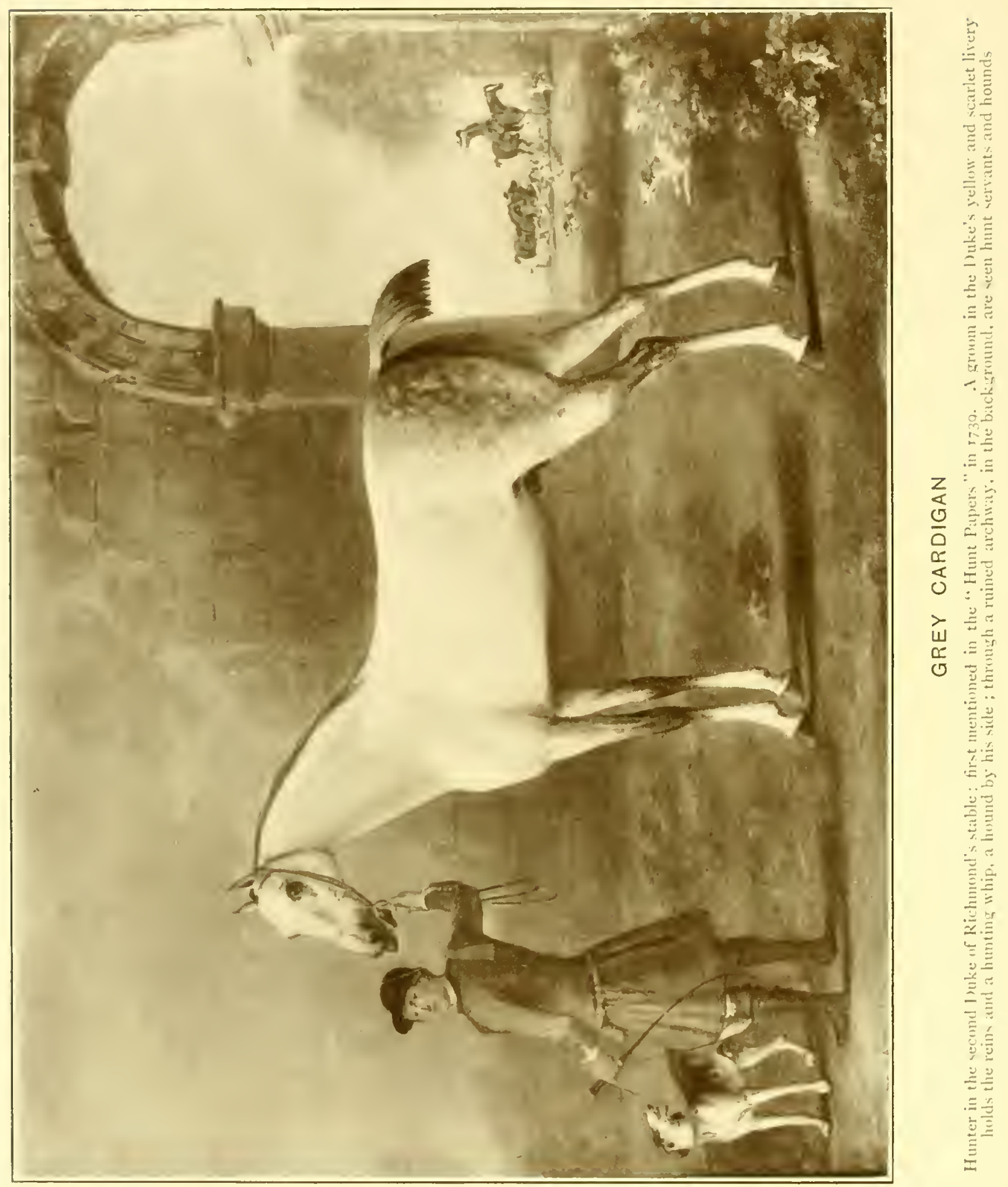




\section{CHAPTER X}

\section{LETTERS FROM BROTHER SPORTSMEN}

From the Duke of Bolton,* at Charlton, to the Duke of Richmond, in London.

\section{Mr Lori}

Dec. 6, 1727 .

I had the honour of your Grace's Letter, \& as to the diserter's being 'Try'd I beleive as you doe $\mathrm{y}^{\mathrm{t}}$ it is time enough. The power for holding a Gen ${ }^{11}$. Court Martial is Lock'd up in my Closett att London, soe $\mathrm{y}^{\mathrm{t}} \mathrm{I}$ can't refer to $\mathrm{y}^{\mathrm{t}}$ till I come to town, butt I beg you will be soe good to gett wone from the Warr Office, or a Copy of it, \& bring it down $w^{\text {th }}$ you, \& $y^{\text {n }} \mathrm{I}$ will send order's for $\mathrm{y}^{\mathrm{e}}$ Tryall, I beleive any Thirten Comifsion Officer's may Compofse $y^{\mathrm{e}}$ Court Martial, butt $\mathrm{y}^{\mathrm{t}}$ you may easily know, as to our sport wee had very good last Fryday, wee went outt on Monday butt were driven home by the Rain, soe wee hunted yesterday $\&$ kill'd a fox $\mathrm{y}^{\mathrm{t}}$ gave us soe Little Runing, $\mathrm{y}^{\mathrm{t}}$ wee intend to hunt to day if the frost will lett us ; I hope you won't alter' your Resolution of coming, it is much desir'd by the whole Company, butt most ardently by $\mathrm{y}^{\ominus}$ old $\mathrm{Gen}^{11} \cdot \uparrow$ who toast's you every day, Honywood is a Little pleas'd att the

* The Duke of Bolton was Master of the Charlton Hunt from 1723 to 1728. The reference to Court-martial is obscure.

$\dagger$ "Ye old Generall" is General Honywood, an original member of tho Chariton Hunt. 


\section{Records of the Old Charlton Hunt}

oposition to your List, \& wee all conclude $y^{t}$ Delawar stay's for $\mathrm{y}^{t} \&$ some more weighty affaire, the Company desire's there service to your Grace, \& I beg you'l believe me

\section{My Dear Lord \\ Your Grace's most faithfull \\ \& Obedient Humble Srvt.}

BOLTON.

From Mr. Charllon, at Charlton, to the Duke of Richmond, in London.

Mr LORD,

Nov, 26, 1731 .

The Hounds came hither on Satterday last having bin purg'd that weeke at Findon before they came away, $\&$ Jack $W$ are expecting to find yo $^{r}$ Grace here did not write you an account of it. Wee hunted on Monday at Burton where wee fell in with a litter of Foxes \& our hounds divided. One parcell went over the River \& run a fox to ground about three miles, \& $y^{\mathrm{e}}$ other rum a fox to ground at Red Hill nêar Burton park, wee afterwards run from Fox to Fox till wee were forc't to take of, On 'Tuesday wee earry'd the Young Hounds to Old Park by the sea side where after rumning an hour or two they kill'd a Fox, On Wednesday wee went with the old \& young Hounds together to Farme Wood where wee found a fox who came away all the good Country through the 'Teagles \& was going for Eastden Wood but $\mathrm{M}^{\mathrm{r}}$. Ormes being out a shooting there headed him \& put us to a fault but wee hitt it of \& run him back the side hills to North comb, where he got 


\section{Records of the Old Charlton Hunt}

into the Earth, Had he not bin headed wee had surely kill'd him, wee afterwards went down to Burton \& found a Brace of Foxes \& the Hounds divideing one part come up the Hill \& the other to Bignall park but it being late \& the weather bad wee were forced to take of \& made it dark night before wee cane home, The Hounds are very well (except a few lame ones) \& seem to be verry steady both the young as well as the old, \&, if wee had but some rain I am confident they will show yo $^{\mathrm{r}}$ Grace verry good sport, but without that the Ground is so dry it's allmost impofsible on the Hills to do any thing \& now wee have a hard frost that has prevented our hunting to day as I fear it will do to morrow, $\mathrm{Yo}^{\mathrm{r}}$ Horfes here are verry well \& you have three of $\mathbf{M}^{\mathrm{r}}$. Orme's, which Jack Ware rides sometimes, I hope thô the Frost continues wee shall have the pleasure of seeing you here after the Masquarade is over, Mr. Honywood is much yo ${ }^{\mathrm{r}}$ Grace's hum ${ }^{\text {ble }}$ Serv $^{\mathrm{t}}$. as well as

\section{A. Charlton.}

All the Wells here are quite dry \& wee are forc'd to send to Cocking * for water.

From Mr. Charlton, at Charlton, to the Duke of Richmond, in London.

Mr LoRD,

Dec. 3, 1731 .

Wee were yesterday at the Ruell \& the minute wee came fell in with a litter of Foxes, wee were a good while before wee cou'd stick to one, at last wee did \& was verry

* Three miles away! 


\section{Records of the Old Charlton Hunt}

near killing him, \& unlefs he got into some hole, I can't imagin how wee lost him, this being in the Ruell is the occation of my writeing to $\mathrm{yo}^{\mathrm{r}}$ Grace to desire you to speak to the D. of Norfolk about the ways in the upper part of the wood to be cut, for they grown up so there is no rideing, And as $\mathrm{M}^{\mathrm{r}}$. Jbitson his old Steward is put of, a new one won't do any thing without his Grace's orders, as I beleive there is a good many Foxes there wee shall visit that cover often, the sooner therefore wee can get the ways cut the better, Wee were on Monday at Old Park \& run a Fox two or three hours but cou'd not kill him, Now there is a prospect of the weather altering for the better I am in great hopes of seeing some good sport, for yesterday I thought the Hounds perform'd (considering the weather) as well as cou'd be desir'd; \& I likewise hope soon to see your Grace here to be try'd, judg'd, (but I hope not condemn'd) for drawing your forces too near a neighbouring Prince's Front Your Horfses came hither yesterday, Bay Bolton continues lame, \& Friend John ran away with the Boy into a bush \& has hurt his Eye so much that the Groom fear's he will loose it, the rest are all well ; I am

Yo $^{\mathrm{r}}$ Grace's most faithfull

\& obedient hum ${ }^{\text {ble }}$ Serv'.

A. Cimariton. 


\section{Records of the Old Charlton Hunt}

1832.

From Lord Delawarr, Bolderwood, to the Duke of Richmond, in London.

[Jack Ware in disgrace.]

My LoRD,

Oct. 2, 1732 .

I came hither last night, and have this morning viewd your Graces Hounds very carefully, and can assure you there is either very much ignorance, or Neglect, in the Composition of Jack Ware, nor Do I think Rowell quite to be excus'd. I seperated from amongst the Old Hounds eight Couple throughly Mangey, they say they have anointed them and given them some Ethiops Mineralis. So I immediately purg'd them and with the Buckthorn gave them some Flower of Sulphur, both to take off the Griping quality of the Buckthorn, and so throw the Humour out of their Blood. When I went from Hence I thought such an Accident impossible to have happen'd, for they were very clean, and since that have had seren times Whey, and each time 2 pound of Brimstone, which course of Physick would have cured the great Devil of the Mangs, and now these have it, but I hope to sett them to rights; This was the Manner that made him bring in Such Apothecarys Bills, and to be sure att this rate they will want more Physick than Meat. With the remaining part of the old ones We shall Hunt to morrow, the Ground is

* John, 1st Earl Delawarr, assisted the Duke in the management of his hounds for many year's.

He found Jack Ware a great trial, and was greatly relieved when Tom Johnson succeeded as huntsman.

Bolderwood was the Duke's headquarters in the New Forest.

113 


\section{Records of the Old Charlton Hunt}

soft enough, but if there does not come rain I will not go out again.

The Young Hounds are still kept apart, neither have they endeavourd to enter any of them, this Peice of Lasiness, may be lucky, for one of them call'd Ruler bred by $\mathrm{M}^{\mathrm{r}}$. Ormes, did not care to feed last Friday, he was immediately taken from the rest and lock'd up, he pin'd away, and I had him dispatch'd this Morning. He never offered to bite as they say, so that It may be any thing else as well as Madness, however this cannot affect your Old Pack, they never having kept company togather: Neither do I think it possible that Madness can without shewing it self, be 19 weeks in any Dog (for so long it was last Friday) since any Hound has been mad. This I beg you to talk to some of Your Surgeons, Physitians, and Philosophers, and send me their Opinion. Your Horses are very well and in fine Order. I shall say no more att present on this Subject, but assure you I will do my utmost to sett things to rights, only if Lovell would recommend two or three couple of truly good Hounds to you, I should not be against your Buying them for I do not think three or 4 of the Young ones will do. This is the present state of the case. When will you have them go to Findon.

I orderd Whenever my Panicr de Gibier comes from France to have it carried directly to your Grace if it is well stockt, pray spare my Mother a Brace. I desire my Lady Dutchess to accept of my sincere respects, and that you will beleive me My Dear Lord Duke Your Graces

Most faithfull and

Obedient Servant

DeLawarir. 


\title{
Records of the Old Charlton Hunt
}

\author{
From Lord Delawarr, in the New Forest, to the Duke \\ of Richmond, probably at Gondwood.
}

Saturday, Oct. 7, 1732.

I had this Morning the favour of your Graces Letter, with one inclosed for Jack Ware * He was so ashamed of the Condition the Hounds were in, and does obey directions, so willingly, when I am with him, and I think does to the best of his Capacity, that I own I cannot have the Heart to give him such a Mercurial, I truly think it more for your Graces Service Not to depress his Spirits, with a Severe reprimand for the fault he is so Sensible of. The Hounds have done so well with their Physick given in that manner that I do not doubt but to bring them as fine as Lap dogs into Sussex.

My Last gave you an account of our Sport on Tuesday last, We went out on 'Thursday, but when we were gone A Mile, found A Violent storm of rain coming on, so return'd and put up the Hounds. Yesterday we went out with all the Old Hounds, and 2 Couple of Young, we took a Drag, and Hunted to him, it was not a Scenting Day, but we still kept it moving, till we got near him, he would have got into A Coney borough, but he chose so small a one that the Hounds pulled him out without the Help of any Instruments, it was just such a Days work as I could have desired after their Physick, for the whole was over in two hours, without any rain, and I brought them Home and fed them att their usuall time, so that I do not doubt but they will

* Jack Ware was a most indifferent huntsman, and was superscded by Tom Johnson the following year. 


\section{Records of the Old Charlton Hunt}

be in rare trim on Monday. I take very particular Care not to lett the Young Hounds come into the Same Kennel with the Old nor feed with them. 'The Pack is likely to be well in Blood, and to know an Earth, which is what I think very lucky for they us'd frequently to leave A Fox att Ground and never lay att the Earth, I hope we are very secure from that att Present.

Old Driver * died yesterday att three o'Clock; When we lett the Hounds out on 'Thursday, he went very lame in his shoulders, so I had him put back, and put by himself, he fed as well as any Hound could do on Wednesday; I gave him Milk, and other Meat, when he was put up, he lap'd the Milk, and eat his meat, and when I came home from Hunting Yesterday I saw him my self, eat his Meat att 12 of the Clock, and he died att 3 as I said before. I sent for Harry Woods, and every body agrees it is not madness, for he Swelld very much, he did not Slaver, nor howl, neither would he have Chew'd his meat, three hours before he died had it been Madness, he was twelve years old and no body thought he could have lasted this whole season.

I am very glad to hear, Your Grace mends so fast, and hope to Meet you in Sussex, I do propose being with the Hounds att Charlton the $20^{\text {th }}$, att farthest, if this Country should be too wett, I will move them sooner, for I assure you I shall have no Consideration, in being here longer than is for the Benefitt of your Hounds, for I make no question of perswading my Wife, to go to London.

Jack Ware told me yesterday (but I hope he is mistaken) that the Copper att Charlton belongs to

" "Driver" was 8 years old, and was by Charlton "Bell" out of the I) 


\section{Records of the Old Charlton Hunt}

Tankerville: if so has he not taken it away? that is to be look'd after, for we shall make a bad figure to come and have nothing to boyl our Meat in for the Hounds. Pray remember the Stables and Kennel att Findon.

By your Mentioning Misaubin, I suppose there is a Happy reconciliation, of which I give your Grace Joy, as I shall of every thing that can any ways contribute to your Diversion being very truly my Dear Duke

\section{Your Most faithfull \\ \& Obedient Servant \\ DeLawarr.}

I am Lady Dutches's most obedient, pray remember me to my fellow traveller 'Tom Hill.*

From Lord Delawarr to the Duke of Richmond, probably in London.

[On the subject of an unsatisfactory state of things at Findon.]

Nov. $4,1732$.

I am sorry to find by your Graces Letter which I received this Day that you have not received mine which I writ this Day sevennight, it was full of my reflexions upon the present state of Affairs att Finden. $\mathbf{S}^{\mathbf{r}}$ Rob $^{\mathrm{t}}$ Faggs Brutality is what made me so very dilatory in my coming

* Tom Hill began as Tutor to the Duke when Lord March, and remained with him for many years as a Private Secretary. 


\section{Records of the Old Charlton Hunt}

down, for I thought it would be but a Dismall Life to sett these long Nights by my self, and to Hunt with the Earths unstop'd. $\mathbf{S}^{\mathbf{r}}$ Rob $^{t}$ may say what he pleases, but it is to shew his ill Humour to $\mathbf{S}^{\mathbf{r}}$ Cecyl in particular, and to the rest of the world besides, for nothing can be more rediculous than to say that $\mathrm{He}$ will lett them be stopt when Gentlemen are there, but for the interim he will contrive to have the Hounds kept so much from Blood that they will not be able to shew sport to any one that does come.

I have had but one Letter from Jack Ware since they have been there, so God knows what they do.

$\mathbf{M}^{\mathrm{r}}$ Charlton and $\mathbf{I}$ intend to be down before the Time for moving the Hounds, so that I will march my Forces back to their Head Quarters. The Weather has been excessively cold these ten Days so that I fear they have not done much. I desire my humble Service to Lady Dutchess and that you will beleive me My Dear Duke

\section{Your Graces}

Most Faithfull \&

Obedient Servant

DeLawarr.

I have this Day an India Sow from Bengal with Pig, would you have me save you one they say they are excellent good meat. 


\section{Records of the Old Charlton Hunt}

From Lord Delawarr to the Duke of Richmond, at Charlton, in reply to a complaint of the latter as to the bad condition of horses and hounds when they arrived at Charlton from Findon.

Nov. $30,1732$.

My Lord.

This is to acknowledge the favour of both your Graces Letters, and I cannot but be very much concern'd to find by the first of them, as well as by $\mathrm{M}^{\mathrm{r}}$. Charltons, that the Hounds are so very low. The Secret of that is hard to unravell, unless you will think, that John Rowell is old and Lazy and will not feed as he can; and that the other is young and ignorant how to do it. As to what he alledges that they have not flesh enough it may certainly be answerd, why have they not, who hinders it. They have not been controul'd these five weeks that I know of, unless it is a Greivance to have an account kept of what Oatmeal is deliverd to them every week, but the quantity is not limited, so that they have taken what they would, only what they have taken is known, And you may See by the Account of the Horseflesh which you have by you, that was used in the Forest, that they were not Sparing, and how their Modesty comes to make them err on the other Side, can proceed from nothing but their not paying those Bills themselves. If the Servants will not cooperate it is impossible for any mortal to have a Pack of Hounds in Order. I own I rather think they seem by the accounts I have received that they take Pains the other way, for 


\section{Records of the Old Charlton Hunt}

without Skill any Dog will be fat that is not workd hard which is their Case. Unless you will allow that the quantity of Medicines they have taken have quite torn their constitution to Peices. As to the Poor work they made of the Mondays Chase, that I beleive may partly proceed from there having been no rain since the Frost, and in that case I never saw the Scent lay, for the Grounds allways carry.

As to you Graces $2^{\text {d }}$ Letter which I receiv'd this Day, I am sorry any Horses were purg'd without your knowledge, and much more so that any should want it besides the two $\mathrm{y}^{\mathrm{t}}$ are now purging, which I told you att Godalmin were to be purgd att Findon, but I suppose the Distemper they had there prevented it. I fancy that may have put them out of Condition. For they were all purg'd before they left Bolderwood, and came as clean and as well from thence as any Horses in the World, as you saw, if you calld att Charlton as your Grace told me you would. John Bud* said he never saw the Horses come in such order for riding in his Life. I have been very impatient to wait on your Grace in Sussex, and I shall come very soon for I only stay to sign some writing as Lord Cowpers 'Trustee and then shall wait on you. I am, My Dear Lord,

\section{Your Graces}

Most Faithfull and

Obedient Servant

DeLawalir.

My most humble Service to her Grace.

* The author of the 'Sussex Garland.' 


\section{Records of the Old Charlton Hunt}

As to their being sick with Antimony, it is a Cursed Lye, for they both know they fed well with it, and after it. if you give a Pound amongst the Pack, it will both Vomit and Purge them, $\mathrm{w}^{\text {ch }}$ in some cases is necessary, but 3 or 4 ounces mixt with a pound and half or two pound of Brimstone, will only open them, if it is mixt as it ought with the meat and not given in Lumps. but why always Physick?

From Lord Delawarr, in London, to the Duke of Richmond, at Goodwood. A reply to various questions.

[The "insertion" mentioned is unprintable!]

May $31,1733$.

I had the favour of your Graces Letter, by the last Post, And am glad so many [ ] Foxes got safe to Sussex Eleven set out of Town, so one I perceive was lost or died on the Road. As to the Register book of the Hounds it is in the New Forest, I never trust it from the Place where they are, so cannot have it copyd till I go into the Forest, and then will not fail to have it done according to your Desire.

As to the Queries you propose to me I shall answer them as well as I can. Her Royal Highnefs* will not be dépucellée till August as it is thought. 'The Parliam ${ }^{t}$

* The Princess Royal. She married the Prince of Orange in Maroh 1734. 


\section{Records of the Old Charlton Hunt}

will probably rise in ten or twelve days. Lovel is not certain of the Gold Staff. Lord Onslow goes as he did, and so shall $\mathrm{I}$ in professing as I truly am

$$
\begin{aligned}
& \text { My Lord } \\
& \text { Yr Graces }^{\mathbf{r}} \text { Most Humble \& } \\
& \text { Obedient Serv } \\
& \text { DeLawarr. }
\end{aligned}
$$

The Duke of Montagu you may perceive is in good health by the insertion he has made in this Letter. Lovel is also here.

$$
\text { past } 10 \text { at night. }
$$

From Lord Delawarr, in London, to the Duke of Richmond, probably at Goodwood.

[Mostly about the Opera.]

June 16, 1733.

I hope that the Dutchess is now so well recover'd that this Letter will not be inconvenient to your Grace, I can truly assure you I was sensibly touchd when I heard how very ill her Grace was, and do most heartily congratulate you on her recovery. The last Letters from the Forest give a very good account of your Hounds and Horscs. I have 3 Foxes att present in the House. Give 


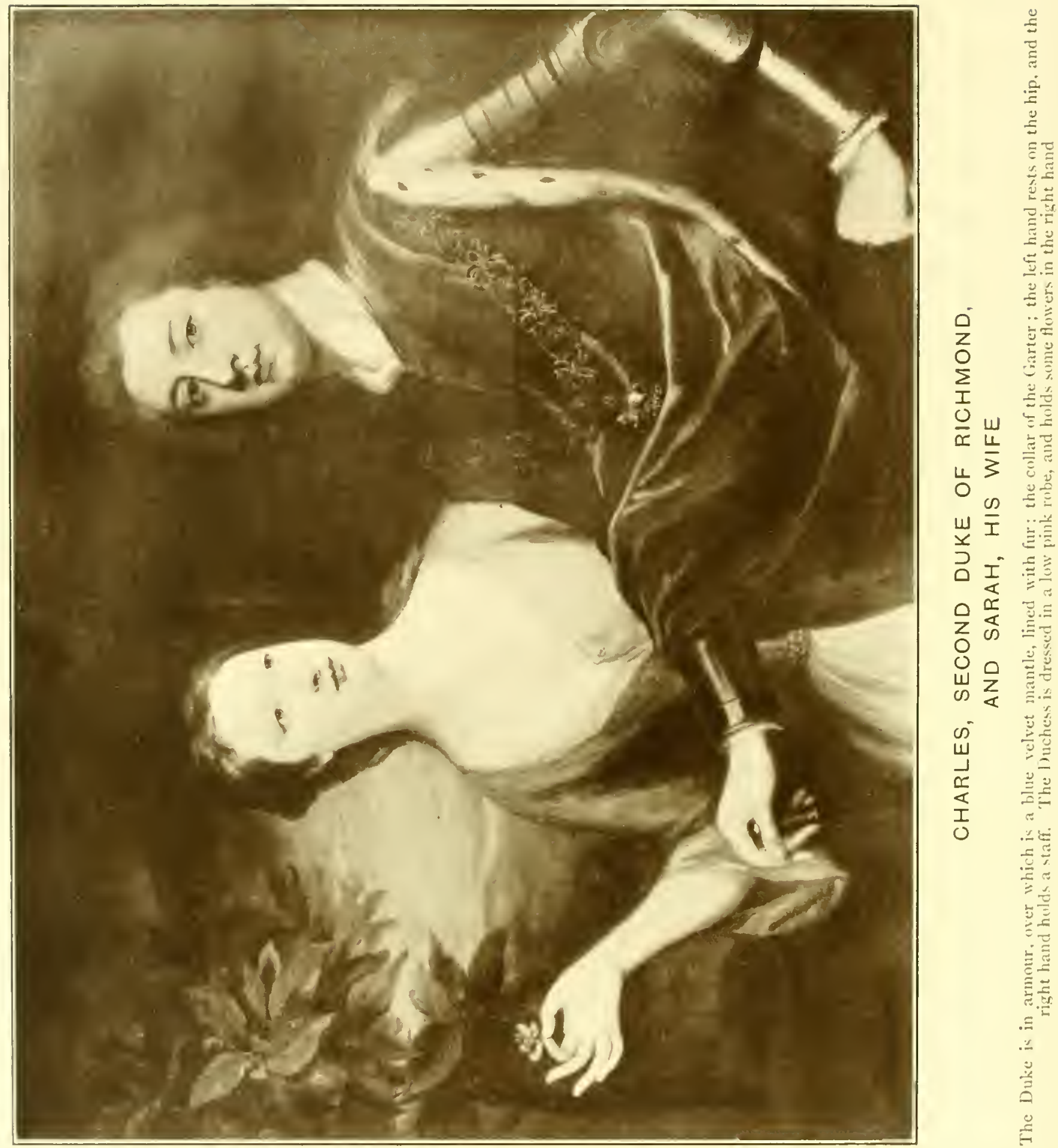


\section{Records of the Old Charlton Hunt}

me leave to advise you not to have many att the same time in the Pen for they will dye with the Stench, and for want of Liberty.

As to Politick News you have certainly heard all I can possibly say, by other hands, Except that Lovel in a Day or two is to have his Wishes; but what; he will not reveal, at least to me, as soon as I know, I will not fail to acquaint you with it.

There is a Spirit got up againt the Dominion of $\mathrm{MI}^{\mathrm{r}}$. Handel, a subscription carry'd on, and Directors chosen, who have contracted with Senisino, and have sent for Cuzzoni, and Farrinelli, it is hoped he will come as soon as the Carneval of Venice is over, if not sooner. 'The General Court gave power to contract with any Singer Except Strada, so that it is Thought Handel must fling up, which the Poor Count will not be sorry for, There being no one but what declares as much for him, as against the Other, so that we have a Chance of Seeing Operas once more on a good foot. Porpora is also sent for. We doubt not but we shall have your Graces Name in our Subscription List.* The Direct ${ }^{\mathrm{rs}}$. chosen are as follows. D. of Bedford, $\mathrm{I}^{\mathrm{ds}}$. Bathhurst, Burlington, Cowper, Limmerick, Stair, Lovel, Cadogan, DeLawarr, \& D. of Rutland, Sr. John Buckworth, Henry Furnese Esq., S ${ }^{r}$. Micl. Newton; There seems great Unanimity, and Resolution to carry on the Undertaking comme il faut. I propose to set out for $M^{r}$. Brights the latter End of Next Week. Various are the Reports about the D. of Montagu, some say the Gentlemen Pensioners, some the Governm ${ }^{t}$. of the Isle of

* The Duke was a prominent patron of the Opera and formed one of the Syndicate whose names occur in the next paragraph. 


\title{
Records of the Old Charlton Hunt
}

Wight. I can muster no more News so shall trouble you no more than to assure you I am with the greatest truth My Dear Lord Duke

\author{
Your Graces
}

Most Humble and

Obedient Servant

DeLawarr.

From Lord Delawarr, Bolderwood, to the Duke of Richmond, Goodwood.

[About a horse, and other items connected with the Hunt.]

My LonD.

July 14, 1733 .

I have this Day, with $\mathbf{M}^{\mathrm{r}}$. Andrew, and Roger Williams survey'd the Horse, and we do unanimously agree that he is A very genteel Horse and sound; but we do not think him fit to carry more than twelve or thirteen Stone att most, His Body being lengthy, and we are apprehensive he will be A thin Carcass'd one when Drawn. So that unless you send your positive Commands to the Man he is not to come to you.

I expected my Groom this Day from Mr. Brights, but he is not yet come. The King goes on Monday to Hampton Court, So I hope to wait on you soon but believe I shall take you in my return from the Forest and then I 


\section{Records of the Old Charlton Hunt}

can report to you how affairs are. The Brass Horns * went last week and the Maitre de Musique sets out on Monday. My most Humble Service to her Grace from My Dear Lord Duke

\section{Your Graces}

Most Faithfull \&

Obedient Servant

Delawarr.

From Lord Delawarr, Bolderwood, to the Duke of Richmond, Goodwood.

[Complaining of the bad state into which the Hounds have been allowed to get by Jack Ware.]

My LoRD.

Aug. 11, 1733.

I have been here A Week, and am sorry to tell you I found a great number of your hounds very much tainted, and not the old ones only, but some of the most hardy, as Tapster, $\uparrow$ Kindness, \&c. And I am much afraid it will break out still more in the Pack. I find they have been fed as high and with as much flesh this Hot Summer when they have not stirr'd as in the Winter, when they Hunt; It is easy to imagine the Consequence. I have now lowerd their Diet, and they are in a Course of Physick, not but they have been very lavish of it, but without knowing how to give it.

* The Huntsman, and probably one or two others as well, carried the large circular French horn which will be seen in the illustration of "Grey Cardigan."

$\uparrow$ Sec illustration at page 47. 


\section{Records of the Old Charlton Hunt}

I am obliged to go to Hampton Court Next Wednesday so what commands you have for me I shall receive there, and I propose to come hither again soon after the Installation, and I doubt not but to get the handsomest Pack I ever saw, In order against you do Bolderwood the Honour of a Visit. I have much to talk over with you, But I have so far Ventured as to tell John Rowell that it is expected from him that the Hounds are in good order, as to their Health. He said then they shall if I may.* I told him I depended he would, and it was expected from him. I shall wait on your Grace soon att Goodwood if I do not see you att any of the Ceremonies before the Wedding. $\dagger$ Your Horses are perfectly well and fine. The Boys will Blow the Brass Horn well, but Jack ware is as forward in $\mathbf{3}$ weeks as one of the Boys was in two days as their Master says, It was his desire to Learn, and not put upon him. My Humble Service to her Grace I am My Dear Lord Duke

\section{Your Most Faithfull \\ $\&$ Obedient Servant \\ Delawarr.}

* This reply was not so ambiguous as it now seems. May was then still used in its original sense of can.

$\dagger$ Probably the wedding of the Princess Royal, which had to be postponed until the following year on account of the illness of the Prince of Orange. 


\section{Records of the Old Charlton Hunt}

From Lord Delawarr, at Hampton Court, to the Duke of Richmond, probably at Goodwood.

[A caution against overstocking.]

My LoRD

Aug. 20, 1733.

I have Sent your Grace an exact List of your Pack, and of the Puppys, by it you will perceive that you are strong, and I fear will in another Year be overstock'd if you breed so many. [But you are now to Consider which Bitches you would have spaird; I know no benefit that will accrue by them unless it is more Hounds to be given to the Huntsman.] I am sure 5 or 6 Bitches will breed as many Hounds as any body can want. I am in great Hopes You will do me the Honour to Come to Bolderwood next Month, and I should be glad to know what time you would like, for I then would contrive to make that my time for the Forest.

I calld att Hackwood, and the Duke of Bolton, bid me let you know you may have the Hunter he recommended to you, but his price is 150 Guineas. That is a great Price so you should be well satisfied about him. I saw him he is a fine strong Horse but I did not see him move. My Compliments to Lady Dutchess, and believe me

Your Faithfull \&

Obedient Servant

Delawarr. 


\section{Records of the Old Charlton Hunt}

\section{LIST OF PUPPYS, 1733}

\begin{tabular}{|c|c|c|c|}
\hline Pymont & $\cdots)$ & George Etheredges & \multirow{4}{*}{ Crimson \& Cocker. } \\
\hline Crowner & ... & 'Thomas Brent & \\
\hline Curious & $\ldots$ & Farmer Savin & \\
\hline $\begin{array}{l}3 \text { att Goc } \\
\text { wood }\end{array}$ & & & \\
\hline Sherewood & $\ldots$ & Richard Etheredge & \multirow{3}{*}{ Careless \& Cocker. } \\
\hline Conqueror & $\ldots\}$ & Charles Earleys .. & \\
\hline Smerkin & ... & John Plot ... & \\
\hline Blewman & $\cdots$ & John Young & $\begin{array}{l}\text { Kindness \& } \mathrm{L}^{\mathrm{d}} \text {. } \\
\text { Tank }^{11 \mathrm{~s}} \text { Blewman. }\end{array}$ \\
\hline Darling & ... & George Snouks & $\begin{array}{c}\text { Venus \& D. of } \mathbf{S}^{\mathrm{t}} \text {. } \\
\text { Alban's Redcap. }\end{array}$ \\
\hline Jumper & $\cdots)$ & Ralph Street & \multirow{4}{*}{ Dido \& Jumper. } \\
\hline Jugler & ... & Peter Dove & \\
\hline Jupiter $\}$ & & Farmer Linningtor & \\
\hline $\begin{array}{l}\text { Juno } \\
\text { Judith }\end{array}$ & & Haywood Mill & \\
\hline Emperor & $\ldots)$ & Edward Wild & \multirow{4}{*}{ Virgin \& Jockey. } \\
\hline Dashwood & $\because$ & $\mathrm{W}^{\mathrm{m}}$. Wings & \\
\hline Bonny & $\cdots$ & Peter Bailys & \\
\hline Lovely & $\ldots$ & Alice Maizey & \\
\hline
\end{tabular}

4 att Bolderwood not yet put out.

12 couple. besides what $\mathrm{y}^{\mathrm{r}}$ Grace has att Goodwood out of Young Madam \& Comfort. We have no more quarters in New Forest, except 2 to be kept at Bolderwood which I hope will be 2 of the 3 you have out of Crimson \& Cocker. 


\title{
Records of the Old Charlton Hunt
}

From Duke of Bolton, Newmarket, to the Duke of Richmond, in London.

Oct. 6, 1733.

My Dear Lord

I had the honour of your Grace's Letter $w^{\text {ch }}$ I would have answer'd $\mathrm{y}^{\circ}$ last post butt I was willing to Inform my self a bout the horfs of the man $y^{t}$ take's care of my stud: he says $w^{t}$ your Grace has here inclos'd. My Lord as he never was lame in his Life, \& $y^{t} I$ think him by much the best \& finest horse I ever saw, soe I was very desirous to have you have him. I desire you'l keep him \& hunt him, his price is $\mathrm{w}^{\mathrm{t}}$ you please, or if you'l doe me the Honour to accept* of him he is att your service. I shall be att Swakeley on Wensday next, \& I will waite on you in town if $I$ hear you are there for $I$ am $w^{\text {th }} y^{\mathrm{e}}$ greatest Esteem

\author{
My Lord \\ Your Graces most faithfull \\ Humble Ser ${ }^{t}$
}

BOLTON.

* Better still! 


\section{Records of the Old Charlton Hunt}

From Lord Delawarr, in London, to the Duke of Richmond, probably in France.

[Complaining that Lord Tankerville has crowded out the Duke of Richmond's hounds from the New Forest.]

Sept. 10, 1734 .

I never wanted you so much in my life as at present. That Dear Creature the Earl of Tankerville is Sending his Foxhounds into the Forest, Consequently yours must move for there is not Game for three Packs, I came to London about it and only desired him to stay till your Grace came over, that you might give orders where yours might go but to No Purpose. So I am returning, to go to Lord Lymingtons to day. This is hard \& I think your Friend Tanky uses you but very indifferently, for you will not have a whelp enterd; If I knew where I could Send them near Bear Forest I would instantly, to Findon would be eternal Ruin, because of the Sheep in the woods, too great temptation for young Hounds. I beg to hear from you, and as soon as I get down I will Send to see for some Place near Bear Forest. I am My $\mathrm{L}^{\mathrm{d}}$.

$\mathbf{Y}^{\mathbf{r}}$. Graces

Most faithfull

\& Obedient Servt.

Delawarr. 


\section{Records of the Old Charlton Hunt}

From Lord Delawarr, in the New Forest, to the Duke of Richmond, in France.**

MY LoRD.

Sept. 13, 1734.

I am to thank your Grace for the favour of yours of the 3 Ins $^{t}$ old S. from Paris. I rejoyce your Hounds I sent you have given you so much Pleasure, and acquitted themselves with so much honour when they encountered those of your Brother Grand Ecuyer. I luckily have A Couple of the Lancashire Chaps that were not able to proceed farther than London att that time. So we have the fewer to recruit for you. I have now good \& Bad News to Send you, the first is that your Hounds are well we have hunted six times and kill'd Six foxes, a Brace Yesterday, so miss'd but one Day and that was occassiond by A Violent Shower, for I think they ran harder that day than I ever saw them. The Bad is Andrews Black horse is Dead. He hunted one day last Week, was rid by Tom who rid no faster than I did on Scarborough. The Horse came home perfectly well in all appearance but lay down in about ten minutes and stretch'd himself out and died. I am sorry but 'Tom is mad, for he was A great Farourite. But as no neglect or Carelessness was the Occasion of this Misfortune I hope you will not have the worse Opinion of Old Tom. Especially now $\mathrm{M}^{\mathrm{r}}$. Milburn is dead, and John Shaw I

* The Dukedom of Aubigny in France devolved upon his Grace in 1734, and early in the following year he was appointed Master of the Horse to his Majesty, to which coming event Lord Delawarr probably refers in his mention of "your Brother Grand Ecuyer," evidently meaning the official that held the corresponding position in the Court of France. 


\section{Records of the Old Charlton Hunt}

Suppose Succeeds, So recommend Old 'Tom* to Succeed John Shaw, which is not recommending a bad Servant I assure you, But as he has always behaved well, desire his preferment. \& in it you will oblige My Lord

\section{Your Graces}

Most Faithfull \&

Obedient Servant

Delawarr.

From Lord Delawarr, at Bolderwood, to the Duke of Richmond.

Probably about 1736.

When I assure your Grace, that I heartily wish you were well enough to make me happy with your Company att Bolderwood, I flatter my self that you do not doubt but that my wishes are Sincere. I realy think we could shew you some sport. We had eight hours rain on Monday night, so Yesterday morning I sally'd forth with 21 couple of Hounds, we found a Brace of Foxes, and parted, Your humble Servant, My Groom, and Kit, went with the biggest Parcell, Jack Ware and Jo, with the others, who running up the Wind of us did not hear our Parcell, We ran him Very handsomely, an hour and a quarter, and then hard for half an hour more, he had just time to gett into a Coney borough the Hounds were so near him that a Couple got into the Earth, and kill'd him, we dug out Fox and Hounds in $\mathbf{A}$ quarter of an Hour and flung him to the Pack, for

* Tom Johnson. 


\section{Records of the Old Charlton Hunt}

Jack Ware, got to us with his Parcell just as we earth'd. I do not trouble you with the particular Names of the Places we ran to, because I beleive you do not remember them. But your Hounds perform'd well, and what pleases me much is, I did not See a Hound run to the Water nor lap coming home. I will be as good a Negus as I can, and hope I shall have the pleasure of bringing them in good order into Sussex, and finding your Grace there in good Health.

I have taken upon me a little but do beleive you will not disapprove, You must know that a little before I came down when they were airing the young hounds, the Boys got drunk and Jo was so drunk that he fell from his Horse, who came home, after having drank as much as he pleased, which had like to have killd him. (spit fire).* The Boy came home some time after in a drunken Condition, upon which my Old Wiszled face 'Tom rebuk'd him, replication ensued, and when I came I was acquainted with this affair, but after I had writ my last. I sent for him, and have assured him that if I See or hear any thing of the like for the future, I will take your Graces Livery from him, and send him about his business, he was much astonisht, and has promised never to do so any more, and I beleive the rough side of my Tongue may have done good. If I went too far you will excuse me for I meant it for your Service. I will be as little from them as possible, till the Parliament meets before which time I hope your Grace will be able to Hunt, for till their Brains are a little better settled, somebody must have an Eye over them. I went out this morning to Air the Young Hounds, they go very quietly, and do not so much

\footnotetext{
* The name of the horse.
} 


\section{Records of the Old Charlton Hunt}

as look att a Sheep, and will not offer to run att the Deer, how they will behave when they have found of a scent I cannot say. I hope you have not forgot to write about having the Kennell and Stables att Findon repair'd, pray order the 'Troughs for the Hounds to feed in to be mended if they want, or new ones to be made if these are past repairing; Consider the Time draws nigh. My most humble Service to her Grace and beleive me my Dear Duke your most faithfull

\& Obedient Servant

DeLawarr.

From Mr. Peachey, Newgrove? to the Duke of Richmond, at Charlton.

[Thanking him for not considering him a "Spoilsport."]

$\operatorname{Mr} L^{D}$ Jan. 19, 1737.

I receiv'd you Graces of the 16 th, $I$ am obliged to you for the just opinion that you entertain of me, that I would not disturb the sport of any Gentlemen, to which I must add, still less of any persons of Quality, and I assure you least of all that of your Grace. I keep finders which are half bred spaniels, \& a brace of Greyhounds perfectly for my health, \& the morning at this time of the year being to cold for old men, I goe out in the midle of the day, for about three or four hours, \& that is about three miles southward of my house, and never up the hill I can assure you that my finders can not hurt a fox, nor will they hunt him, nor when I kept hound did ever suffer them to hunt a 



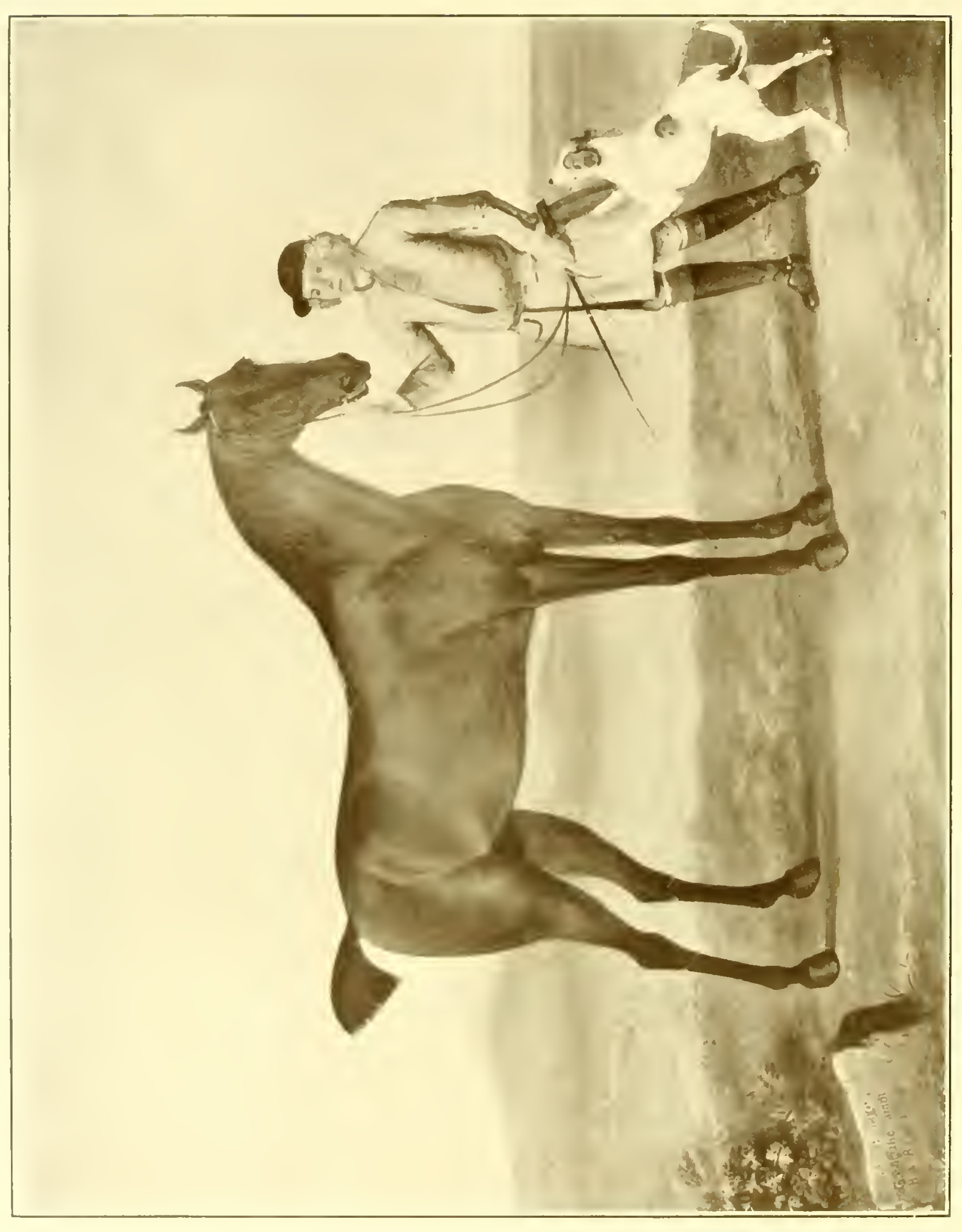

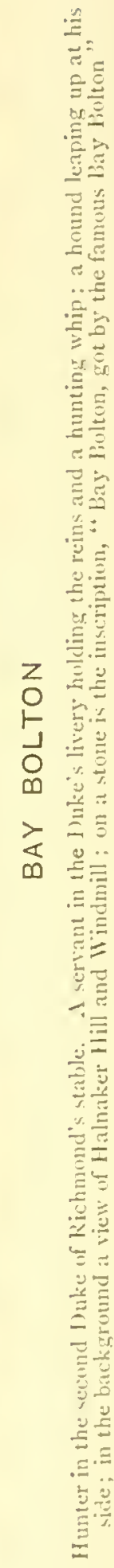




\section{Records of the Old Charlton Hunt}

fox, well knowin that it spoils Hariers, as for my dogs if they at any time are found running a fox, I desire they may be shot, and shal be well pleas'd with it, and if that practice be well follow'd as it should be, the fox hunters sport would in a litle time cease to be interrupted, $m y L^{\mathrm{d}} \mathrm{I}$ repeat it again that $I$ wish all dogs that follow foxes except the fox hounds, were shot constanly on seing it, and I give free liberty to any man to shoot mine on that occasion, and if $\mathbf{I}$ can in any thing be assistant in preventing the interruption of the sport of the Charlton Gentlemen, I shal willingly be serviceable in it, in this or any thing els, I shal be glad to shew all respect to your Grace being very truly

\section{Your Grace's}

Most obedient and

Most Humble Servant

$$
\text { J. C. Peacher.* }
$$

From the Duke of Bolton, New Forest, to the Duke of Richmond, Charlton.

["Alverstone" is in the Isle of Wight, of which place the Duke of Bolton was Governor, as well as being Warden and Keeper of the New Forest.]

My Dear Lord

Dec. 24, 1737.

I had the honour \& pleasure to receive your Grace's kind Letter last night, \& I am heartily glad to hear of your good sport \& $y^{t}$ your hound's doe soe well, I hope you find

* Bravo, Mr. Peachey!

135 


\section{Records of the Old Charlton Hunt}

the foxes as Stout as wee find $\mathrm{y}^{\mathrm{m}}$ here for they have generally run us very great Chase's before they are kill'd, I hope you have had better weather $\mathrm{y}^{\mathrm{n}}$ wee have had for this fortnight past for wee have bien outt butt three times, butt $\mathrm{y}^{\circ}$ good sport wee had make's some amend's, the foxe's hereabout's grow scarce soe in a weak or ten day I shall move to Aberstone \& $\mathrm{y}^{\mathrm{n}}$ I will send over to your Grace \& doe my self the honour to accept of your kind Invitation. I beg my Compliment's to my Bror. Foxhunter's \& hope you will doe me the Justice to beleive me Your Grace

Most faithfull Humble Srvt.

Bolton.

Major Brak desire's his Compliment's to $\mathrm{y}^{\mathrm{r}}$ Grace.

From Duke of St. Albans, Charlton, to the Duke of Richmond, in London.

Dec. $27,1737$.

I wish I could send $y^{u}$ a better account of our sport yesterday or $\mathrm{y}^{\mathrm{t}}$ we had killed a fox $\mathrm{w}^{\mathrm{ch}}$ we want to do very much at present, this being $\mathrm{y}^{\mathrm{e}}$ third time we have gone out $w^{\text {th }}$ out killing, \& the third of Delawar's going out $y^{t} \mathbf{I}$ suppose he is not to see a fox killed, he hunts Wednesday \& Friday \& Saturday goes away for $\mathrm{y}^{\mathrm{e}}$ New Forest, $\mathrm{y}^{\mathrm{t}}$ he may pofsibly hunt five times this year in Sufsex, for $\mathrm{w}^{\text {ch }}$ 'tis very well worth while to keep five hunters, we found att the Ruel he came out upon Slinden Common but was headed in by people att $\mathrm{y}^{\mathrm{e}}$ alehouse or $\mathrm{y}^{\mathrm{e}}$ Brig $^{\mathrm{r}} * \&$ his Boy (old 'Tom

* Probably Brigadier Hawley : see page 63. 


\section{Records of the Old Charlton Hunt}

says he wants as much rating as either Bumper or Dolly) but came out again a little lower \& so went orer $\mathrm{y}^{\mathrm{e}}$ Common to Earthom Common over Hanaker windmill Hill to Red Copse, where 'tis generally thought we changed, from thence thro' $\mathrm{y}^{\mathrm{e}}$ North hanger over Eastdean Lane to $\mathrm{y}^{\mathrm{e}}$ Parks to Strickland's fuzzes Round Rook's Hill to Westdean in a little copse he lay down a hare leaped up \& mett $\mathrm{y}^{\mathrm{e}}$ hounds as they were running for him $w^{\text {ch }}$ checked them a little $w^{\text {th }}$ a good deal of Hallowing gave Ren an opportunity of getting ground of them went back again to $y^{e}$ Fuzzes \& going up $\mathbf{y}^{\mathrm{e}}$ Hill by Tom Strickland's he was coursed by his dogs, so to my Lady Darby's \& then we lost him, a bitter cold day $\&$ a worse scenting day could not be, old Tom went out $\mathrm{w}^{\text {th }}$ us but was not able to ride, we found the want of his head more than once yesterday, $\mathbf{M}^{\mathrm{r}}$. C. Bifshop mett us at Madhurst as were going to $\mathrm{y}^{\ominus}$ Ruel, he stays here till $\mathrm{y}^{\mathrm{\theta}}$ Parliament meets, it was a pretty hard frost last night \& $y^{0}$ wind att North East, I hope we shall see $\mathrm{y}^{\mathrm{l}}$ on 'Thursday, I am My Dear Lord,

$\mathrm{Y}_{\mathrm{r}}$ Grace's most obedient servant $S^{T}$. Albans.

From Lord Delauarr, in the New Forest, to the Duke of Richmond, at Goodwood.

Undated, probably 1739.

According to your Graces Orders Tom Johnson attends you, I fancy if you take him to Lewis Races he may possibly find a horse there. In short you want five 


\title{
Records of the Old Charlton Hunt
}

horses, Tom Johnson 2. Nim Ives 1. Kit Bud 1. David 1. Tom will let you know how these are wanted.

If I have kept Doxy when you sent for her, you must Excuse me, but I thought she would be fed enough, and her bed good enough, in the Hall here, and I know you do not suffer a hound to come in your Parlour att Goodwood, but if you will have her I will send her.

As to Messieurs les Ministres, I have no sort of reason to think, I have been very well treated by them. Capt. Lynn and I have seen what it is to be honest, The Language the Duke us'd to me the other day, when I ask'd when I was to have the Company, was, would you have me kill a man? but in short I shall be att Hampton Court in about a fortnight, and the Devil may take the Governm ${ }^{t}$. for me, if I have not all that was promis'd me, for I swear I will fling it up.

I shall say nothing about the glorious number of hounds you have because you know it, but why 16 Couple of young ones; and the Madness amongst those left at Charlton; why will you not make quick work, where there is infection. God bless you, I wish Scarbrough* was better. I fear yet we shall loose him If that is the fate, I loose a friend, and the Ministry an Able Supporter. I am Dear Duke

\author{
$\mathrm{Y}^{\mathrm{r}}$ Most Faithfull \\ \& Obedient Servant \\ DeLawarr.
}

* Richard, 2nd Earl of Scarbrough, died in 1739. 


\section{Records of the Old Charlton Hunt}

From Duke of Grafton, London, to the Duke of Richmond, Charltor.

\section{My Dear LoRd}

Undated, probably 1739.

I am quite unhappy $y^{t}$ I cant accept of your offer of being at Charlton this year but as we have Hunted but little at Croyden we might loose $y^{e}$ right of being there shoud we goe away at this time when we have a good many Foxes likewise $\mathrm{y}^{\mathrm{e}}$ hounds are out of order \& some of $\mathbf{y}^{0}$ servants Horses not fitt to ride your Country, these you know are considerations in our Trade \& therefore pray beleive $\mathrm{y}^{t} \mathrm{I}$ am quite unhappy $\mathrm{y}^{\mathrm{t}} \mathrm{I}$ dont wait upon you when $\mathrm{y}^{\mathrm{e}}$ case is $\mathrm{y}^{\mathrm{t}}$ one loves both $\mathrm{y}^{\mathrm{e}}$ country and $\mathrm{y}^{\mathrm{e}}$ Gouvennour of It, I need not say. If It was pofsible I would be with you My Compliments to $\mathrm{y}^{\mathrm{e}}$ Duke of $\mathbf{S}^{\mathrm{t}}$. Albans, I wish you Good Sport \& better weather I am with Great truth your Graces Moft Obedient

Slave

Grafton. 


\section{Records of the Old Charlton Hunt}

From the Duke of Somerset, Petworth, to the Duke of Richmond, Charlton.

\section{My LoRD}

Jan. 26, 1739.

The most Exceeding kind visitt the Dutchess of Somerset and I Received yesterday morning from the Dutchess of Richmond and from your Grace, is now \& will upon all occasions bee acknowledged with a true sens of it \& this day wee desire to have the satisfaction to know that both your Grace's Returned Saffe \& well to Charlton. as I did perceive by the lookes of the Dutchess of Richmond horse to bee very well rode by soe noble and soe Great a Huntrefs to the very death of many ffoxes \& soe entirely to Her Grace's Satisfaction. I doe therefore take liberty to send your Grace the Receipt to make cerstiall Balles to bee given night \& morning to this Horse \& alsoe to your Grace's Hunters after every chace. the very same Balles I have more than ffivety yeares practiced \& my Horses used to receive very great Benefitt by them, as I hope yours will find the same good Effect upon using them. I send your Grace a small Pott of the Balles to bee used untill the Receipt dosse produce more by your own Apothecary.

wee wishe both your Grace's good weather which will add to the Pleasure \& agreeableness in Every ffox chace now \& at your return from London, in the mean time

* Does he mean crystal?

Charles, 6th Duke of Somerset, commonly called "The Proud Duke," died in 1748 at the advanced agre of 87 . 


\title{
Records of the Old Charlton Hunt
}

wee doe presume to fflatter our selves with Hopes of the Honour to see both your Grace's here some houres longer than yesterday.

I am with the utmost Respect \& Sincerely,

\author{
my Lord, \\ your Grace's most \\ ffaithfull and most \\ obedient humble servant
}

Somerset.

Wee are all in this House very true \& very humble Servants to both your Grace's

From the Duke of Bolton, Burleigh Lodge, New Forest, to the Duke of Richmond, Goodwood.

[Apparently suggesting that the New Forest is "overhunted"; but the letter is rather confusing.]

My Dear Lord,

March 28, 1740.

I came to this place yesterday, my hound's came here on Teusday the ground being soe dry att Sombourn $y^{t}$ I could not hunt there, they hunted on Wenesday \& kill'd an old dog fox att Lynwood, Your hounds had a very great Chase on Monday \& Earth'd in the Node's, they did not find on Wenesday in the low Country, I find foxe's wery Scarce in the forrest, I wen't outt to day \& drew a great deal of Likely Ground $w^{\text {th }}$ outt finding. As I hear $y^{t}$ Lord 


\section{Records of the Old Charlton Hunt}

Delawar's Warlike preparation's will prevent his coming hear this Season, if your Grace has a mind to see your hound's, you will doe me great honour \& pleasure if you will come to this place $w^{\text {th }} w^{\text {he }}$ ever Company you Like to bring $\mathbf{w}^{\text {th }}$ you, here is good Wine, butt noe french Cook, five bed's $\&$ only Perry, who can eat more $\mathrm{y}^{\mathrm{n}}$ any two people.

If your Affaire's won't admitt of your coming I should hope $\mathrm{y}^{\mathrm{t}}$ you would order your hounds to hun't noe more. It is noe more $\mathrm{y}^{\mathrm{n}} \mathrm{w}^{\mathrm{t}}$ my hound's shall doe $\mathrm{w}^{\mathrm{n}}$ I Leave them, for I think if wee both hun't separate wee need not think of coming here next year, the forrest is in good order, butt the Weather is very cold, I had a Vissitt from $M^{\mathrm{r}}$. Johnson this afternoon, I am $w^{\text {th }}$ great Esteem.

Your Grace's

Most Obediend

Humble Sert.

BoLToN.

From Lord Lincoln, Whitehall, to the Duke of Richmond, Charlton.

My dearest LoRd

Dec. $18,1742$.

I wrote you a letter last post full of despair, about $\mathbf{y}^{\mathrm{e}}$ cursed frost, but as thoughtlefs as Jack coul'd be for his soul, forgot to send it, $\mathrm{y}^{\mathrm{e}}$ frost I thank my Stars is over, so instead of a long, stupid, desponding letter, I will tell you ye contents of it in a very few words. I began with making apologies to $\mathrm{y}^{\mathrm{r}}$ Grace for not answering $\mathrm{y}^{\mathrm{r}}$ letter 


\section{Records of the Old Charlton Hunt}

sooner (which to be sure I shou'd have done) however, I laid $\mathrm{y}^{\mathrm{e}}$ fault upon $\mathrm{y}^{\mathrm{e}}$ Duke of Newcastle who constantly told me we shou'd have businefs in $\mathrm{y}^{\mathrm{e}}$ house of Lords which wou'd oblige $\mathrm{y}^{\mathrm{r}}$ Grace to come up to town, I $\mathrm{y}^{\mathrm{n}}$ said a thousand civil things to you for $\mathrm{y}^{\mathrm{r}}$ kind offer of a bed at Charlton, thank'd you over \& over for $\mathrm{y}^{\mathrm{e}}$ pains you have been so good as to take about $\mathrm{y}^{\mathrm{e}}$ Ballot, \& concluded with railing most damnably at $\mathrm{y}^{\mathrm{e}}$ weather, but now all is well, for it thaws most delightfully, and I flatter my self I shall soon have $\mathrm{y}^{\ominus}$ pleasure of being a member of Charlton, I fancy we shall be able to make up nine, if so, I shall have impudence enough to take it for granted I shall be chose, \& come down immediately

$$
\begin{gathered}
\text { I am } \mathrm{y}^{\mathbf{r}} \text { Graces } \\
\text { Most sincere friend } \\
\& \text { humble Servant } \\
\text { Lincolv. }
\end{gathered}
$$

From Lord Harcourt," London, to the Duke of Richmond, Charlton.

[Sporting and Political.]

MY LoRD

Dec. $18,1742$.

I received the letter Your Grace honoured me with, and I most heartyly condole with your Grace upon the badness of the weather. We had a fog last night which is

* Simon first Earl of Harcourt. Viceroy of Ireland in 1772. He was found drowned in a well in his park, having it was thought accidentally fallen in whilst trying to rescue a favourite dog, which was found in the well standing on his master's feet, the only part of him above the water. 


\section{Records of the Old Charlton Hunt}

not yet quite gone off, But the weather is milder than it was, and the wind is got a little more Southward, which may perhaps bring about a thaw. I have just seen a Coachman that I hope will do for your Grace's little horses, My Whip tells me he is a very sharp lad, \& likely to make as good a Workman as any in England, I have agreed with him for Nine pounds (wages) provided I like his Character, which I shall send to know imediatly. I have also heard of a Postillion, but I fear I shall have difficulty to get him, my Coachman tells me he does not weigh more than four Stone and a half, however as I know your Grace's horses, I shall not hire him, or any other upon report, but by weight, If I can find one to my likeing, I shall send him to Will Manning, who may enclose him in a letter to your Grace or have him conveyed to Goodwood some other way. If the weather should allow us to meet your Grace at Charlton, you may depend upon my best endeavours to muster as many of our members as possible, thô I despair of bringing the whole number togeather. I saw Jack Mordaunt yesterday, and he seems very desirous of going to Charlton, he says he has been there with the Duke of Bolton, which he hopes will entitle him to a Seat in Fox hall, however I believe nobody will pretend to give an opinion in an affair so important, till Your Grace shall declare your Sentiments, Now for Politicks $S^{\mathbf{r}}$ Harry's differing from the rest of his friends in the vote he gave, was a most disagreeable thing, I love and value him so much, that $I$ think his giving a vote with the Opposition, upon such a question was too great an honour to them, for it gave them an opportunity of flattering themselves, that there was one honest man of their opinion, which I hope will never be the case again. 


\section{Records of the Old Charlton Hunt}

Your Grace knows $\mathbf{S}^{\mathbf{r}}$ Harry was for the Hannover troops, the vote he gave was against allowing the Levee Money, which between friends I think a most dirty affair, and I fear will do more mischief to the cause, than the money allowed can do service to—_ At least I look upon it in such a light, that inconsiderable as I am, I would have given a good deal out of my own pocket, rather than to have seen the discredit of such a demand, \& the mischief it may do to his Majesty \& the Whig cause. I am My Lord thô in a most round about way

\section{Your Grace's ever}

Obliged friend, \& Humble Servant

Harcourt.

My compliments to $\mathrm{y}^{\mathrm{e}}$ Dutchess, Henry Cheale,* Day Rolle, \& my friend $\mathrm{L}^{\mathrm{a}}$ George.

From Lord Harcourt, London, to the Duke of Richmond, Charlion.

My Lord

Dec. 15, 1743.

I had the pleasure of waiting upon the Dutchess of Richmond the night before last, and of finding her Grace perfectly well. She told me that she expected your Grace in town on Saturday next, which tempted me to put off my journey to Charlton till about tuesday next, when I

* Norroy King at Arms. 


\section{Records of the Old Charlton Hunt}

am informed your Grace proposes to return to Charlton, at which time I shall be glad of the honour of attending you. I propose to stay a fortnight at Charlton, which the Duke of $\mathbf{S}^{t}$ Albans will scarce believe. What I shall do there is another question, for I dont know whether I have a horse to ride, for I have had but a bad account, of a horse I had from $y^{\mathrm{e}}$ Duke of Boltons upon which I had great dependence. However let that be as it will, the company of my friends, Good Punch, and a pipe of Tobacco will make Charlton go down very well. General Wade kissed his Majesty's hand yesterday upon being appointed Field Marshall, and Comander in chief of the troops abroad. The Scotch that were present looked as I fancy their countrymen did, that were executed in the tower some time ago. However I heard some of them say, this morning, By God we must wait upon him, tho perhaps it is not the promotion we most approve of.

There was this morning a motion in the House of Commons for an address to be presented to His Majesty, that he would be pleased to enter into no new engagements for the support of the Queen of Hungary, unless in concurrence with the Dutch. 'Tho these are not precisely the words yet they were much to this purpose, tho with the addition of some aggravating expressions, that might possibly create a debate. 'The particulars of which I suppose Mr. Pelham will receive by this nights post. 'Thô if the treat your Grace intends is be to morrow as I am informed it is, your Grace may possibly have other busyness to transact. Had I thought Mr. Pelham's Election would have admitted of sobriety, I should have done my self the honour of attending it. But to play the fool as I did at 


\section{Records of the Old Charlton Hunt}

Lewes is what I hope will not happen to me again. Lord Falmouth has spoke to Lord Carteret and I believe to the Duke of Newcastle for my friend Jack Boscawen to succeed Captain Strickland, who two or three days ago gave up the Comission he had in the horse Grenadiers. As by the turn of affairs my friend may now reasonably expect some preferment I should look upon it as the greatest of farours, if you would speak a word to Mr. Pellham to concurr with them in their recommendations in case they should undertake to serve him. I am My Lord with the Greatest truth

Your much obliged humble Servant

HARCOUn'T.

Mr. Solomon Dayrolles, Euston, to the Duke of Richmond, Goodwood.

MY LoRD

Oct. 6,1744 .

According to Your Grace's directions, I wou'd have taken the liberty to trouble you before this time with a letter, had any thing occurr'd worth intruding upon a few minutes of your leisure. There was ne'er a good Fox Chace that I cou'd give you an account of, and it wou'd have neither moved your pity nor given you any Entertainment, had I inform'd Your Grace of the exquisite and unaccountable pains I suffer'd in one of my Feet, when I lay at Chesterford in my way to Euston, and told you the discourse I had with a Physician that happen'd then to be in the House, who declared to me, (tho' he did not say it to 


\section{Records of the Old Charlton Hunt}

frighten $\mathrm{Me}$ ) that it was the forerunner of some dreadfull distemper, and that the shortest and safest method to cure my complaint, wou'd be to apply directly a Caustick to my Foot. This terrible Sentence did not however prevent my coming here, and it has had no other bad Consequence than the lofs of a very good Chace this day sennight. Since that I have been out three times. The first day we found two Foxes but lost them both in a very little while. 'The second day we kill'd one in his kennel, run another about five miles and then lost him. 'This morning we had a chace of about an Hour and very hard running, but the Fox was headed and lost. Here I must again make mention of Myself and perhaps move Your Grace's compafsion, tho' the Duke of Grafton had no more bowels than a Flint: tout au Contraire, exprefs' Choler ; but this was more owing to his disapointment than to my misbehaviour. As I was galoping over one of his Heaths, my Horse struck into a Conny burrow, fell down flat upon his side and flung $\mathrm{Me}$ some Yards before him with my side against an Old Mole Hill. It was such a bang that I was speechlefs for some time, however I mounted my stead again, and when this Grace came up with me, I was comforted in the same manner as Job was by his Friends. After this we tried for another Fox, but my pains increasing I went home to be Doctor'd a little, but finding myself better after some inward \& outward applications, I return'd to the Company when in my way I spied Renny who had stolen away from bchind the Hounds. I then gave them a view hollow, brought them back, run him for an hour and a quarter orer the finest part of this Country, and kill'd him with the whole Pack at his Brush. 'This has made his 


\section{Records of the Old Charlton Hunt}

Grace unknit his Brow, and curse the Rabbits and their Burrows. To-morrow he sets out for London and is to be here again next monday. For my part I remain here. We have had $\mathbf{M}^{\mathrm{r}}$. Hardenberg here this week, in his way to Mylord Orford \& Mylord Lovel qu'il est bien aise de connoitre. I hope Mylady Duchefs and all your Graces family continue in perfect health. My I beg the favour of my very humble respects to Her Grace and to Lady Emily. I am with the greatest truth and respect

Your Grace's

Most Obedient

Humble Servant

S. Dayrolise.

Mylord The Duke of Grafton Mylord Bishop of Landaff and Baron Hardenberg desire their Compliments to $\mathrm{Y}^{\mathrm{r}}$ Grace \& to My Lady Dutches.

From Colonel Martin,* Fortwilliam, N.B., to the Duke of Richmond, Goodwood.

MY LoRd Duke

May $14,1745$.

I am glad to find Your Grace has not left off Fox hunting which I suppose is Your divertion in $\mathrm{y}^{\mathrm{c}}$ New Forrest. No body is more strongly prejudiced for bodily Exercise than myself, who have allways ufed it and I fancy it has

* He took an active part in suppressing the Rebellion of '45 and subsequent campaigns on the Continent. 


\section{Records of the Old Charlton Hunt}

preserved my Agility \& Vigor beyond many I see Younger $\&$ of better Constitution than myself. Col. Gardiner since he is growing rich \& Lazy is $\mathrm{y}^{\mathrm{e}}$ most alterd man $\mathrm{I}$ have seen in so short a time, he stoops, pockes out his head, and has $\mathrm{y}^{\mathrm{e}}$ appearance of a Very Old Man.

I am sorry I can't have $\mathrm{y}^{\mathrm{e}}$ happinefs to be in an old Corps for I am terribly affraid of a reduction; I think verily this War is too Expensive to laft long, if there is no better Economie of $\mathbf{y}^{\mathrm{e}}$ publique mony than there is here. You Gentlemen who pay so largely to support $y^{\mathrm{e}}$ State must soon grow weary of it. 'They are making a peice of road here to pleafe one Great Man that he may drive eafily to his houfe (when he gets one) tis about 40 miles where there is to be 17 bridges one will cost 2 or $3000 \mathcal{E}$ thro' a country all rock \& Bogg, where nobody will ever have occafion to pafs but he himfelf \& that perhaps but once more in his life if he does that. The roads $\mathrm{y}^{\mathrm{t}}$ are made allready by $\mathbf{M}^{\mathrm{r}}$. Wade are very good of themselfs especially to $\mathrm{y}^{\mathrm{e}}$ man he has appointed to look after them, but of very little ufe to $\mathrm{y}^{\mathrm{e}}$ publique for theres neither lodging meat or drink or horses or Carriages to be got on them. I have lately pafsd 4 times thro' thefe West highlands where there is no road or hardly track but $y_{?}^{\mathrm{e}}$ mountains stand all round like a parcel of sugar loaves on a grocers counter, where I got nothing to Eate or drink but what $I$ carried $w^{\text {th }}$ me, and at night no bed to lye on. Your Grace may well call this a curfed Country; and I muft beg leave to Anathemize the animals bred in it, for the 'Tartars themfelfs are not half so Savage as $\mathrm{y}^{\mathrm{e}}$ common highlanders. 'The Gentry are so proud \& National there is no conversing with them, they are at home quite different from what you see them about $y^{\mathrm{e}}$ Court. 'To give You a small 


\title{
Records of the Old Charlton Hunt
}

instance of what they are, \& how they are affected to us of $\mathrm{y}^{\mathrm{e}}$ South, a Gent ${ }^{\mathrm{n}}$. of quality where I was laft quarterd was very shy of being acquainted $w^{\text {th }}$ me till he saw I was known to a certain Earl $w^{\text {th }}$ a Green Ruban a great speaker in Your houfe, he afked $y^{e}$ Earl what sort of man I was, he reply'd a good sort of man, one of $y^{e}$ beft that come from that Country. All $\mathrm{y}^{\ominus}$ Good Gen!. Wade did for this country by laying out ... Thousands of $\mathrm{y}^{e}$ Governm $^{\text {ts }}$. mony to . . . purpofe can't procure a good word from any of them, they say he is no friend to Scotland $w^{\text {ch }}$ a man muft be, or pretend to be, or he cant live here.

\author{
My Lord Duke \\ Your Graces most Obed'. Servant \\ B. M. Martin.
}

From Mr. Pauncefort, Early Court, to the Duke of Richmond, Charlton.

My Lord Duke,

Jan. 25, 1747.

I have just now received a printed Summons to meet the Gentlemen of the Charlton hunt, or send an Answer by Friday, the latter was impossible for me to perform; the former indeed I might, was I not grown desperate enough to own that I could not stay longer in town from a Young Mistrefs I keep in the Country of 3 year's old; \& my Mother who I had left not so well as I could wish. I must therefore make an Apology for not waiting on your Grace on Wednesday (tho' as yet have had no Summons) since had 


\title{
Records of the Old Charlton Hunt
}

I staid in town, it would have prevented me the pleasure of attending Your Grace at Charlton $w^{\text {ch }}$ I propose soberly to perform; that is, only to be drunk once a day after dinner $w^{\text {th }}$ your Grace and then go write. Pray warn Mr. Conolly out of my Stables I shall fill the whole.

\author{
I am \\ $\mathrm{Y}^{\mathrm{r}}$ Graces \\ most Obed ${ }^{t}$. Serv ${ }^{t}$. \\ Edw ${ }^{\text {. Pauncefort. }}$
}

From Lord Delawarr to the Duke of Richmond, at Bolderwood, New Forest.

MY LoRD.

April 17, 1747.

I have as great Happiness as I can (when deprived waiting on your Grace) in hearing that every thing within Doors att Bolderwood has been to your Satisfaction, and that Nanny has play'd her part well as to the sorts of Provisions you like, being very desirous that whatever Place I have any thing to do in may be agreeable to you. I am glad you approve of the New Building, I think it will make the whole very convenient, and prevent your being so much straigned another Season; but when I think how uncertain the modern Sportsmen are, I then imagine any house will be large enough. Your Grace was right when you thought the room above Stairs was for the Books, they are to be put there as soon as it is finished and dry, for the room where they are now will be a passage room to the Bow 


\section{Records of the Old Charlton Hunt}

Window room on that floor, When Miss Wests are att Bolderwood their Harpsicord will be also put there, so that I intend it as a Family assembly room, which as it has no communication with the old house, but by the new Stair case, will yet remain quite private if any Strangers dine with me, or if any very ceremonious person should by some great miracle lay a night there. I now proceed to give you my reasons for putting wainscot in the Stone Parlour. That room is intended only for dining in when I come from shooting in Winter, or with a small Company; as the Guns, Hats, Canes, Shot pouches, Dog couples, and many such like ornaments, will be hung up there, the putting up of pegs would be always making Holes in the Stucco, and as the room is so fmall the Servants moving the Chairs and Table would be eternally damaging the Stucco which would ruffle my Sweet Temper. The other rooms are to be stucco, only because it is cheaper for I own I do not love it, because of the Eccho, which makes such a Confusion of Sound, one cannot, without better Ears than mine, hear one another Speak distinctly. As to the Square Holes over the Chimney, I was told it was to save Bricks, and discharge the Weight from each Arch of the Chimney, it will be stop'd up in my stone parlour, but in the next it will make an Excellent Cupboard for Madam Thorton to keep Sweatmeats and Sugars very dry_- I hope you have had, as much rain as we had last Wednesday Evening, that and the Wind now changing will contribute to your Sport, which I wish quite to your Grace's Satisfaction. To be sure New hounds in a pack never show att first, but I have always heard, from those that used to crack them up, only of their very hard running, which caused me to doubt with 


\section{Records of the Old Charlton Hunt}

my Self whither they were good nosed ones, and good beaters; your Grace will let me know that, for I never saw them in my Life. The Duke of Newcastle tells me he has wrote you all the news, so I do not presume to say one word on that subject. I desire my Compliments to all your Company and that you will beleive me to be with the greatest 'Truth $\mathrm{Y}^{\mathrm{r}}$ Graces

\section{Most Faithfull and}

Obedient Servant

Delawarr.

From Lord Delawarr, in London, to the Duke of Richmond, at Bolderwood.

MY LoRD.

April 21, 1748.

I had the Honour of your Graces from Bolderwood, and am glad you found that Place in such tollerable condition, as to make me hope the continuance of your favour to it. I can assure you, and I flatter my self you think me sincere, that one of the greatest Pleasures in the additions I made to the House was proposing by that, to be able to accommodate your Grace rather better, than with what you had been so good heretofore to take up with. I think it now enough, and convenient, and hope to have some Comfort there, tho as yet have had very little pleasure, from the uncertainty of the times, for some years past. If Peace should come, I wish it may soon; I may then hope 


\section{Records of the Old Charlton Hunt}

to have again some merry hours with your Grace in the Forest, and att Charlton, and if a Birth day does not fall out regularly att Bolderwood, we must make one ; and Charlton I beleive generally every day is such. I am glad to find Nanny keeps in your good graces, I dare answer she had your bed well aird. And hope she will take care you want not calverd Salmon or any thing else that country affords. As to your proposal of planting, put in as many trees as you please, and where you will, thô it is to be sure the worst place in the world for that sport, I have planted hundreds without any Success, and therefore would advise planting them in basketts, I have tryed every other way. The Earl of Lincoln sett out this day in order to hunt with you on Saturday; I beg you to keep him in some order, for killing a Heath hen, or Partridge on the Heath, att this Time is destruction. And tho I do not look on his Lordship as a very excellent shot, yet I know by experience that a Gun is A very dangerous instrument, for I remember to have Seen A Gun go off in the late Lord Sussex's (Totty Sussex we calld him) hand; and he killd a Partridge, tho he was looking another way, and did not see the couvée.* I must own your Grace was very alert, to sally forth immediately on the going off, of the Snow, I hope now the wind is come to the West, you will have better weather, and better Sport, and should that lead the Earl into a Bog, I hope you will not conceal it from me. Who have you got with you? If Pauncefort, I then suppose he takes up his Habitation in the Library which I beleive he does not

* How history repeats itself! For is not the very same feat recorded in the 'Pickwick Papers' as having been performed by the immortal Mr. Tracy Tupman? 


\section{Records of the Old Charlton Hunt}

think an unpleasant room. My Compliments to all I know, and do me the Justice to beleive $\mathbf{I}$ am with the greatest Truth My Lord

\section{Your Graces}

Most Humble and

Obedient Servant

Delawarr.

From Lord Delawar, Bolderwood, to the Duke of Richmond, in London.

[" Heath Poults" must have been black game.]

MY LORD,

Aug. $10(3), 1748$.

I am favourd with your Graces commands by Bud, and send you two brace of Poults, that were kill'd on Saturday, and immediately Stuff'd with Heath as they were intended to be sent to you by $M^{r}$. Poole, but as he has put off his journey for one day more, I send these by the Bearer, and if we have any success this Day, will send you some more by $\mathbf{M}^{r}$. Poole, I sent two brace by John Rowe which I hope came good. Lord Ilchester has some complaint that he writes me word makes him incapable of riding, So that he could not come, as he intended, but if I see him this week I will not fail to give him your message. I propose staying here a fortnight longer and then paying my Respects to your Grace att Goodwood, and hope you and Lady Dutchess 


\section{Records of the Old Charlton Hunt}

will give us Leave to bring Miss Poole with us. I desire my Compliments to Lady Dutchess and that you will beleive me with the greatest Truth My Lord

\section{Your Graces}

Most Humble and

Obedient Servant

Delawarr.

I never Saw your Hounds look finer in my Life.

From Lord Delawarr, Bolderwood, to the Duke of Richmond, in London.

MY LORD

Aug. 14, 1748.

I am glad the Heath Poults came safe to your Grace and that they were so much to your Satisfaction. As to the Affair of the Trap I can explain that to you when I see your Grace for I bought them my self, and they are to set on Bushes to catch the Hawks and Kites, thô when this was taken up it was from one of the Dog Houses att the Stable your Graces Hunters stand in. it was put every night before the Hole where a Hen was sitting, and throw'd in the morning; when she had hatch'd, the 'Trap was left in the Place, and they carried it to Smith, who a little while ago brought it to nanny again, but Some sort of Foxes or other have had so many out of fourscore Chickens, that I have none but what I buy; And I am sure they are plenty, for $\mathbf{M}^{\mathrm{r}}$. Poole was surprized to kick them up in the Fern as we were 


\section{Records of the Old Charlton Hunt}

Shooting, and that near the House. I shall trouble your Grace with another Letter before I leave this Place but I think We shall have the Honour of kissing your Graces hands either the $23^{\text {d }}$ or $24^{\text {th }}$. I am with the greatest Truth My Lord

\section{Your Graces}

Most Humble and

Obedient Servant

DeLawarr.

From Lord Eglintoune, Somerley, New Forest, to the Duke of Richmond, Goodwood or Charlton, asking for two hounds.

\section{My Lord Duke}

Oct. $29,1749$.

I am extremely glad to hear of your Grace's safe arrival in this country as it renews our hopes of seeing your Grace in this wild part of the world before the fox hunting season is quite over. I have been out with your Graces hounds \& have the pleasure to afsure you they are rather better than last season if that is pofsible. Those your Grace had from Sir Charles Goring are remarkable good hunters but I am apt to think there are some of them which will not run so hard as your Graces old sort towards the latter end of the day.

There are a couple of old bitches which Smith and John Row * think too much wore out to breed out of and not

* John Smith succeeded Tom Johnson as huntsman; John Row was 1st whipper-in. 


\section{Records of the Old Charlton Hunt}

able to run if your Grace thinks them neither an ornament nor of use to your pack I should be extremely obliged to your Grace to place them in mine where they may still make a figure at least in the way of gallantry as I am of opinion (notwithstanding what those learned gentlemen say) that the chip of an old block is often as good as the sprouts of a young tree. I have the honour to be with the greatest respect.

\section{My Lord Duke \\ Your Graces}

most obedient and

most humble Servant

Eglintoune.

From the Earl of Dalkeith, Adderbury near Banbury, thanking the Duke of Richmond for the offer of some hounds.

MY LORD

Dec. 17,1749 .

Since I had the Honor of seeing Your Grace I have laid aside for the present the Scheme I had of Hunting Fox with My Harriers, in performance of a promise I some time ago made to $\mathbf{M}^{\mathrm{r}}$. Selby (who has an House within two Miles of this Place) not to Hunt upon Edge Hills after $\mathbf{L}^{\mathrm{d}}$.

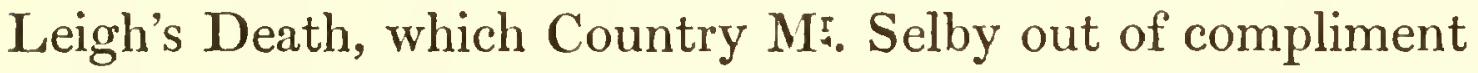
to $\mathrm{L}^{\mathrm{d}}$. Leigh never went into, or more properly out of compliment to $\mathbf{L}^{\mathrm{d}}$. Leigh's Huntsman, as $\mathbf{L}^{\mathrm{d}}$. Leigh never came upon the Hills himself. I am very much Obliged to Your Grace for thinking of me, and return you a great 


\section{Records of the Old Charlton Hunt}

many thanks for your kind offer, a Present of the same sort will be very acceptable to $\mathrm{me}$, if $\mathbf{M}^{\mathrm{rs}}$. Selby should at any time grow tired either of His Hounds or of this Country. I am extreamly glad to hear Your Grace has had good Sport, and I should think Myself very happy if it was in My Power to wait on You this Christmas ; I fully intend to have the Pleasure of attending Your Grace at Charlton in February, and I shall always remain with the utmost gratitude and sincerity Your Grace's

\section{Most Obliged and \\ Faithfull Servant \\ DAlKeith.}

From Lord Eglintoune, Somerley, New Forest, to the Duke of Richmond, in London.

[Thanking him for two hounds, and regretting that he should have been wrongfully accused of encroaching upon the Duke's country.]

My Lord Duke

Dec. 29, 1749.

I return your Grace a thousand thanks for the two bitches your Grace may be sure they shall be taken particular care of both on account of their own merit and the person who gave them. I am sorry your Grace should have been told that I have been destroying your hunt, I promis'd your Grace I would not hunt that part of the forrest and as I have most religiously kept my word I cannot help thinking that I am the only person has rason to 160 


\section{Records of the Old Charlton Hunt}

complain as your Grace seems to credit such information. Were I by chance my Lord to kill one of your foxes I do afsure you I would be the first person to acquaint your Grace of it myself. Tis true there has been a brace of foxes killd in the upper part of the forrest by my hounds but they were neither of them found there and I dare say your Grace is too keen a sportsman to desire I should not follow them I shall not trouble your Grace any further about this affair at present but shall do myself the honour to wait on your Grace the moment I come to Town and make no doubt I shall satisfie you as to that matter mean while I hope your Grace will do me the justice to believe that there is nobody to whom I should be more sory to give cause of complaint and that I have the honour to be with the greatest sincerity

$$
\begin{aligned}
& \text { My Lord Duke } \\
& \text { Your Graces } \\
& \text { most obedient and most } \\
& \text { Humble Servant }
\end{aligned}
$$

Eglintoune.

From the Duke of Grafton, in London, to the Duke of Richmond, at Charlton.

Dear Duke

Undated.

According to your Commands I send you Render, he is an old Hound, has no Ill qualities so $\mathrm{y}^{\mathrm{t}}$ he may be Hunted, never was lame in $\mathbf{y}^{\ominus}$ Shoulders till this seafon, which has been $\mathrm{y}^{\mathrm{e}} \mathrm{Cafe}$ of severall others (nothing has been done to 


\section{Records of the Old Charlton Hunt}

him for It) my old Friend Fregus whofe voice I rememberd, gives an account of many fine chafes $\mathrm{y}^{\mathrm{t}}$ you have had, but tells me emphatically, $\mathrm{y}^{\mathrm{t}}$ they have all been since $\mathrm{y}^{\mathrm{e}} \mathbf{L}^{\mathrm{d}}$ Delawar came away, by his repitifion of this fact, I shou'd fear my noble friend is not in $\mathrm{y}^{\mathrm{e}}$ good Graces of $\mathrm{y}^{\mathrm{e}}$ Bafe cour at Charlton. we have had two or three days good sport togeather; yefterday we had $\mathrm{y}^{\mathrm{e}}$ beft chafe for three hours $y^{t} I$ have seen this many a day I dont know $y^{t} y^{e}$ hounds were at a fault in $y^{\mathrm{e}}$ whole time we were once near twenty miles from $\mathrm{y}^{\mathrm{e}}$ Place we found him. Moft of our Horfes were near up, being in a steep Country by Aylsford in Kent were I never was before. my Compliments to all $\mathrm{y}^{\mathrm{e}}$ good Company, with my refpects to Her Grace

I am your slave

Grafton.

It is now ten at night, my servant $\mathrm{y}^{t}$ went this morning is not come from Croydon I wifh $\mathrm{y}^{\mathrm{e}}$ Hound did not goe out with ten Couple $\mathrm{y}^{\mathrm{t}}$ were left at Euston \& are juft brought up \& Hunted to day.**

* I cannot make head or tail of this sentence! I gather, however, that " $\mathrm{Y}^{\circ}$ Hound" is intended by his Grace as an uncomplimentary reference to his servant; beyond that the meaning is obscure. 


\section{CHAP'TER XI}

\section{THE 'SUSSEX GARLAND' \\ (FROM THE HOUND PEDIGREE BOOK)}

These verses are taken from the pages of the ragged old manuscript book which contains the names of the Hounds, their Pedigrees, and the accounts of the Annual Meetings of the Charlton Hunt. What particular station in life was filled by Jack Budd of Charlton I know not; but from the fact that several members of the Hunt kept their horses in his Stables, and that he himself was a regular follower of the hounds, I should imagine that he was a sporting farmer, or something of that description. And it is not difficult to imagine a pressing invitation being sent from Fox Hall, now and again of a winter's evening, to Mr. Jack Budd, expressing a hope that he would join the Gentlemen of Charlton over their wine; cannot we picture his jolly flushed face, as in broad Sussex accents he trolled forth those home-made stanzas of his, whilst the glasses and decanters danced and rattled on the table, and the rafters of the Great Hall rang with the rollicking chorus that followed each verse? 


\section{Records of the Old Charlton Hunt}

\section{THE SUSSEX GARLAND BY JOHN BUD OF CHARLTON.}

1.

Charlton December twenty eight

Att half an hour past nine

His Graces loitering made it late

Yet we a Fox did find

In East dean Wood; 'twas Kitty cross'd

Hark in, get on or you'l be lost

With a Hark Kitty, hark in hark.

2.

Ore Northern Down, all up the wind

Go on to Burnt Oak Gate

We all of us just there got in

The Hounds ran a great rate

Away they went for Herring Dean

Att Cocking road they turnd again

With a Hark forward hark on hark.

3.

Then down the Wind ore Cocking Course

Each man did push his Horse

'To 'Tegleese gate, where Huntsman like

We stopd to see them cross

There first came Veny, Luther next

Young 'Trojan, Victor, then the rest

With a Hark forward hark on Hark.

164 


\section{Records of the Old Charlton Hunt}

4.

Then ore the Hills for Sheep wash Earth

Twas stop'd, it would not do

From thence to Burton hanger Strait

They ran as if in View

Att Glatten Beacon up he came

But there was headed down again

With a hark Victor hark in Hark.

5.

Of all the Hounds of any Breed

Sure Victor is the Best

There he and Trojan took the lead

And kept it from the rest.

To West Burton \& ore Berry hill

They had no Check nor n'ere stood still

With a Hark forward, hark on, hark.

6.

But there some Sheep did cause a stop

A Minute and no more,

For Victor cast, and hit it off,

For Preistcombe on before,

The Hounds they heard him, and came in,

For Horton Cliffs, they ran amain,

With a Hark Victor, hark on hark, 


\section{Records of the Old Charlton Hunt}

7.

Just by the Earth poor Ren was seen,

The Chace was not yet done.

Jack Ware leapt off', and strait brush'd in,

But Ren did further run.

Now all att Fault, both Man and Hound

Jack would conclude him gone to ground

With a Hoax cross him, hark again, hoax.

8.

Just then we heard a Halloo Clear

A Mile up wind att least

Hark halloo strait get up Jack Ware

This Trick it is his last

Away we went to Houghton Town

He there had bob'd all up and down,

With a Hark halloo, hark in hark.

9.

Through Farmers Yards, and their Wife hole,

We drove him all about

We saw him leap ore pales \& Walls

Att last he did get out

Then for Preistcomb again he ran

But att the Hedge was att a stand

With a Whooup, Whooup, Whooup. 


\section{Records of the Old Charlton Hunt}

10.

His Grace of Richmond then and there

For to compleat the Day

Did get a Fall both fine \& fair

From off old Cary grey

While some did laugh his Grace said nought

But att John Shaw let fly a stroke

With a Hey day what now what now.

11.

Now I must tell you who they were

That rid this noble chace

First then was John Lord Delaware

Ive told you of his Grace

Next Jenison, a Northern Knight

Of Shire, \& Hawley a light weight

With a Hey for Goodwood, hark away hark.

12.

Tho last of all yet first in fame

Of Sportsmen that we know

Old Andrew sure I now must name

And best Companion too

He knows the Hounds and what they do

Can Ride and Drink and make Love too

With a Fal a la la. 


\section{Records of the Old Charlton Hunt}

1.

There were three Jolly Huntsmen

And they would a Fox

And went to find old Reynards

Amongst the Woods \& Rocks

With a Hoop, Hoop Hallow, Hark on Brave Boys

Hark Away, the Huntsman Cry'd

With a 'Twink, 'Twink, Twink, \& a Twivee 'Twivee Twink

As we from the Kennel did ride Boys,

As we from the Kennel did ride.

2.

We threw into the Cover

To see what we could find

And soon we spyd Old Reynolds

Tripping it down the wind

With a Hoop Hoop Hallow hark on brave Boys

Tallie hors, the Huntsman Cryd

With a Twink, \&c.

And down the wind we did ride Boys, \&c.

3.

'The Huntsman cry'd Away Hark Away

The Hounds together stuck

And Bravely they pursued him

And crossed over the Brook

With a Hoop Hoop Hallow Hark on Brave Boys

Hark forward the Huntsman cry'd

With a 'Twink, \&c.

And over the Brook we did ride Boys, \&c. 


\section{Records of the Old Charlton Hunt}

4.

We being brisk and Airy

Did Gallop over the Plain

Whilst Emperor and Henry

The Chace they did maintain

With a Hoop, Hoop, Hallow, Hark on Brave Boys

Aye thats Good The Huntsman cryd

With a Twink, \&c.

And over the Plain we did ride Boys, \&c.

5.

Att lengthi we saw an Old Shepherd

As we were ganging along

And there we spyd old Reynolds

The Ews and Lambs among

With a Hoop, Hoop, Hallow hark on brave Boys

Whooo The Huntsman cryd

With a Twink, \&c.

And over the Plain we, \&c.

6.

Poor Reynolds being weary

Could neither goe nor stand

And now he must surrender

And be att our Command

With a Hoop, Hoop, Hallow hark on brave boys

Whoo Whoop The Huntsman cryd

With a Twink, \&c.

And so poor Reynold dyd Boys

And so poor Reynold dy'd. 


\section{Records of the Old Charlton Hunt}

1.

Cove listen awhile

Of Fox hunting I will sing

Which on our Sussex downs

Is sport for any King

And to Sussex we will go, \&c.

2.

That all men are sportsmen

I hold for to be true

For some scent or another

Each man he doth pursue

And a Hunting we will go, \&c.

3.

Some Hunt after Riches

While others seek the Chace

But they who love a keener sport

Will hunt a pretty face

And a Hunting we will, \&c.

4.

All on a Morning fair

To Eastdean Wood we went*

'To hunt a Captain Fox

It being our Intent

And a Hunting we did go, \&c.

* This song quite probably may have been descriptive of the Great Chase of Jan. 26, 1738, from East Dean Wood. 


\section{Records of the Old Charlton Hunt}

5.

'This Fox having defeated

A Duke I shall not name

We were resolved to Hunt him

For to revenge the same

And a Hunting, \&c. 


\section{CHAP'IER XII}

\section{AMUSING RECEIP'TS FOR THE BITE OF A MAD DOG}

From the Hound Book, again, I extract the quaint Prescriptions which follow.

Truly our ancestors were valiant men! For surely "Scrap'd Pewter" strikes one as being a curious ingredient wherewith to compose physic for a poisoned system-but perhaps the Strong Ale and Treacle may have had a good deal to do with rendering it, if not wholly innocuous, at any rate more or less digestible. And, as regards Doctor Mead's Receipt-he, by the way, was the Duke's medical adviser for many years-it is evids nt that he relied largely upon the efficacy of cold water as a panacea for the disorders of his day. Well-perhaps he was right! For there are those that darkly assert (and low be it whispered) that, in spite of the glamour and romance with which we love to envelop the days of powder and patches, a bath of any sort was such a rarity that the mere fact of prescribing a cold bath daily for a month would have been sufficient in itself to terrify any invalid into rude health, without any further demand upon the weird nostrums of the apothecary of the period. 


\section{Records of the Old Charlton Hunt}

\section{PRINCE RUPER'T'S RECEIPT FOR THE BITE OF A MAD DOG.}

A Large handfull of Rue, A Handfull of Red Sage, A Handfull of Ground Liverwort, two Heap'd Spoonfulls of Scrap'd Pewter, six heads of Garlick, one pound of Venice Treacle or Mithridate, three quarts of Strong Ale.

Put all into a well glaz'd Earthen Pot, stop the Pot very Close with Paste, set it over the Fire, and as soon as it has boyld, Take the Pot off the Fire, and set it to Infuse, by a Gentle Heat, for 24 hours, then press it, and strain it off for use.

To a Man give 5 Spoonfulls, Morning \& Evening, for 3 days, and repeat it att the next Full \& New Moon. The same quantity once a Day to a Dog.

Dress the Wound with old Mithridate.

\section{DR. MEAD'S RECEIPT FOR THE BITE OF A MAD DOG}

Lychen cinereus terrestris half an ounce, Black Pepper two drams.

Make this into four doses.

To be taken every morning fasting for four mornings in half a pint of Cows' Milk Warm.

The Patient must go into a Cold Bath every morning fasting for A Month. Then three times a Week for a fortnight. He must be dipt all over, and not keep his head above water more than half a minute. 


\section{CHAP'TER XIII ICHABOD!}

AND now, my reader, Charlton slumbers once again, almost as profoundly as it did long, long ago, before the advent of old Squire Roper and his pack marked the commencement of half a century of prosperity for the little hamlet such as it will never see again.

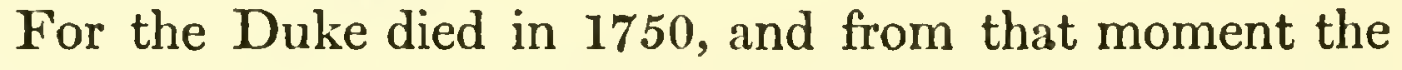
sun of Charlton commenced to set. 'Tis true, for many years the Hunt flourished exceedingly, for the new Duke transferred the headquarters to Goodwood, where the hounds found quarters far more palatial than the queer little oldfashioned kennels which they had been accustomed to in the old village over the hill, but-the old glory had departed !

The changes and chances of this mortal life (and possibly increased facilities for fox-hunting in other parts of the kingdom) scattered far and wide the brilliant throng whose names recur throughout these pages. They came no more to Charlton.

Quiet reigns over the valley now. No longer does 174 


\section{Records of the Old Charlton Hunt}

Levin Down witness those early morning scenes of bustle and animation that centred around the Duke's hunting-box, that sole survivor of so many; nor do the villagers gather o' nights around Foxhall to listen delightedly to the sounds of revelry with which the gentlemen of Charlton were wont to celebrate the close of each good hunting day. But the glamour of it all clings to the place still !

And so, dear reader, in tracing the fortunes of the Hunt, I have not cared to ask you to follow me beyond the quiet little valley that lies snugly beneath the shelter of the old Forest that my ancestor loved so well, and I can only hope that you may find it possible to share with me, in spirit at any rate, the fascination to which every sportsman must surely feel himself subject when brought in contact with old records of this description.

And now that my congenial task is done, the following verses, written years ago by poor Adam Lindsay Gordon, strike me with a sense of appropriateness as a conclusion :-

We have no wish to exaggerate

The worth of the Sports we prize,

Some toil for their Church, and some for their State,

And some for their Merchandise;

Some traffic and trade in the city's mart,

Some travel by land and sea,

Some follow science, some cleave to art,

And some to scandal and tea;

And some for their country and their Queen

Would fight, if a chance they had.

Good sooth, 'twere a sorry world, I ween,

If we all went galloping mad; 


\section{Records of the Old Charlton Hunt}

Yet if once we efface the joys of the chase

From the land, and outroot the stud, Good-bye to the Anglo-Saxon Race! Farewell to the Norman Blood!

And so

To all lovers of Fox-hunting

Past, present, and to come,

I dedicate this book! 



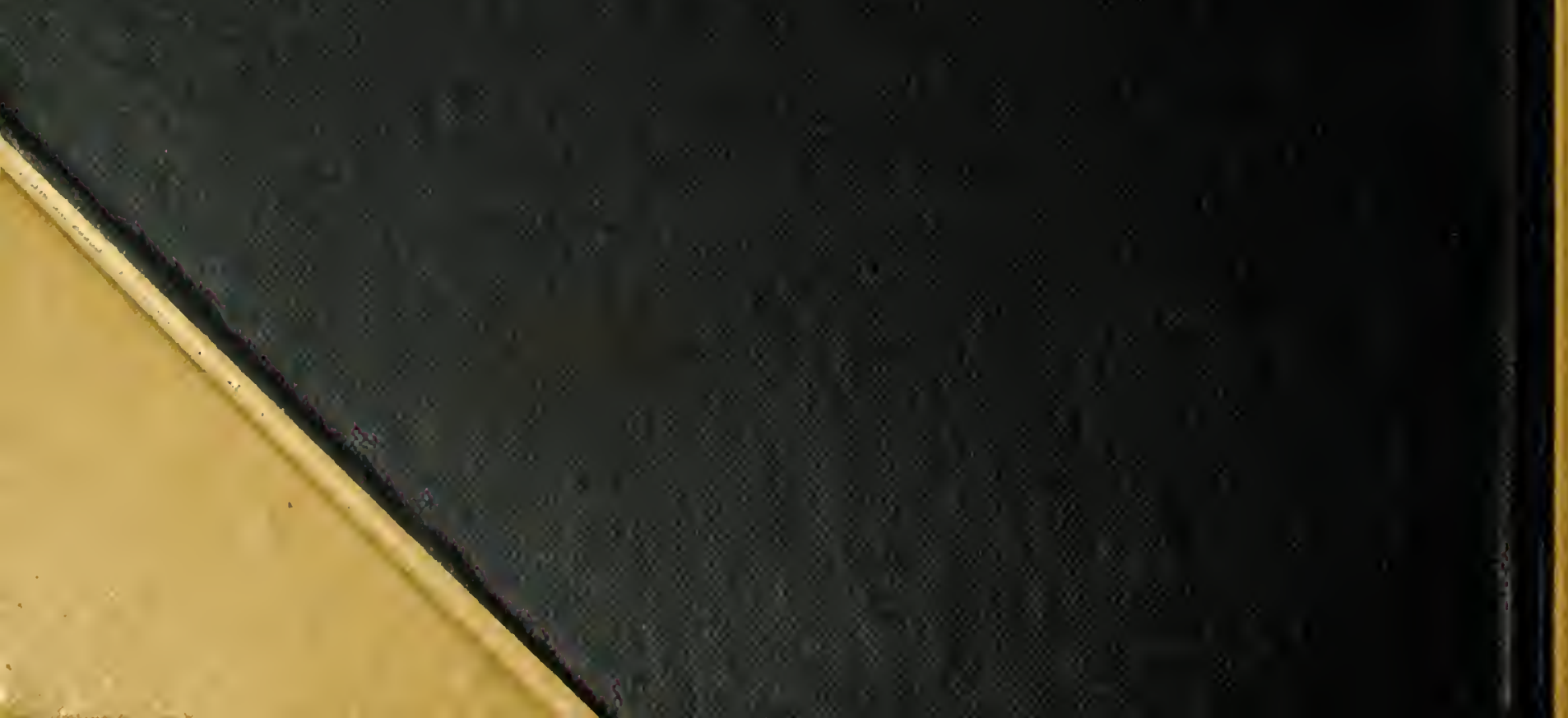

